\title{
Early hominins in Europe: The Galerian migration hypothesis
}

\author{
Giovanni Muttoni ${ }^{\text {a, *, Giancarlo Scardia }}{ }^{\text {b }}$, Dennis V. Kent ${ }^{\text {c, d }}$ \\ a Dipartimento di Scienze della Terra 'Ardito Desio', University of Milan, via Mangiagalli 34, I-20133 Milan, Italy \\ ${ }^{\mathrm{b}}$ Universidade Estadual Paulista, Instituto de Geociências e Ciências Exatas, 13506-900 Rio Claro, SP, Brazil \\ ${ }^{c}$ Department of Earth and Planetary Sciences, Rutgers University, Piscataway, NJ 08854, USA \\ d Lamont-Doherty Earth Observatory of Columbia University, Palisades, NY 10964, USA
}

\section{A R T I C L E I N F O}

\section{Article history:}

Received 27 June 2017

Received in revised form

20 October 2017

Accepted 21 October 2017

\section{Keywords:}

Early Pleistocene

Hominins

Galerian mammals

Europe

Migrations

\begin{abstract}
A B S T R A C T
Our updated review of sites bearing hominin remains and/or tools from Europe, including new findings from the Balkans, still indicates that the only compelling evidence of main hominin presence in these regions was only since $\sim 0.9$ million years ago (Ma), bracketed by the end of the Jaramillo geomagnetic polarity subchron $(0.99 \mathrm{Ma})$ and the Brunhes-Matuyama polarity chron boundary $(0.78 \mathrm{Ma})$. This time window straddled the late Early Pleistocene climate transition (EPT) at the onset of enhanced glacial/ interglacial activity that reverberated worldwide. Europe may have become initially populated during the EPT when, possibly for the first time in the Pleistocene, vast and exploitable ecosystems were generated along the eustatically emergent Po-Danube terrestrial conduit. These newly formed settings, characterized by stable terrestrial lowlands with open grasslands and reduced woody cover especially during glacial/interglacial transitions, are regarded as optimal ecosystems for several large Galerian immigrant mammals such as African and Asian megaherbivores, possibly linked with hominins in a common food web, to expand into en route to Europe. The question of when hominins first arrived in Europe thus places the issue in the context of changes in climate, paleogeography and faunal associations as potential environmental drivers and controlling agents in a specific time frame, a key feature of the Galerian migration hypothesis.
\end{abstract}

๑) 2017 Elsevier Ltd. All rights reserved.

\section{Introduction}

There is abundant evidence that shows earliest hominin colonization of Europe (Fig. 1) occurred sometime during the Early Pleistocene (e.g., Carbonell et al., 1995), but debate exists about its precise timing, even whether much earlier (e.g., Carbonell et al., 2008) or just later than 1 Ma (Muttoni et al., 2010, 2014; 2015a). The conundrum arises from the different methods that have been routinely applied to date key sites bearing hominin remains and/or lithic tools. Some methods are based on repeated empirical measurements of rock properties that are expressed as statistical means and associated error estimates (e.g., magnetostratigraphy, radiochronology, electron spin resonance, etc.), whereas others are based on comparative analyses of morphological fossil features aimed at assessing the degree of differentiation or evolution relative to other species or a common ancestor (biostratigraphy, vole clock). Each method is based on its own assumptions (often

\footnotetext{
* Corresponding author.

E-mail address: giovanni.muttoni1@unimi.it (G. Muttoni).
}

entombed in technical notes of scarce readability) and has its own advantages and limitations, providing data at different resolution and acceptance levels. The question of when hominins first arrived in Europe may however not be entirely answered by generating new age data. This is because the amount of chronological information that continental sediments may provide is ultimately limited and it becomes a matter of subjective taste to differentiate between 'good' and 'bad' data. We anticipate that the question may instead be tackled by finding meaningful trait d'union between the chronology of earliest hominin presence in Europe and the surrounding changing environment, geography and associated biota in which it occurred. A testable hypothesis with specific predictions that can subject it to refutation would be desirable and has been a key objective in our framing of the Galerian migration scenario.

\subsection{Quaternary dating methods: a short critical overview}

Magnetostratigraphy, which consists of retrieving the sequence of Earth's magnetic polarity reversals registered in rocks by magnetic minerals acting as natural compasses (Langereis et al., 2010), 


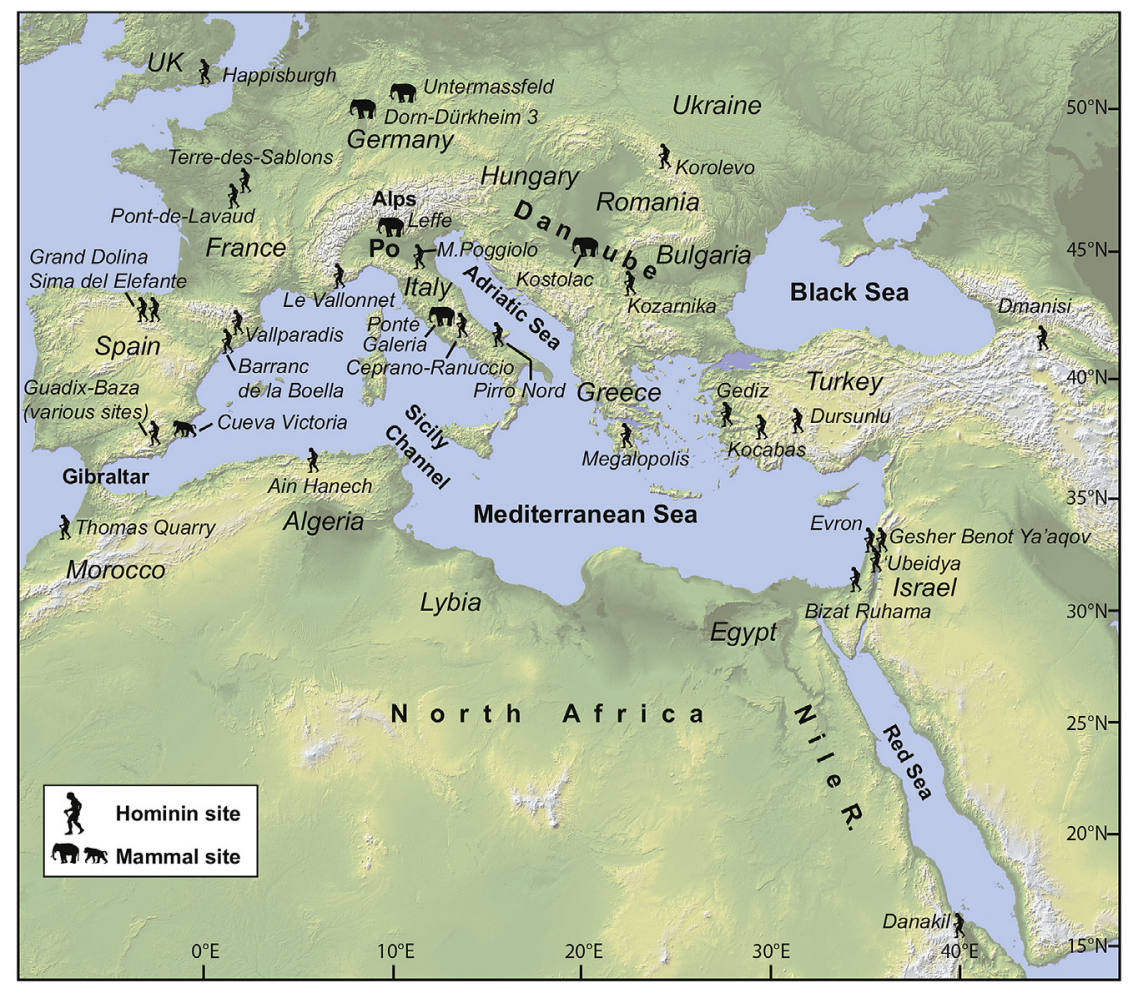

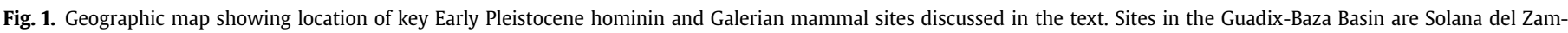

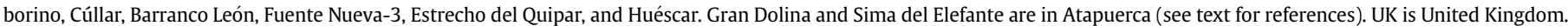

represents one of the most commonly used dating methods in Quaternary continental stratigraphy since the pioneering work of Kukla (1970). The sequence of geomagnetic polarity reversals (Fig. 2), calibrated by radioisotopic (e.g., ${ }^{40} \mathrm{Ar} /{ }^{39} \mathrm{Ar}$ ) and astrochronologic methods, serves as a central thread of modern astrochronological polarity time scales (APTS, e.g. Lourens et al., 2005; which is used here throughout) that in turn provide the chronological template for marine (e.g., Berggren et al., 1995) and continental (e.g., Gliozzi et al., 1997) biostratigraphies, and global climate variability (e.g., Lisiecki and Raymo, 2005). Key magnetostratigraphic ages (expressed in mega-annus or million years ago, Ma; Aubry et al., 2009) for the entire Pleistocene (= Quaternary; Pillans and Naish, 2004; Gibbard et al., 2010) and relevant to this discussion are listed here (ages rounded to nearest 0.01 Ma except the very short Cobb Mt.) from Lourens et al. (2005) and shown in Fig. 2.

- Brunhes-Matuyama boundary (beginning of $\mathrm{C} 1 \mathrm{n}$ ) $=0.78 \mathrm{Ma}$

- Matuyama-Jaramillo boundary (beginning of C1r.1r) = $0.99 \mathrm{Ma}$

- Jaramillo-Matuyama boundary (beginning of C1r.1n) = 1.07 Ma

- Matuyama-Cobb Mountain boundary (beginning of C1r.2r) = $1.173 \mathrm{Ma}$

- Cobb Mountain-Matuyama boundary (beginning of C1r.2n) = $1.185 \mathrm{Ma}$

- Matuyama-Olduvai boundary (beginning of C1r.3r) = $1.78 \mathrm{Ma}$

- Olduvai-Matuyama boundary (beginning of $\mathrm{C} 2 \mathrm{n}$ ) = $1.95 \mathrm{Ma}$

- Matuyama-Gauss boundary (beginning of C2r) $=2.58 \mathrm{Ma}$

Operatively, magnetostratigraphy offers the distinct advantage of being potentially applicable to a wide variety of depositional systems, ranging in the continental environment from lacustrine to fluvial, glacial and eolian (loess), as well as soils and cave infills. However, because magnetostratigraphy provides indirect numerical age estimates by means of correlations to a reference APTS, limitations may arise when the stratigraphic (time) coverage of a sampled section is insufficiently constrained to identify a diagnostic sequence of polarity reversals. For example, reverse polarity magnetizations are extremely valuable in showing that the hosting sediments are most probably older than $0.78 \mathrm{Ma}$, which is the age of the Brunhes-Matuyama boundary that corresponds to the Early-Middle Pleistocene boundary (Head et al., 2008), but additional information is required to assess how long before this datum the magnetization was acquired. There is also evidence of several magnetic polarity excursions of only a few kiloyear duration each, such as the Laschamp at $41 \mathrm{ka}$ (kilo-annus or thousand years ago), Blake at $120 \mathrm{ka}$, Iceland Basin at $188 \mathrm{ka}$, Pringle Falls at $211 \mathrm{ka}$, Big Lost at 560-580 ka, Stage 17 at 690 ka, Kamikatsura and Santa Rosa at around 899 and $936 \mathrm{ka}$ (Laj and Channell, 2015). These very short polarity features offer the potential of high-resolution stratigraphy, but mostly in continuous marine environments that are provided with records of orbital cyclicity or stable isotope variability. Conversely, in continental sediments polarity excursions are in general elusive and yet are sometimes called upon to explain artifacts of noisy records.

Radioisotopic dating, such as ${ }^{40} \mathrm{Ar} /{ }^{39} \mathrm{Ar}$, can provide direct and increasingly more precise numerical age control but only when suitable and fresh (unaltered) volcanic layers happen to be embedded in the stratigraphic sequence, a relatively rare situation encountered only in particular geologic settings and depositional systems such as fluvial or lacustrine successions in volcanic areas (e.g., Morgan et al., 2012). The more recently developed electron spin resonance (ESR) and cosmogenic burial or exposure dating techniques (e.g., ${ }^{26} \mathrm{Al}$ and ${ }^{10} \mathrm{Be}$ ) offer the advantage of being applicable to very commonly encountered materials in continental deposits such as quartz grains, but they rely on assumptions about the pre- and post-burial history of the sediments and nuclide dosages that are not always easy to assess (e.g., Granger, 2006). In that 


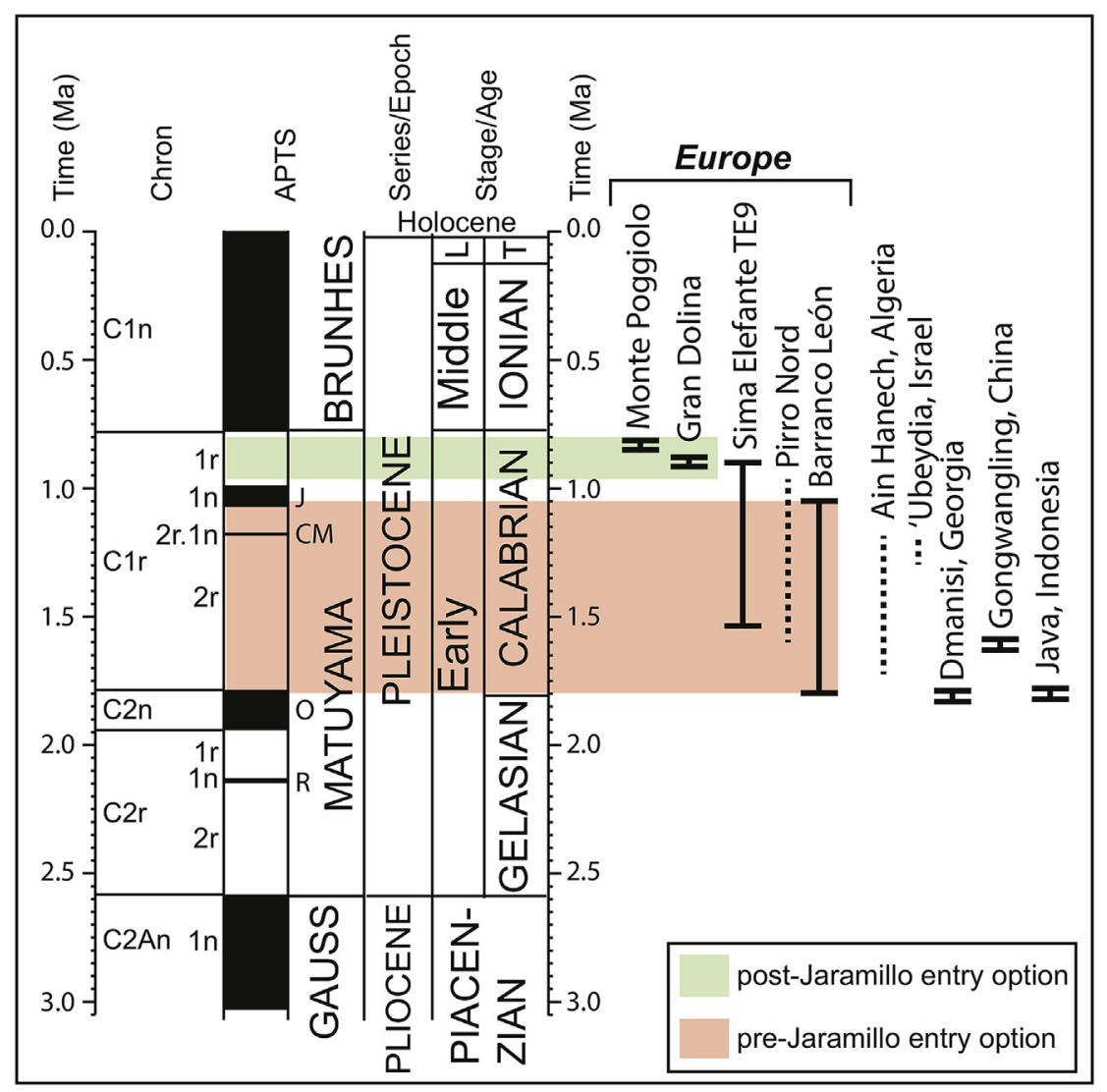

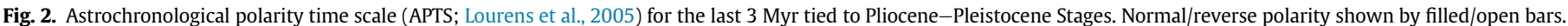

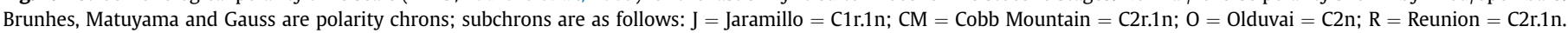

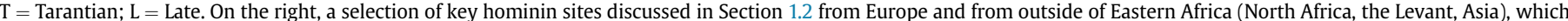

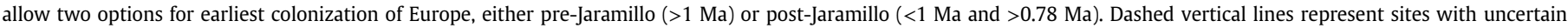
chronology. The migration hypothesis discussed in this paper is consistent with the pre-Jaramillo option.

respect, cosmogenic and ESR dating methods may not (yet) be suitable as stand-alone dating tools, as illustrated in the recent debates concerning the cosmogenic burial ages of the Sima del Elefante (Atapuerca) hominin site (Carbonell et al., 2008), which are associated with large formal uncertainties of up to $600 \mathrm{kyr}$ (at $2 \sigma$ level), or the ESR age of the Barranco León hominin site, with a doubtfully sufficient resetting of the ESR clock prior to deposition (Muttoni et al., 2013 vs. Toro-Moyano et al., 2013) (see discussion in Sections 6.2 .9 and 6.2.10, respectively).

As for biochronology, it should be understood that the relative timing of key Villafranchian and Galerian mammal associations or faunal units that characterized the Italian peninsula (e.g., Gliozzi et al., 1997; Masini and Sala, 2007) and France (e.g., Nomade et al., 2014) is based upon paleontological localities very few of which are provided with direct chronologic (radiometric and/or magnetostratigraphic) constraints. In France, it has been possible to constrain precisely some important Pliocene to Early Pleistocene sites by ${ }^{40} \mathrm{Ar} /{ }^{39} \mathrm{Ar}$ geochronology because of volcanic activity in the Central Massif (Nomade et al., 2014). In Italy, volcanic deposits are mostly documented from the Middle and Late Pleistocene and thus magnetostratigraphy is practically the only suitable tool to date Early Pleistocene fossil faunal localities. Up to now, the only Pleistocene faunal unit in Italy provided with a modern ${ }^{40} \mathrm{Ar} /{ }^{39} \mathrm{Ar}$ age determination is the Isernia faunal unit from the Isernia La Pineta Lower Paleolithic site dated to 583-561 ka (Peretto et al., 2015; see also Coltorti et al., 2005). Otherwise, Italian faunal units in biostratigraphic reference scales (e.g., Gliozzi et al., 1997) from the
Olduvai subchron to the Brunhes-Matuyama boundary are scarcely constrained in age as, for example, the Pirro Nord hominin site from southern Italy, presently one of the oldest claimed sites in Europe with a proposed age of 1.6-1.3 Ma based essentially on biostratigraphic arguments (Pavia et al., 2012) (see discussion in Section 6.2.6). What is nonetheless of importance is being able to firmly associate scarce hominin levels to more common occurrences of representative faunal units that can serve as proxies of, and give broader clues about, the ecological context of hominin migrations.

\subsection{Early hominins in Europe: current options}

In spite of the uncertainties outlined above, we can confidently assert that the earliest hominin occupation of Europe started prior to the 0.78 Ma Brunhes-Matuyama boundary. This is based on studies conducted using magnetostratigraphy as a prime dating method at hominin sites in Spain (Gran Dolina, Atapuerca: Parés and Perez-González, 1995, 1999; Parés et al., 2013; Sima del Elefante, Atapuerca: Parés et al., 2006; Carbonell et al., 2008; Guadix Baza Basin: Gibert et al., 2007; Scott and Gibert, 2009; Vallparadís: Martínez et al., 2010; Madurell-Malapeira et al., 2010, but see Madurell-Malapeira et al., 2012 vs. García et al., 2012 for origin of lithic tools), Italy (Monte Poggiolo: Muttoni et al., 2011; Pirro Nord: Pavia et al., 2012; but see Section 6.2.6), and England, U.K. (Happisburgh 3: Parfitt et al., 2010). (for sites locations see Fig. 1). Taking into account the ongoing issues concerning the ages of some of these and other sites, as discussed below, the debate about the 
earliest entry of hominins in Europe during the Matuyama Chron can be reduced to two hypotheses: a post-Jaramillo-and-preBrunhes option (0.99-0.78 Ma), as exemplified by sites like Gran Dolina, and Monte Poggiolo, and a Jaramillo or earlier ( $\geq 0.99 \mathrm{Ma}$ ) option, as proposed from sites like Sima del Elefante, Pirro Nord, and Barranco León in the Guadix-Baza Basin (Fig. 2).

We argue below that the best evidence supports the view that the earliest main peopling occurred according to the postJaramillo-and-pre-Brunhes option. This option implies however a noticeable age gap approaching 1 Myr with the oldest claimed hominin sites elsewhere outside of Eastern Africa (Fig. 1), where Homo erectus/ergaster first appeared as early as 1.9 Ma (e.g., Antón et al., 2014), such as Aïn Hanech in Algeria ( 1.7-1.2 Ma; Geraads, 2010; Parés et al., 2014; see discussion in Chapter 5), 'Ubeidiya in Israel ( 1.3-1.2 Ma; Rink et al., 2007), Dmanisi in Georgia ( 1.85-1.78 Ma; Ferring et al., 2011), Gongwangling in China ( 1.62 Ma; Zhu et al., 2015), and Java in Indonesia ( 1.8 Ma; Swisher et al., 1994) (Fig. 2). It is possible that this age gap is an artifact of the limited European archeological inventory. Alternatively, if the observed time gap is real, as we are disposed to believe, the environmental drivers that retarded the entry in Europe of hominins that already exited Africa in the Early Pleistocene would need to be elaborated upon. This is what we attempt to describe now.

\section{The Galerian migration hypothesis: an integrated chrono- ecologic approach}

Human migrations were surely influenced by environmental factors (Leroy et al., 2011; Cuenca-Bescós et al., 2011; Timmermann and Friedrich, 2016), and considering the extreme variability of Pleistocene global climate, the timing of human migration should be viewed together with the environmental and ecological context in which it occurred.

Pleistocene global climate variability is well known from marine benthic oxygen isotope records that have been time-calibrated with magnetostratigraphy and tuned according to astronomical cyclicity with great accuracy (within $40 \mathrm{kyr}$ ) and resolution (<10 kyr) (Shackleton and Opdyke, 1976; Shackleton, 1995; Lourens et al., 2005; Lisiecki and Raymo, 2005). These records, e.g., the ODP677 benthic oxygen isotope record of Shackleton et al. (1990), reveal the presence of a major climate transition (or revolution) centered at $\sim 0.9 \mathrm{Ma}$ after the Jaramillo subchron and before the Brunhes Chron (e.g., Berger et al., 1993), hereafter termed EPT (for late Early Pleistocene Transition). Reverberations of the EPT at regional and local scales are reflected, for example, in pollen records that reveal vegetational oscillations from closed forests to steppe and grasslands during glacial-interglacial cycles (e.g., Tzedakis et al., 2006). The development of Pleistocene mammal biostratigraphy and biochronology (e.g., Gliozzi et al., 1997), although still subject to substantial age uncertainties (Muttoni et al., 2010, 2014; this study), has the merit of bringing into the climatic-environmental narrative relevant information about faunal turnovers, such as the Villafranchian-Galerian transition (e.g., Azzaroli, 1983), that may provide clues to understanding the dynamics of hominin migrations relative to other species and the food web they may have shared.

We choose to address the earliest peopling of Europe with a critical re-assessment of the age data of key hominin sites combined with an integration of this chronology into the flow of recent information concerning the evolution of climate, fauna, flora, sea level changes, and geomorphology in critical areas of Europe, such as the Po and Danube plains, that may have acted as important migration gateways connecting eastern with western Europe during the late Early Pleistocene. Our survey is focused primarily on the earliest available Quaternary sites with interesting mammalian fossil records, not just of hominins, and provided with well- described magnetostratigraphies and specific correlations to the APTS. We also discuss sites dated with relatively new types of exposure dating (see a critical review by Ludwig and Renne, 2000).

Based on this body of knowledge, we formulate a testable hypothesis on the timing, pathways, and potential environmental causes of mammal and hominin immigration to Europe that is consistent with (or at least not contradicted by) what we would regard as the best-dated archeological records from the literature. What we refer to as the Galerian migration hypothesis (formerly 'follow-the-herd' hypothesis [Muttoni et al., 2010] and 'migratewith-the-herd' hypothesis [Muttoni et al., 2014]), holds, in simple terms, that early hominins entered Europe after the Jaramillo, at ca. $0.9 \mathrm{Ma}$, in conjunction with fellow mammal immigrants from Africa and Asia that became the Galerian terrestrial fauna of major mammals. This influx developed as a consequence of a profound rejuvenation of the ecosystems resulting from the opening of an ecologically sustainable continental migration conduit across the conjunct Po-Danube plains during the EPT. We review the development and paleobiogeographic basis of the Galerian migration hypothesis starting with the development of our understanding of the evolution of the Po Plain.

\section{Origin of the Galerian migration hypothesis: the Po plain stratigraphic and climatic record}

\subsection{The ' $R$ surface'}

The origin of the Galerian migration hypothesis is intimately linked with our understanding of the evolution of the Po Plain (Fig. 3), which became a stable terrestrial conduit, fully exploitable for mammal migrations, only since the end of the Early Pleistocene. The initial analysis (Muttoni et al., 2003) of a 200 m-long drill core (Pianengo RL2 core) showed the presence of a stratigraphic boundary (Fig. 4, red line) that was well known to petroleum geologists to extend across virtually the entire Po Plain subsurface as a prominent seismic reflector termed the ' $R$ surface' ( $R=$ red, from the ENI color code for seismic interpretation). It separates levels below characterized by sedimentary facies attributed to lowenergy meandering rivers flowing onto lower-energy alluvial plains with occasional marine incursions, from levels above attributed to high-energy braided stream systems with no evidence of marine deposition (Fig. 4A). Sandstone petrographic data documented that the pre-unconformity rivers were sourced in the Central and Western Alps, more than one hundred kilometers away from the Po Plain at Pianengo, whereas the post-unconformity rivers were sourced in the more proximal Southern Alps, located a few tens kilometers to the north of Pianengo (Fig. 4B). Pollen data indicated that pre-unconformity climate oscillated repeatedly between warm and cool - but never cold and arid - conditions while pollen recovered in sediments immediately above the unconformity indicated a pronounced shift towards cold, arid and steppic conditions (Muttoni et al., 2003) (Fig. 4C). This distinctive climatedriven pollen signature was recovered also in the Leffe core located a few kilometers north of Pianengo in the Southern Alps (Muttoni et al., 2007; see below). At Pianengo, the ' $R$ surface' was constrained by magnetostratigraphy to occur between the top of the Jaramillo (0.99 Ma) and the base of the Brunhes (0.78 Ma) (Fig. 4D and $\mathrm{E})$.

According to the derived age model of sedimentation (Fig. 4F), the ' $R$ surface' was associated with the sea level falling phase of Marine Isotope Stage (MIS) 22 at $\sim 0.9 \mathrm{Ma}$, which stands out since the work of Shackleton and Opdyke (1976) as representing the first major ice volume-induced sea level decrease of the Pleistocene. Before MIS 22, glacio-eustatic oscillations were of low amplitude and high frequency ( 1/41 kyr) compared to the higher amplitude 


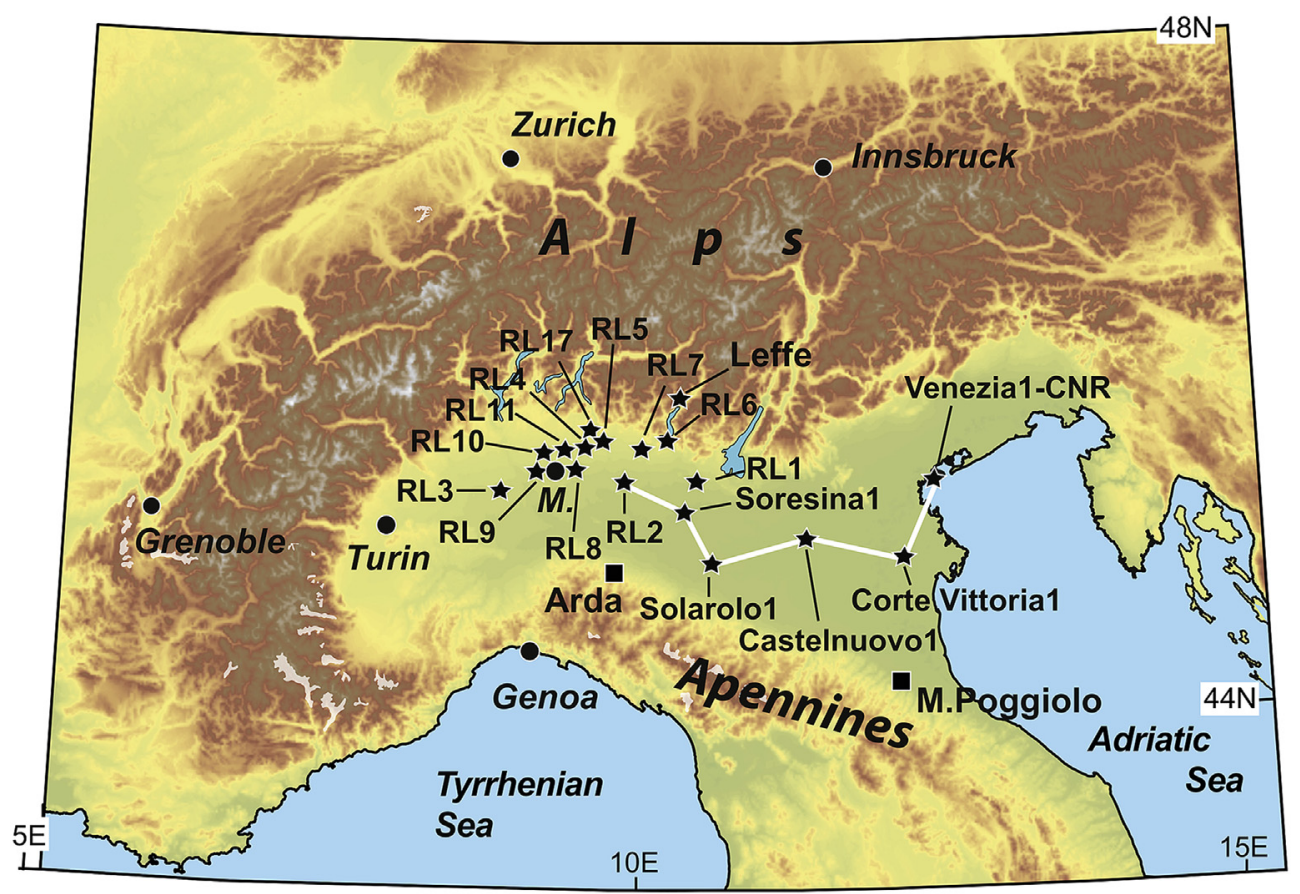

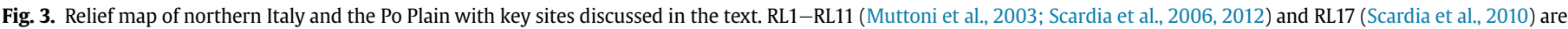

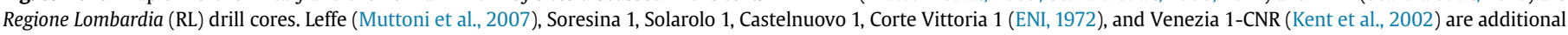

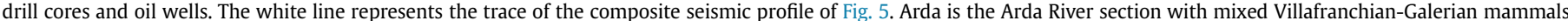

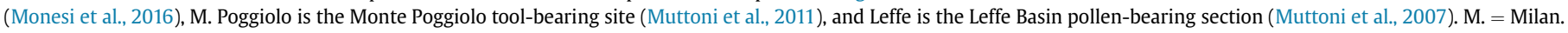

and lower frequency $(\sim 1 / 100 \mathrm{kyr})$ oscillations typical of the Pleistocene since MIS 22; this marked transition in global climate variability represents the EPT (Shackleton and Opdyke, 1976; Berger et al., 1993; Shackleton, 1995; Lisiecki and Raymo, 2005; Head and Gibbard, 2005; Hodell and Channell, 2016).

During the pronounced sea level falling stage, forced regression prompted high-energy braided stream systems sourced in the nearby Southern Alps to rapidly prograde for the first time over the moderately subsiding Po basin margin. The impedance contrast associated with the abrupt superposition of such different depositional systems produced the 'R surface' horizon in seismic profiles (Fig. 5). Above the ' $\mathrm{R}$ surface', other laterally continuous seismic reflectors mark the progradation of additional high-energy sedimentary packages related to the other pronounced sea level falls of the Middle Pleistocene at least up to MIS12 at $0.45 \mathrm{Ma}$ when another major seismic horizon known as the ' $\mathrm{Y}$ surface' ( $Y=$ yellow) formed (Fig. 5) (Scardia et al., 2012; see also below).

A second line of evidence supporting MIS 22 as marking a major climatic and environmental turnover was obtained by applying magnetostratigraphy and subordinately mammal biostratigraphy to date climate sensitive pollen cycles and lithostratigraphic units recorded in a $189 \mathrm{~m}$-long core and additional exposed sections that cut through the Pliocene-Pleistocene Leffe sedimentary succession from the Southern Alps a few tens kilometers north of Pianengo (Muttoni et al., 2007) (Fig. 3). This study revealed that a main phase of lacustrine deposition at Leffe, represented by the Leffe Formation, was sharply overlain by gravels attributed to a high-energy braided river system fed by local alluvial fans pertaining to the Gandino Formation (Fig. 6A). Pollen analysis revealed that, as at Pianengo, climate varied cyclically from warm-temperate to cool during times of lake deposition, whereas the superjacent highenergy sediments were deposited during cold and arid (glacial) conditions (Fig. 6B). The age model of sedimentation developed using magnetostratigraphy highlighted that lacustrine deposition
(Leffe Formation) started during the Olduvai subchron, continued across the Jaramillo subchron and terminated at a level of reverse polarity predating the base of the Brunhes (which was not found at Leffe) (Fig. 6C and D). Similarly to Pianengo, the deposition of highenergy sediments of cold climate (Gandino Formation) occurred at MIS 22 times and was preceded during the MIS 22 forced regression by the formation of the 'R surface' (Fig. 6, red line).

The Pianengo and Leffe scenarios described above were linked in a common stratigraphic network along a same fluviatile system - the Serio River - sourced in the Southern Alps and flowing southward into the Po Plain (Muttoni et al., 2007) (Fig. 7). Immediately above the ' $R$ surface', gravels of cold climate prograded from the Serio River catchment area over the Leffe Basin and toward the Po Plain in response to the generalized event of vegetation withdrawal and enhanced physical erosion compatible in age with MIS 22 at $\sim 0.9$ Ma. This was when Alpine valley glaciers reached their first maximum southward expansion with glacier fronts located only $\sim 5 \mathrm{~km}$ upstream from Leffe (Muttoni et al., 2007) (Fig. 3).

Farther east in the Adriatic Sea, the 950 m-deep core Venezia 1CNR from Venice (Fig. 3) was studied for magnetostratigraphy and biostratigraphy to document the Pliocene-Pleistocene paleoenvironmental evolution of the Po Plain in a more distal, marine setting (Kent et al., 2002; Massari et al., 2004) (Fig. 8). After the regional drowning of a late Pliocene shelf associated with the northward migration of the Apeninne front (Ghielmi et al., 2010; Scardia et al., 2015), the Venice area recorded a prolonged ( 1 Myr) stage of sediment starvation that ended with the onset of a massive turbiditic input in the Matuyama Chron between the highest occurrence of the nannofossil Large Gephyrocapsa $(\geq 1.25$ Ma; Backman et al., 2012) and the lowest occurrence of Gephyrocapsa sp. 3 ( $\leq 0.97$; Lourens et al., 2005). This major shift in style of sedimentation occurs at a level correlated to the 'R surface' (Scardia et al., 2010).

We use data from all available magnetostratigraphically dated 


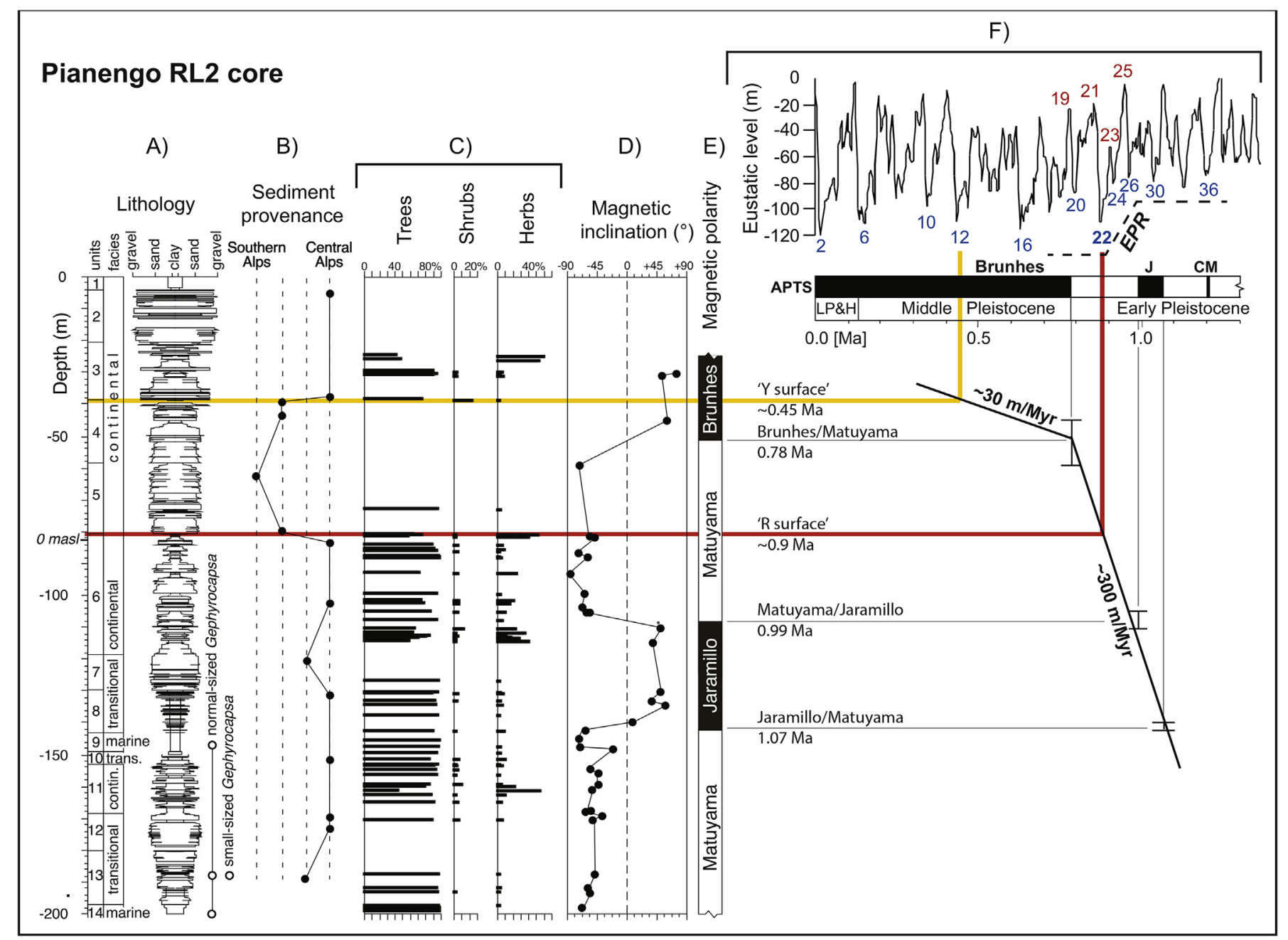

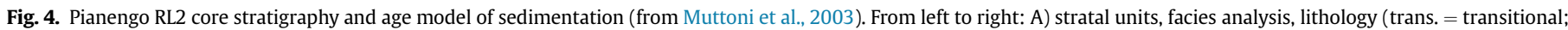

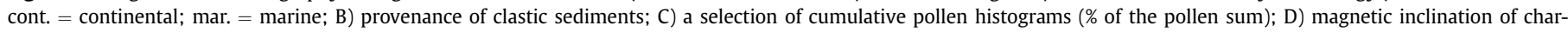

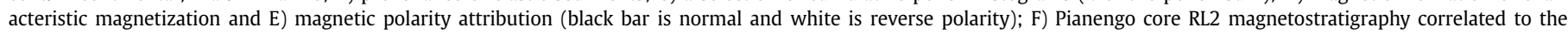

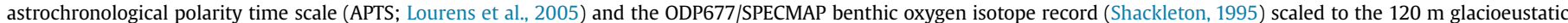

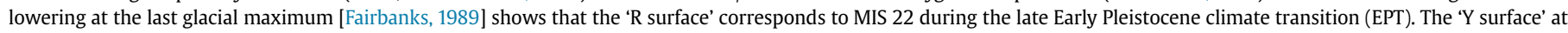
$\sim 0.45 \mathrm{Ma}$ is also shown. $\mathrm{J}=$ Jaramillo; $\mathrm{CM}=$ Cobb Mountain. $\mathrm{LP} \& \mathrm{H}=$ Late Pleistocene and Holocene.

drill cores from the central-northern Po Plain (RL1-RL11) (Muttoni et al., 2003; Scardia et al., 2006, 2012), as summarized in the stratigraphic correlation scheme of Fig. 9 (see Fig. 3 for geographic locations of cores), augmented by a composite seismic profile connecting the central Po Plain with the Adriatic Sea basin (Fig. 5), to provide further confirmation of the regional significance of the ' $R$ surface', which we trace in the Venice core at the onset of turbiditic sedimentation (Figs. 5 and 8). These turbidites are interpreted to be the far-field evidence of the climate-driven enhanced energy of the continental depositional systems during the pronounced cold stages starting with MIS 22. From this point on, enhanced erosion in the Alps produced by repeated glaciations led to the rapid infilling of the Po Plain basin as revealed by the marked eastward progradation of a shelf complex (Fig. 9). At Venice, sedimentation evolved into a shallowing-upward trend with the basinal turbidites overlain by delta deposits (Fig. 8). The first continental (fluvial) sediments are therein recorded at $\sim 0.45$ Ma during the MIS12 lowstand and are preceded by the formation of the 'Y surface' during the MIS 12 forced regression (see also Section 3.2).

As a corollary of these ' $R$ surface' and ' $Y$ surface' studies, it emerged that the Alps experienced a Pleistocene phase of moderate uplift of inferred isostatic origin probably triggered by glacial erosion and transfer of fluvioglacial sediments to the peripheral Po Plain since the onset of the major Pleistocene glaciations since $\sim 0.9$ Ma (Scardia et al., 2006, 2012).

\subsection{Timing of the marine-continental transition in the Po plain}

From the studies outlined above it emerged that the 'Y surface' marked the onset of full continentalization of the Po Plain. The timing of the transition from marine to continental sedimentation was studied along the Arda River section outcropping in the Apennine foothills at the southern margin of the Po Plain where it is particularly well exposed (Fig. 3). A clear magnetostratigraphic sequence comprising the Jaramillo subchron and the Brunhes-Matuyama boundary was developed in conjunction with oxygen isotope data from the literature to date the succession of sedimentary facies (Monesi et al., 2016) (Fig. 10). The age model of sedimentation derived from these data revealed that the progressive infill of the Po Plain driving the marine-continental transition started in the Jaramillo but was fully and permanently established only since MIS 22 (Fig. 10). In addition, data from the Arda section 


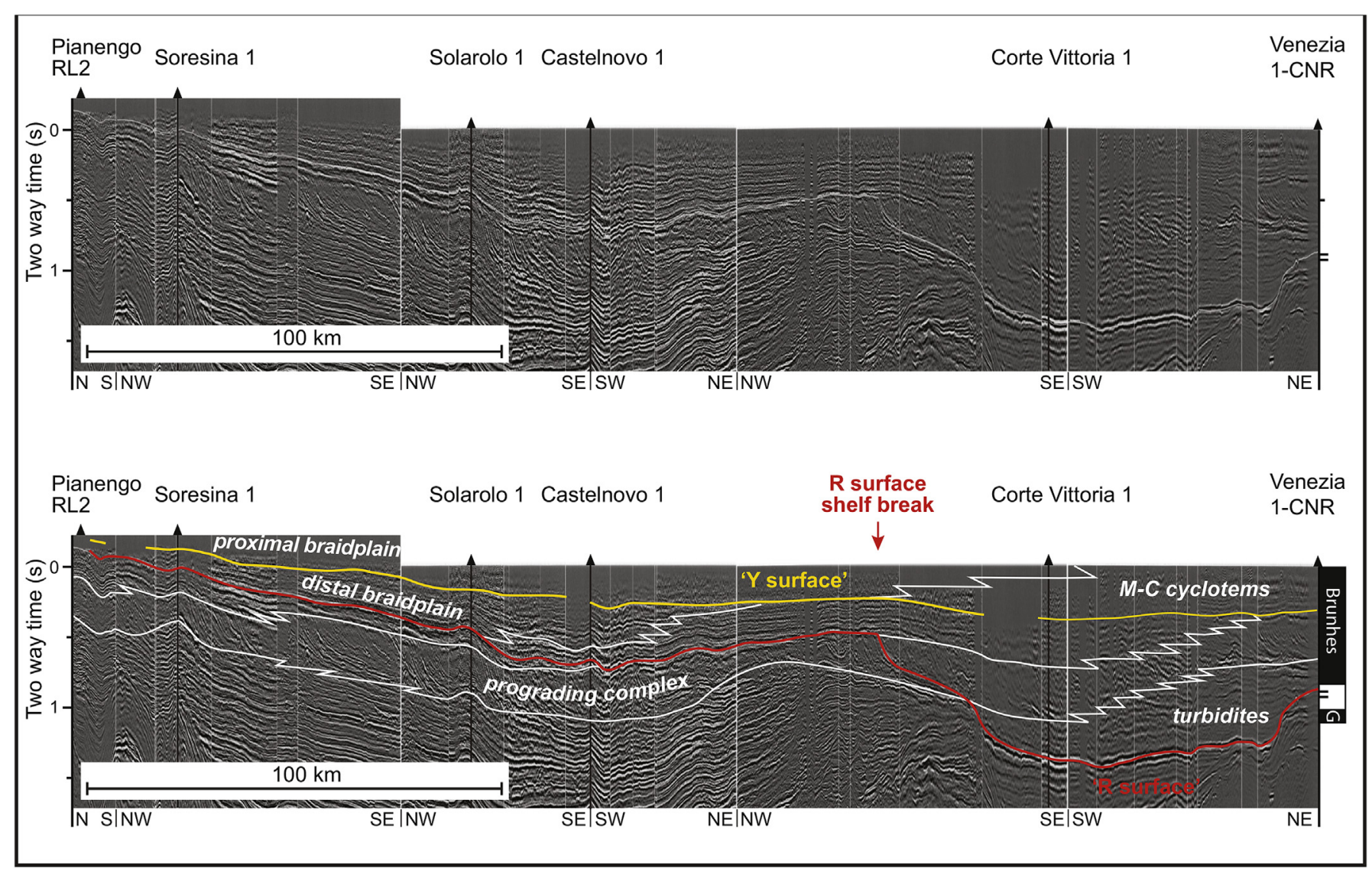

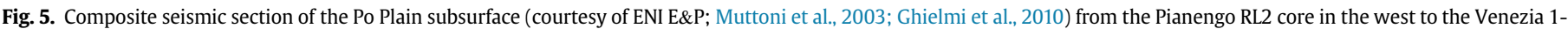

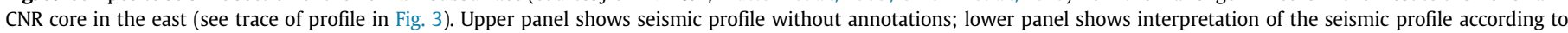
various depositional systems from below the ' $R$ surface' up to the ' $Y$ surface'. $M-C$ cyclothems = marine-continental cyclothems; $G=G a u s s$ Chron. See text for discussion.

used in conjunction with data from the coeval Enza River section (Gunderson et al., 2014) and the Monte Poggiolo composite section (Muttoni et al., 2011) allowed Monesi et al. (2016) to more finely resolve the timing of this marine-continental transition in the greater Po Plain. They found that the transition was somewhat diachronous: the first littoral sediments were already accumulating during MIS 30 within the Jaramillo in the Arda-Enza region whereas marine conditions persisted in the eastern part of the Po Plain at Monte Poggiolo in the early part of the post-Jaramillo Matuyama (Fig. 11A and B). A similar diachroneity was observed in previously studied deep cores from the northern part of the Po Plain (Scardia et al., 2006, 2012) (Fig. 11A and B).

A major jump eastward of the coastline (regression and continentalization) was first established along the entire $\sim 230 \mathrm{~km}$-long studied Po Plain transect only at the MIS 22 low-stand ( 0.9 Ma) and persisted during the ensuing MIS 22/MIS 21 sea level rise and even the MIS 21 high-stand at $\sim 0.85 \mathrm{Ma}$ (Fig. 11B).

\section{Developing the Galerian migration hypothesis}

\subsection{The opening of the Po-Danube conduit in the Late Matuyama}

The consequences of the Late Matuyama EPT on the ecosystems and hominin migration routes outside the Po Plain can be explored starting from Africa. Larrasoaña et al. (2013) established a link between Mediterranean sapropels, traditionally attributed to increased Nile runoff during Northern Hemisphere summer insolation maxima, and recurrent humid episodes in North Africa - the so-called Green Sahara Periods (GSPs) - with savanna-grassland expansions that may have favored mammal dispersion. The GSP record was shown to be relatively continuous throughout the Pliocene-Pleistocene (Larrasoaña et al., 2013) (Fig. 12A-C). The only apparent gap, characterized by three oxidized sapropels (and hence possible GSPs), ironically occurred during the EPT from $~ 0.9$ Ma to $\sim 0.7 \mathrm{Ma}$ (Fig. 12C). This timing coincides with a noticeable increase in Sahara dust production as revealed by data from ODP Site 967 (Larrasoaña et al., 2003; Trauth et al., 2009) (Fig. 12D). Since that time over the course of the Middle Pleistocene, there seems to be a correlation between dampening of dust production throughout the Sahara during periods of enhanced sapropel formation (Larrasoaña et al., 2013).

It thus appears that there were as many as 63 GSPs since $2 \mathrm{Ma}$ (Larrasoaña et al., 2013) during any of which hominins and other mammals could probably have crossed the Sahara region and migrated into the Levant to proceed to Southwest Asia (Ferring et al., 2011), China (Zhu et al., 2015), and Southeast Asia (Swisher et al., 1994). Nevertheless, according to our critical review in Chapter 6 of the chronology of European sites, it seems that the best-constrained window of main hominin colonization of Europe was during the EPT at around $0.9 \mathrm{Ma}$. We argue that this happened when a sustainable migration conduit for their expansion from staging areas at the Gates of Europe (e.g., Levant, Turkey) directly into Europe was generated for the first time in the Pleistocene. This conduit, formed by the conjunct Po Plain in northern Italy and the Danube Plain in Romania, Serbia and Hungary, opened when sealevel dropped and these river valleys became continental plains, 


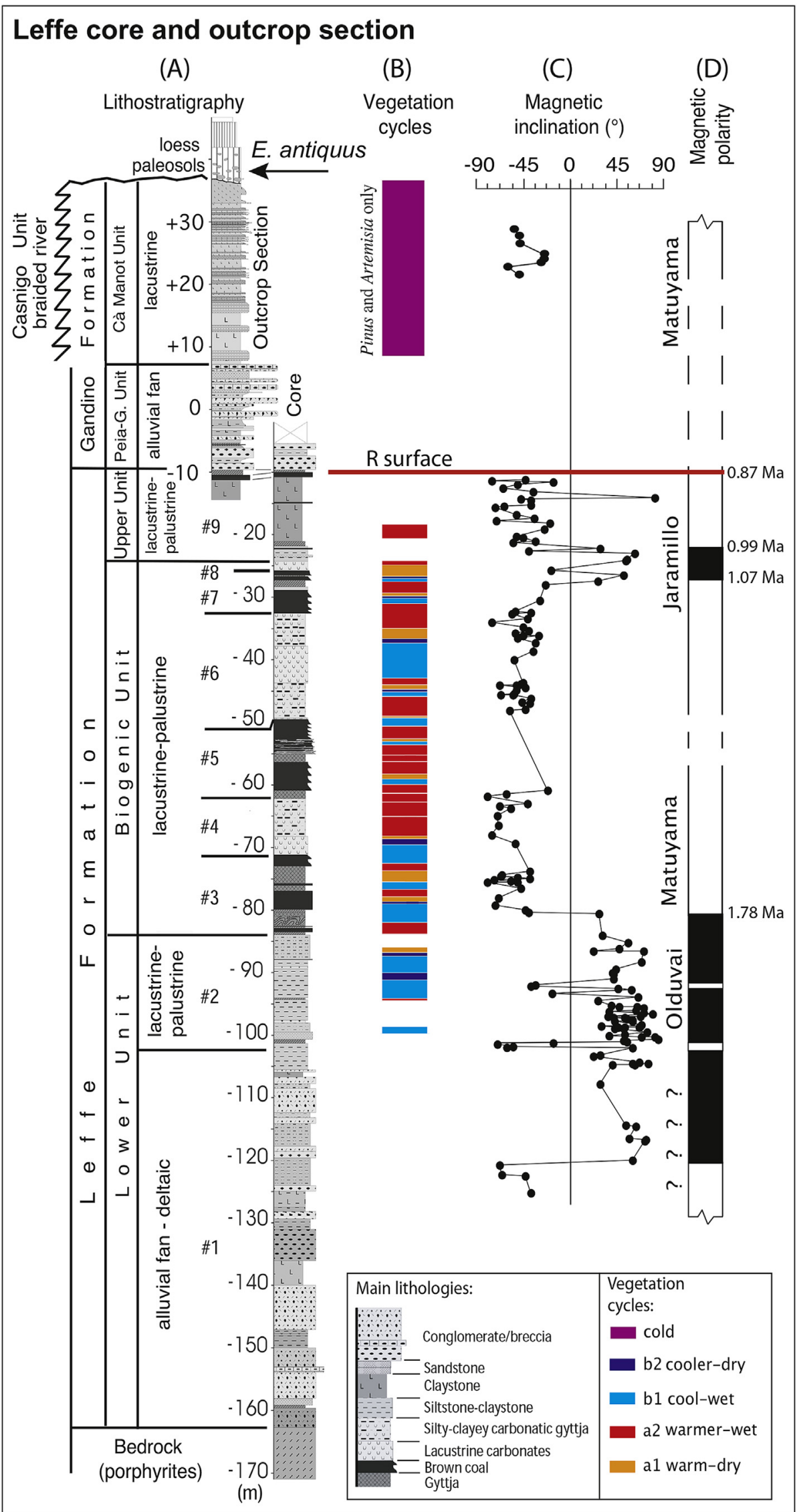


as documented by studies on the evolution of the Po Plain and the 'R surface' (see Chapter 3 ) as well as the available, albeit more limited, studies on the parallel evolution of the Danube Plain (Winguth et al., 2000; Gábris and Nádor, 2007). In particular, during pre-MIS 22 (>0.9 Ma) sea-level high-stands, the Po and Danube valleys were mostly flood plains inundated by the Adriatic Sea and Black Sea, respectively (Fig. 13A). Pollen data obtained from the magnetostratigraphically calibrated Pianengo RL2 and the Leffe cores described earlier (Muttoni et al., 2003, 2007; Ravazzi et al., 2005) and the record from Tenaghi Philippon in northern Greece (Tzedakis et al., 2006) (Fig. 12E) indicate that before MIS 22 and the EPT, climate was generally warm-temperate to cool with abundant closed forests characterized by deciduous broad-leaved species alternating with conifers. In these conditions, the Po-Danube conduit was presumably closed, at least to megaherbivores such as Mammuthus trogontherii and Elephas antiquus, which were mixed browsers-grazers and therefore more adapted to open grassland-reduced woody cover ecosystems that developed (intermittently) only since MIS 22 (see also Section 4.2) (Fig. 13A).

During MIS 22, climate cooled and became locally more arid, triggering forest withdrawal. The Tenaghi record shows clear evidence of high amplitude and low frequency oscillations with very pronounced expansions of steppe and grasslands during the main glacial phases starting with MIS 22 (Fig. 12E), in agreement with additional records from France (de Beaulieu et al., 2006, 2013) and Italy (Magri, 2010). At the MIS 22 low-stand ( 0.9 Ma), the PoDanube conduit became fully terrestrial and therefore potentially exploitable for migrations especially during the waning stages of MIS 22 (Fig. 13B). During the ensuing MIS 22/21 transition ( 0.85 $\mathrm{Ma})$, the Po-Danube terrestrial conduit was colonized by grassland vegetation and/or open forests of milder climate, which are considered optimum environments for dispersals of hominins (Leroy et al., 2011) (Fig. 13C) and megaherbivores like elephants (see also Section 4.2). These megaherbivores and other Galerian mammals that presumably exploited the Po-Danube conduit were not necessarily confined during migration to within the specific boundaries of the conduit. The dispersal dynamics and geometry probably varied greatly depending on the actual ecologic conditions encountered during translocation (Tchernov, 1992). What matters here is that the conduit was spatially anisotropic insofar as it followed WNW-directed river plains and thus had the probable effect of imposing a long-term $\left(\sim 10^{5} \mathrm{yr}\right)$ cumulative net direction to mammal expansion from the Gates of Europe into Europe; this was particularly so for herbivores that were already adapted to woody grasslands that developed intermittently along the conduit only since MIS 22 and the MIS22/21 transition.

\subsection{European entry of mammal immigrants from Africa and Asia}

The EPT is marked by a prominent faunal turnover, known as the 'Crocuta crocuta event', characterized by the entrance in Europe of far-traveled Galerian/Cromerian species from Africa and Asia that progressively replaced late Villafranchian (European resident) taxa (Martínez-Navarro, 2010). The event takes its name from the spotted hyaena Crocuta crocuta, a typical African form whose oldest remains in Europe are from pre-Brunhes $(>0.78 \mathrm{Ma})$ levels TD3-TD7 at Gran Dolina, Spain, in association with the Asian wild pig Sus scrofa, the Asian red deer Cervus elaphus (Cuenca-Bescós et al., 2011), as well as the oldest proven hominin remains in
Europe (Carbonell et al., 1995) in level TD6 - the Aurora Stratum located just below the Brunhes-Matuyama boundary (Parés et al., 2013; see also below in Section 6.2.9). The two most iconic Galerian immigrants are, however, the megaherbivores Elephas antiquus and Mammuthus trogontherii. E. antiquus is regarded as an emigrant from Africa while M. trogontherii from Asia, and in a few hundred thousand years they replaced resident populations of M. meridionalis (e.g., Lister and Sher, 2001; Lister et al., 2005; Palombo and Ferretti, 2005; Martínez-Navarro, 2010).

The Leffe section of northern Italy, discussed in Section 3.1, yielded remains of $E$. antiquus from the (undated) loess-paleosol sequence located $\sim 45 \mathrm{~m}$ above the unconformity correlated to the 'R surface' that corresponds to MIS 22 (Muttoni et al., 2007) (Figs. 6 and 15). More germane to the discussion is the Vallparadís section in Spain (Martínez et al., 2010, 2014) that yielded remains of E. antiquus in unit EVT7 dated to between the top of the Jaramillo (0.99 Ma) and the base of the Brunhes (0.78 Ma) (MadurellMalapeira et al., 2010) (Fig. 14). Similarly, in the Guadix-Baza Basin of Spain, the Huéscar-1 site yielded remains of $E$. antiquus (Gibert et al., 2007, Table 1; references therein; but see Lister, 2004) from a level that was laterally traced onto the nearby Puerto Lobo magnetostratigraphic section (Gibert et al., 2007) to a level located $\sim 10 \mathrm{~m}$ below the Brunhes-Matuyama boundary and presumably above the Jaramillo, which was not found in the section (Fig. 14). The oldest remains of $M$. trogontherii in Europe are from the Kostolac section in Serbia (Fig. 1) (Lister et al., 2012) in levels currently dated to $0.8 \mathrm{Ma}$, shortly before the Brunhes-Matuyama boundary (Muttoni et al., 2015b; see also below) (Fig. 14). Remains of $M$. trogontherii came also from the site of Dorn-Dürkheim 3 in Germany from levels pre-dating the Brunhes-Matuyama boundary (Franzen et al., 2000) (Fig. 14).

These findings, depicting a relatively rapid scenario of faunal turnover outlined already by Azzaroli in 1983, are consistent with the Galerian migration hypothesis and in particular with the opening for the first time in the Pleistocene of an ecologically sustainable terrestrial conduit with open grasslands and reduced woody cover that large mammals such as Asian and African elephantidae could expand into (Fig. 13B and C). According to dental microwear analyses on proboscidean teeth (Rivals et al., 2012), the European resident $M$. meridionalis seems to have been more adapted to browsing, whereas immigrants $M$. trogontherii and $E$. antiquus were mixed browsers-grazers, and therefore more adapted to open grassland-reduced woody cover ecosystems that developed during the EPT since MIS 22 and the immediately succeeding MIS 22/MIS 21 transition. This dietary flexibility could have given $M$. trogontherii and $E$. antiquus an adaptive advantage relative to more forest-dependent $M$. meridionalis. In this view, the lack of viable conduits and exploitable ecosystems before the EPT forestalled African and Asian megaherbivores from expanding into Europe.

It is not clear what level early hominins occupied in the food pyramid, whether they were active hunters or scavengers (e.g., Domínguez-Rodrigo, 2002), but their dependence on animal proteins, and particularly animal fat from large herbivores, seems well established (e.g., Ben-Dor et al., 2011; Bolus, 2015). The late Early Pleistocene record of sites with evidence of butchery of large mammals, albeit still scanty (Gaudzinski et al., 2005; Mosquera et al., 2016; Pawłowska, 2017), seems to support this inference: Lower Paleolithic artifacts have been found in association with

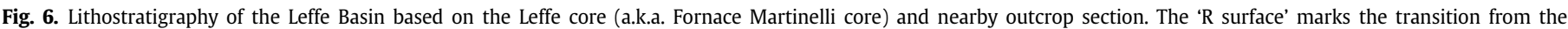

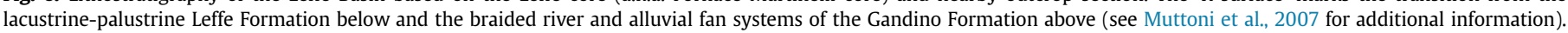

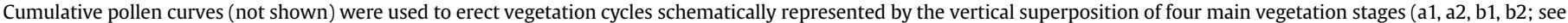

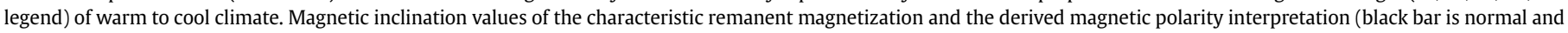
white is reverse polarity) are shown at right. 


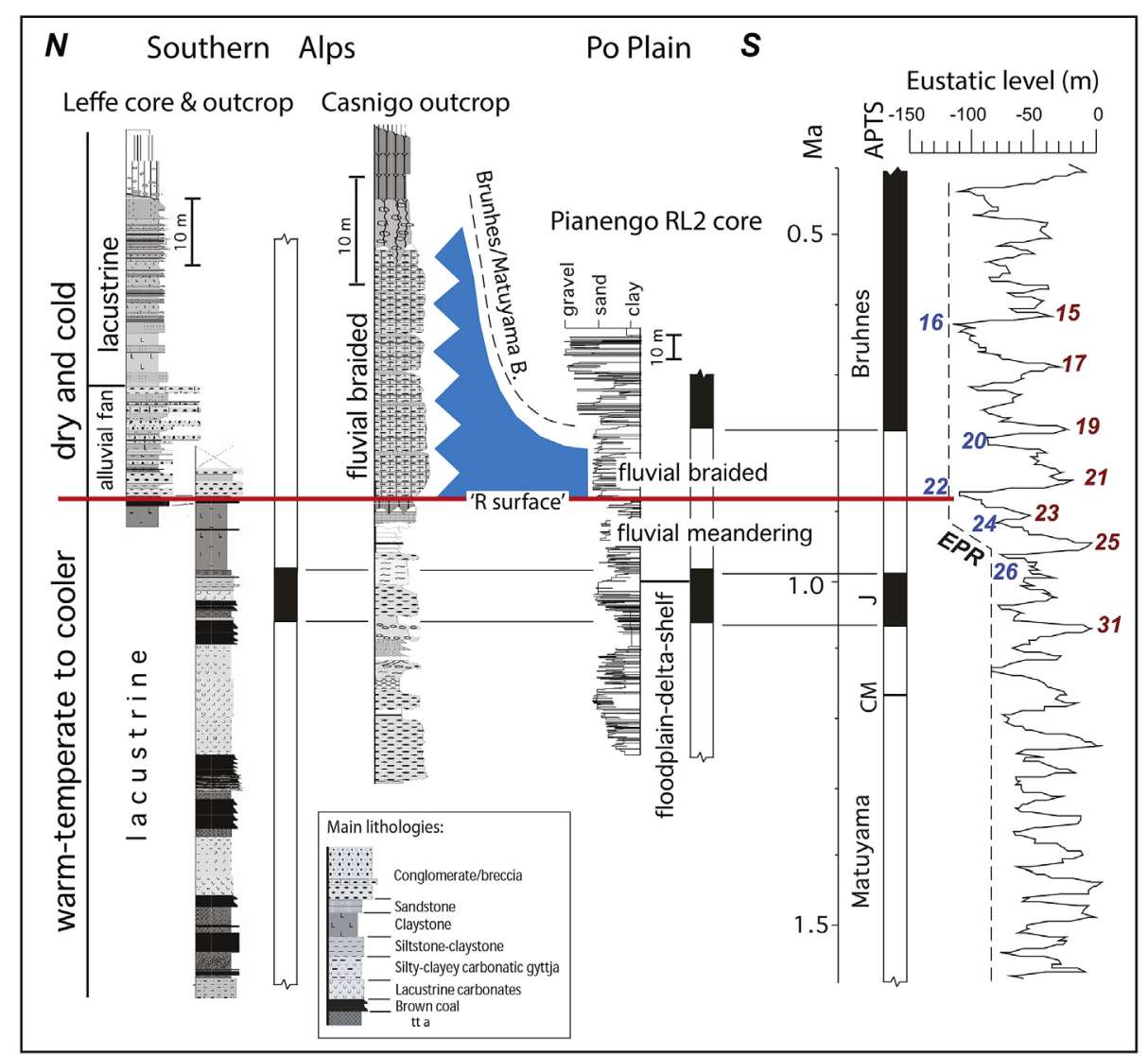

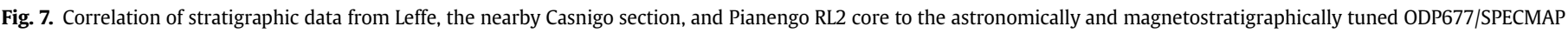

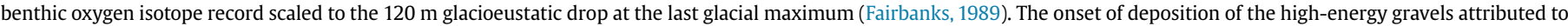

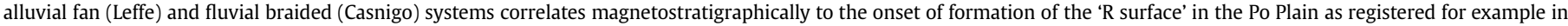

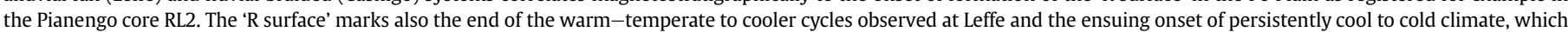

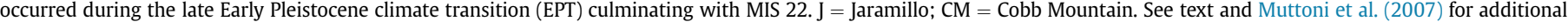
information.

mammal bones with cut marks interpreted as due to butchering at various European sites like Gran Dolina, Sima del Elefante, Barranco León, Barranc de la Boella, and Happisburgh (Mosquera et al., 2016; $<$ link id=bib_Pawlowska_2017>Pawlowska, 2017</link >). Our Galerian migration hypothesis does not imply, of course, that early hominins entered Europe hunting or scavenging only African and Asian Galerian mammals. The cultural innovations that accompanied the evolution of these early hominins (e.g, Bolus, 2015) allowed them to adapt to both the expanding Galerian and contracting Villafranchian foodwebs, as again suggested by the (scanty) archeostratigraphic record (Mosquera et al., 2016; <link id=bib_Pawlowska_2017 >Pawlowska, 2017</link $>$ ). Besides, if the conduit to Europe became open to large Galerian herbivores like elephantidae then it should not be surprising that the well-trod paths were also used by hominins whatever their dietary requirements might have been.

\section{Alternative migration routes}

Early African hominins are likely to have migrated from the northern fringes of the East African Rift, e.g., the Danakil depression of Eritrea (Albianelli and Napoleone, 2004) (Fig. 1), through the Nile Valley (e.g., Vermeersch, 2006) and into North Africa. It has been variably discussed (e.g., Straus, 2001) whether or not migrations could have occurred from North Africa directly into Europe. At the Aïn Hanech site in Algeria (Fig. 1), levels containing Oldowan lithic tools were attributed an age of $\sim 1.7$ Ma based on magnetostratigraphy in conjunction with the chronology derived from the morphology of a tooth attributed to the suid Kolpochoerus heseloni and the recovery of a tooth fragment attributed to the proboscidean Anancus (Parés et al., 2014 and references therein). Alternative ages for the tool levels on the order of $~ 1.5-1.2$ Ma were proposed based on mammal biostratigraphy alone (Geraads, 2010; references therein; see also discussion in Muttoni et al., 2014). At the Thomas Quarry site in Atlantic Morocco (Fig. 1), Acheulean lithic tools and hominin remains have been dated with biostratigraphic, ESR, and OSL methods, but the obtained results appear as yet conflicting, spanning from the Early to the Middle Pleistocene (Raynal et al., 2010).

In any case, a hominin presence in North Africa during the Early Pleistocene offers the tempting solution of a Gibraltar Strait crossing into Spain or a Sicily Channel crossing into Italy (Fig. 1), although these are considered unlikely routes by a number of authors (e.g., Villa, 2001; Straus, 2001; Derricourt, 2005). The Sicily Channel, now $\sim 145 \mathrm{~km}$ wide, was largely submerged (albeit possibly reduced in width) even during maximum Pleistocene sea level low-stands based on evidence of mammal endemism in Sicily (e.g., Villa, 2001). A Gibraltar Strait crossing has been recently revived by findings at Cueva Victoria in southeastern Spain (Fig. 1) that yielded remains of various African species including Theropithecus oswaldi. Magnetostratigraphic analyses constrain the age of the fossiliferous breccia between the top of the Jaramillo (0.99 


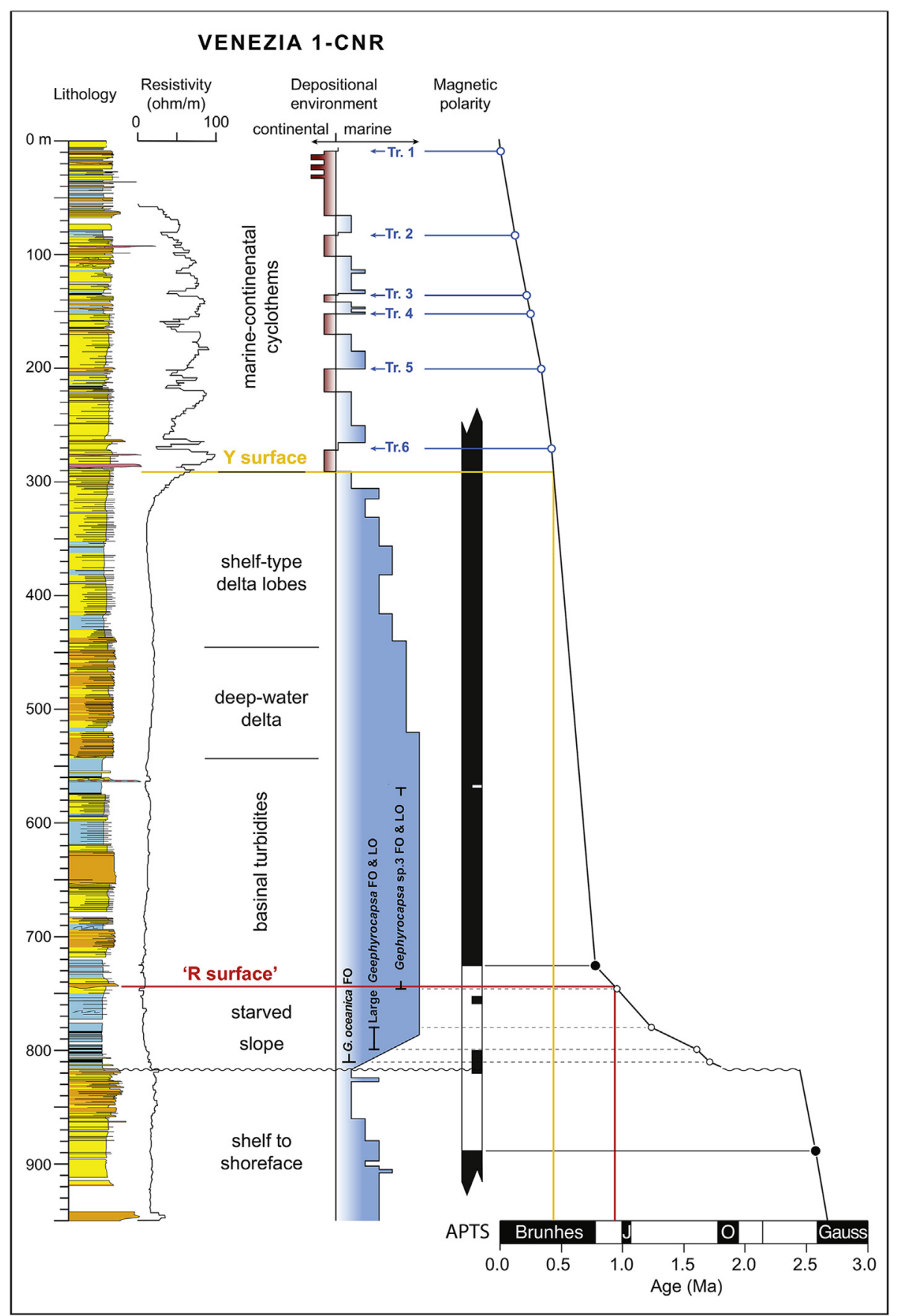

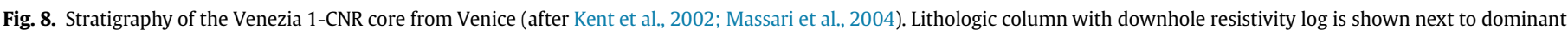

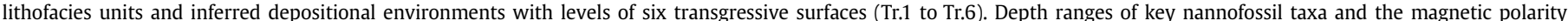

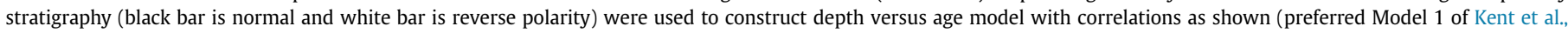

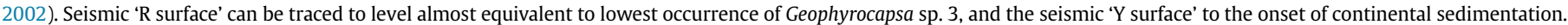

$\mathrm{Ma}$ ) and the Brunhes-Matuyama boundary (0.78 Ma) during the EPT (Gibert et al., 2016). These authors concluded that the presence of T. oswaldi and Homo in North Africa at similar times and the absence of T. oswaldi in other localities in Europe suggest dispersal from Africa to Iberia through the Strait of Gibraltar during MIS 22 when sea level was $\sim 100 \mathrm{~m}$ below its present position and the width of the Gibraltar Strait was reduced. We notice, however, that the Gibraltar Strait area, located at the margin between the African and Eurasian plates, has been experiencing tectonic uplift of $\sim 0.2$ $\mathrm{mm} / \mathrm{yr}$ (Zazo et al., 1999) as evidenced by a sequence of raised
Pleistocene shorelines as high as $210 \mathrm{~m}$ above present sea level (e.g., Rodríguez-Vidal et al., 2004; El Kadiri et al., 2010). If this uplift rate is extrapolated back to $0.9 \mathrm{Ma}$ and a maximum glacioustatic oscillation of typically $\sim 120 \mathrm{~m}$ is assumed (Fairbanks, 1989), the central channel would have had during MIS 22 a depth $(\sim 300 \mathrm{~m})$ and total minimum breadth $(\sim 15 \mathrm{~km})$ not dissimilar from today's geography. In that respect, the Gibraltar Strait probably was - and continues to be - a significant barrier for mammal migrations, at least for establishing a stable and repeated connection with Africa for continental-scale peopling of Europe accompanied by a wide 


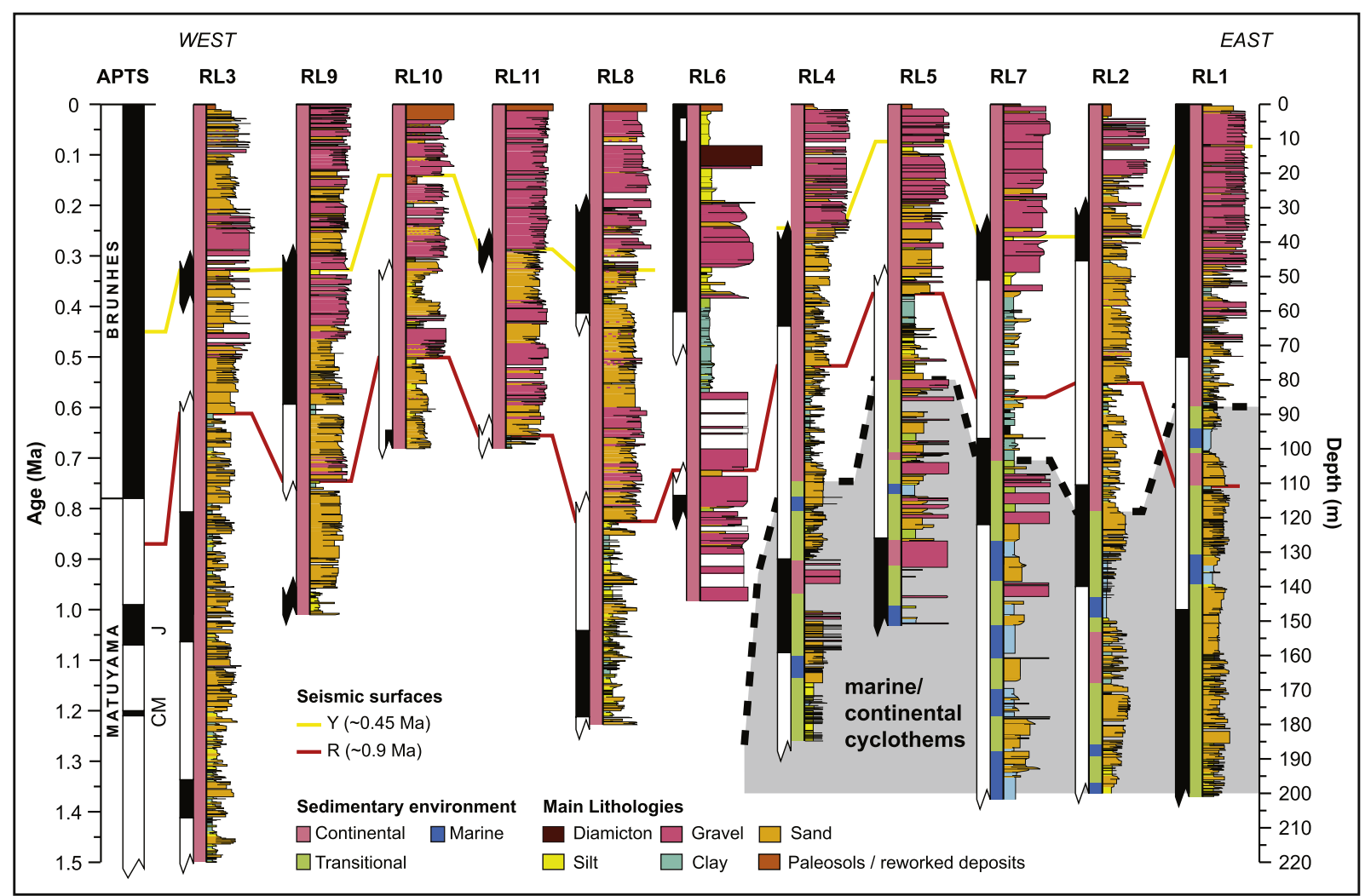

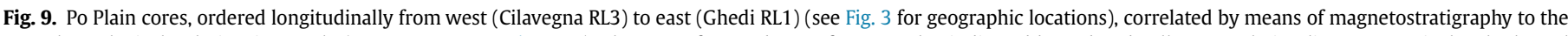

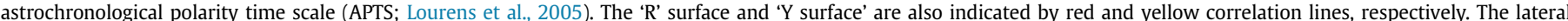

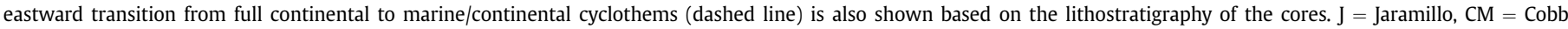
Mountain. See text and Scardia et al. (2012) for additional information.

variety of megaherbivores. This is incidentally true also for the much later anatomically modern humans, as Straus (2001) pointed out: "Among the "superior characteristics" of African-originating Homo sapiens there was apparently not an ability to cross the Strait of Gibraltar or a capacity for displacing the South Iberian Neanderthals from either the south or north until less than 30,000 years ago' and again 'it is only in the terminal Paleolithic that [...] a credible case can be made for trans-Gibraltar human contacts'. This statement still holds today according to recent findings: although Homo sapiens was already in Morocco at 300 ka (Hublin et al., 2017; Richter et al., 2017), its earliest occurrence in Europe is only recorded since 40 ka (Benazzi et al., 2011; Higham et al., 2011), more than 200 ka later, supporting the view that the Strait of Gibraltar acted more as a migration barrier rather than a migration route.

As stressed elsewhere (Muttoni et al., 2014), there is a fundamental difference between a Po-Danube terrestrial conduit route and a Gibraltar Strait (or Sicily Channel) crossing route: through a Po-Danube terrestrial conduit, mammals and hominins reached Europe because they expanded into new, stable, exploitable and sustainable ecosystems first created during the EPT. On the contrary, a Gibraltar Strait or Sicily Channel crossing would imply either a random event or the dubious ability of early hominins (not to mention the elephants) to overcome a significant water barrier, which would be expected to act as a severe filter rather than a sustainable passage.

In conclusion, paraphrasing Straus (2001): '[...] it remains to be demonstrated if some of the oldest hominid occupations in Europe proper (i.e. outside the southern Caucasus) - namely those of Spainwere the result of migrations via the shortest, most direct route - the Strait of Gibraltar - or via the longest, most circuitous one - i.e.,
Levant-Anatolia-Dardanelles-Balkans-Northern Italy-Southeastern France. If the latter, then many sites remain to be found in those regions for the period between ca. 1.8 and $1 \mathrm{Ma!}$ !. This prediction offers a way to test our Galerian migration hypothesis.

\section{The European earliest hominin chronology}

The Galerian migration hypothesis holds on the tight temporal link between the oldest (and best-dated) hominin sites in Europe and the environmental-faunal turnover in the EPT centered on MIS 22 and the MIS 22/21 transition at $\sim 0.9-0.85 \mathrm{Ma}$. Any hominin site in Europe with a robust age determination older than approximately 1 Ma would therefore falsify the hypothesis or at least put it in jeopardy. We review and critique published accounts of the oldest hominin sites and/or sites with Galerian mammals of African-Asian origin in Europe with this test in mind, and include what we regard as the best-dated sites available (Fig. 15).

\subsection{Gates of Europe}

Hominins proceeded to Europe from staging areas at the Gates of Europe, where they were already present well before $0.9 \mathrm{Ma}$, for example, at the celebrated site of Dmanisi in Georgia (Fig. 1), dated to $1.8 \mathrm{Ma}$, as well as in Turkey and the Levant (Fig. 15). In southwestern Turkey, the presumed $H$. erectus level from Kocabas (Fig. 1) has been recently constrained with magnetostratigraphy from 1.3 Ma to 1.1 Ma (Lebatard et al., 2014). However, we stress that the stratigraphic position of the hominin skull is uncertain because it was not found directly within the magnetostratigraphic sequence but within an isolated travertine block. We therefore provisionally 


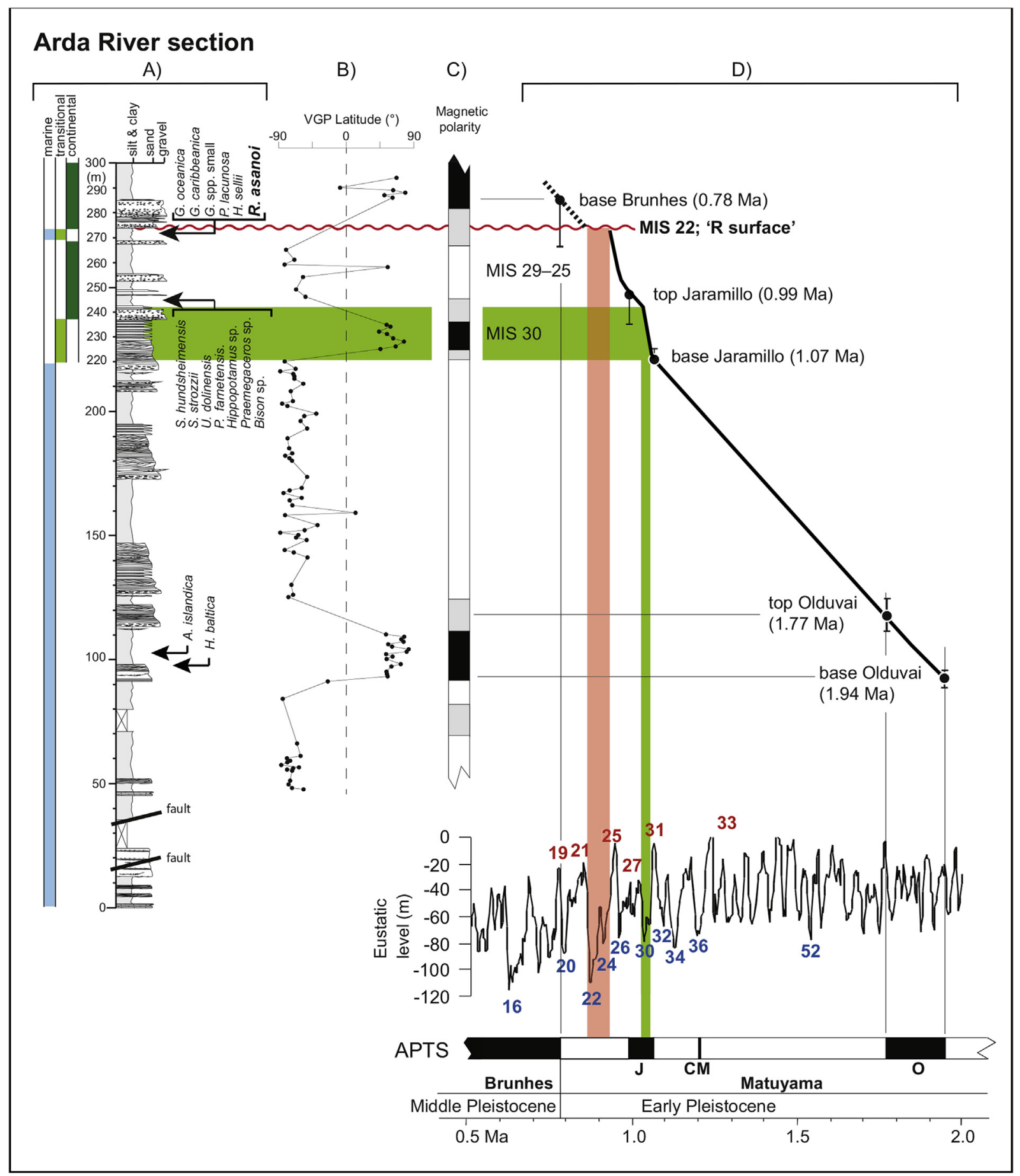

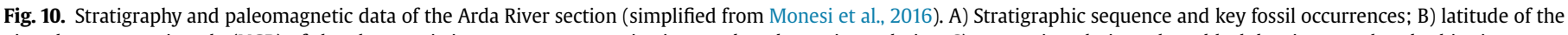

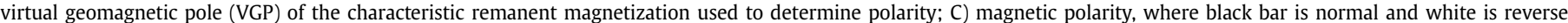

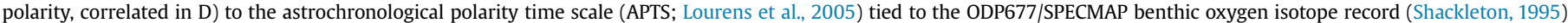
scaled to the glacio-eustatic drop at the last glacial maximum (Fairbanks, 1989). $\mathrm{J}=$ Jaramillo subchron, CM $=$ Cobb Mountain subchron, O $=$ Olduvai subchron.

exclude Kocabas from the inventory of well-dated sites of Fig. 15. In south-central Turkey, the site of Dursunlu (Fig. 1) yielded levels with Oldowan lithic tools correlated to a normal-reverse-normalreverse polarity sequence retrieved from a drill core (Güleç et al., 1999, 2009) but no information on the procedures adopted to obtain the polarity stratigraphy was provided, and hence this site is also discarded from further consideration. In western Turkey, levels with lithic tools from the Gediz River terraces (Fig. 1) were constrained using ${ }^{40} \mathrm{Ar} /{ }^{39} \mathrm{Ar}$ radiochronology and paleomagnetic data to a time period spanning from $\sim 1.24$ Ma to $\sim 1.17 \mathrm{Ma}$ (Maddy et al., 2015) (Fig. 15).

The Levant yielded the sites of 'Ubeidiya (Fig. 1), with tools from levels of exclusive reverse polarity (Opdyke et al., 1983) and with ESR age estimates on the order of 1.3-1.2 Ma (Rink et al., 2007) (Fig. 15), as well as Gesher Benot Ya'aqov and Evron (Fig. 1), with Acheulean lithic tools from levels just below the 


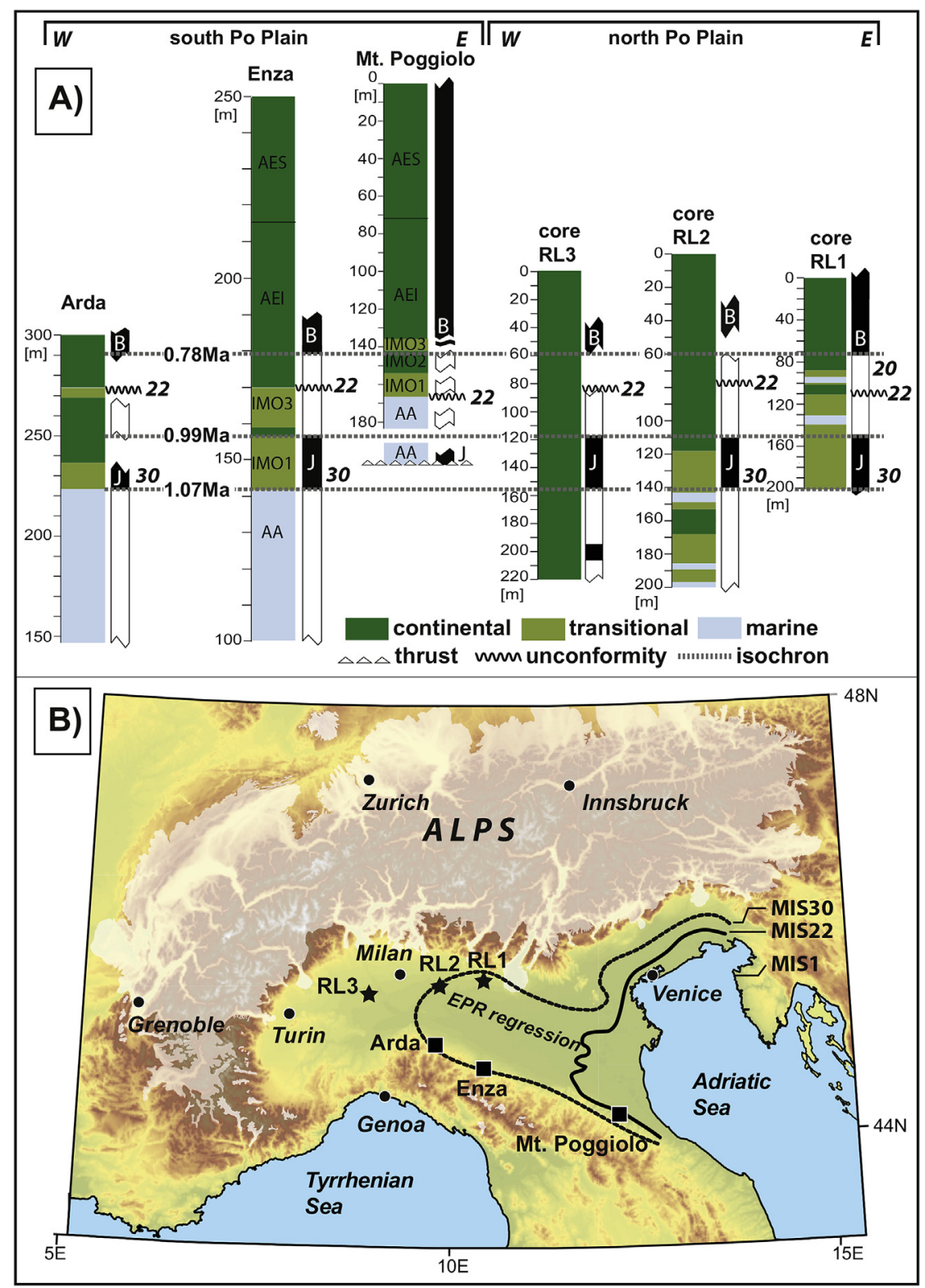

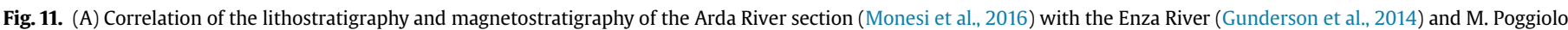

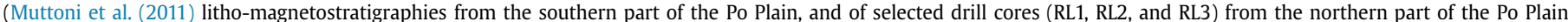

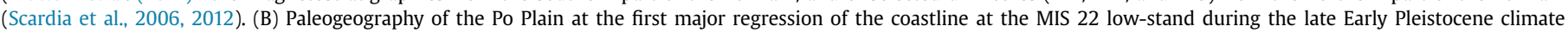

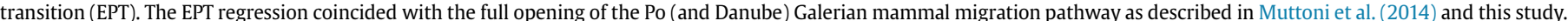

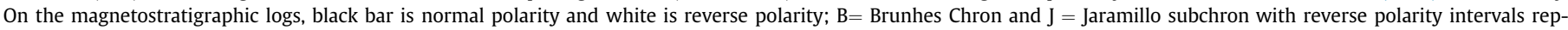

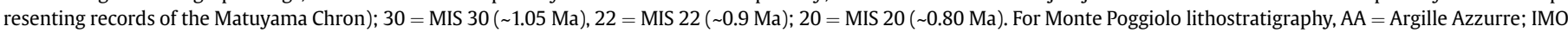

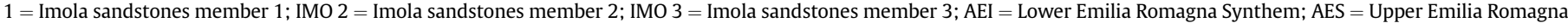
Synthem. See text and Monesi et al. (2016) for additional information.

Brunhes-Matuyama boundary (Goren-Inbar et al., 2000; Ron et al., 2003) (Fig. 15). Additional sites in Israel are Erk-el-Ahmar (Fig. 1), where however levels with Oldowan lithic tools are not confidently correlated to the magnetostratigraphic profiles showing a reversenormal-reverse polarity sequence (Braun et al., 1991; Ron and Levi, 2001), and Bizat Ruhama, where Oldowan lithic tools were found in a reverse polarity interval attributed to the late Matuyama (postJaramillo?) on the basis of integrated paleomagnetic and radiothermoluminescence (RTL) data (Laukhin et al., 2001).

The chronology of these putative staging areas suggests that hominins were well established at the Gates of Europe since at least 1.8 Ma with different available technologies, i.e. Oldowan and
Acheulean, but entered Europe for the first time no earlier than $\sim 1.4$ Ma and most probably, as we argue, during the EPT centered at 0.9 Ma.

\subsection{Europe}

\subsubsection{Kozarnika, Bulgaria}

Recent evidence in support of the Galerian migration hypothesis comes from the tool-bearing Kozarnika cave sediments in Bulgaria (Sirakov et al., 2010) (Fig. 1). The chronostratigraphy of the section (Fig. 16), based on small and large mammal associations, is controversial especially of the inferior layers that bear Lower 


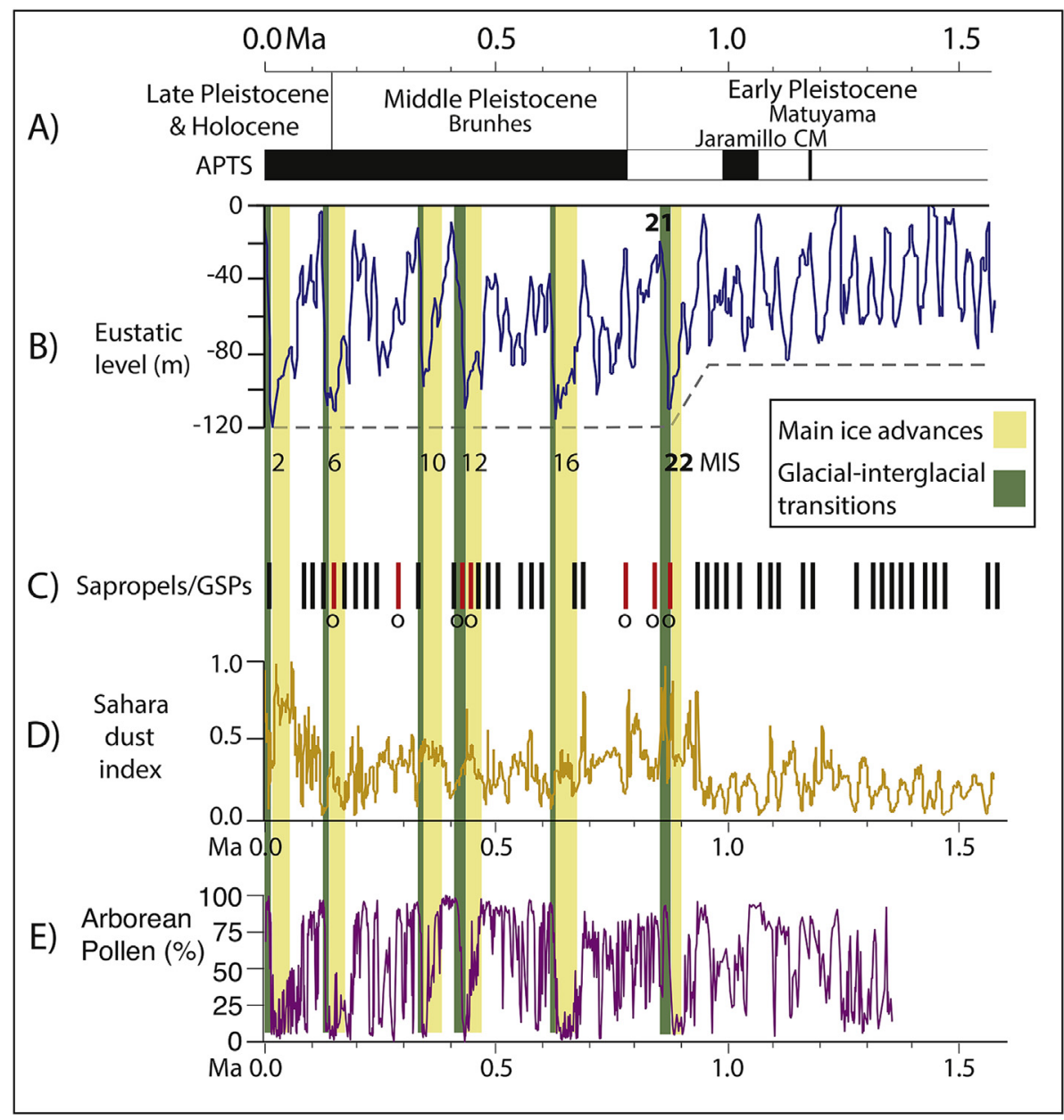

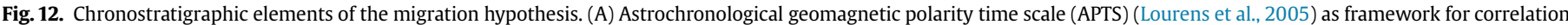

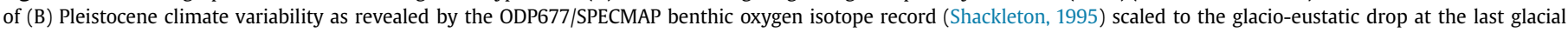

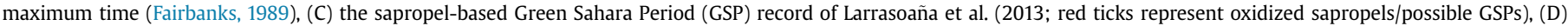

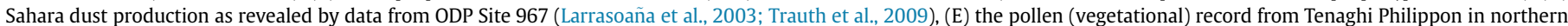

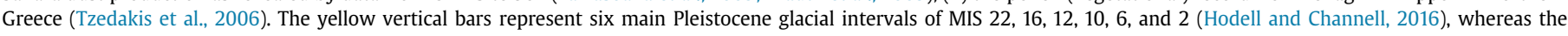

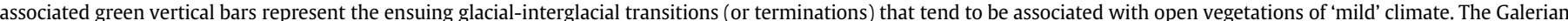

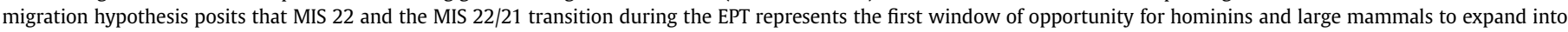
Europe across the conjunct Po-Danube conduit that became fully emergent and terrestrial during MIS 22 at $\sim 0.9 \mathrm{Ma}$.

Paleolithic tools. Small mammals provide a record that according to standard bio-magnetochronology should span in relative continuity virtually the entire Brunhes Chron, across the Brunhes-Matuyama boundary and back into the Jaramillo normal polarity subchron (Popov and Marinska, 2007). In contrast, large mammals seem to indicate that the lower layers (11b-13) should belong to Mammal Neogene/Quaternary (MNQ) zones 19 to 17 (Sirakov et al., 2010; but see Kahlke et al., 2011), which, according to a recent radiochronologic $\left({ }^{40} \mathrm{Ar} /{ }^{39} \mathrm{Ar}\right)$ reassessment of classic mammalian localities from France, should correspond to a time interval broadly comprised between $\sim 1.2$ and $\sim 2.6$ Ma (Nomade et al., 2014). In terms of expected magnetochronology, this should be from the middle Matuyama reverse chron, straddle the Olduvai normal geomagnetic polarity subchron $(1.78-1.95 \mathrm{Ma})$ and extend back to the Matuyama-Gauss boundary (2.6 Ma).

A magnetostratigraphic study of the cave infill (Fig. 16) (Muttoni et al., 2017) reveals the presence of a relatively thick and well defined normal magnetic polarity interval in the upper part of the section, interpreted as a record of the Brunhes Chron, underlain by sediments with reverse polarity magnetizations. The Brunhes-Matuyama boundary is placed in the upper part of Layer 13
Lower. The lowermost levels with Lower Paleolithic tools (Layers $13 a-c)$ fall in the early Brunhes close to the Brunhes-Matuyama boundary at a nominal maximum age of $\sim 0.75 \mathrm{Ma}$ (Muttoni et al., 2017) (Fig. 16). These results support the small mammal age option and are not in contradiction with the timing of the Galerian migration hypothesis (Fig. 15).

\subsubsection{Kostolac, Serbia}

A regional horizon marks the onset of enhanced glacial activity during the EPT, onto which thick loess deposition occurred during main Pleistocene glacial advances since MIS 22 across vast stretches of the Pannonian basin. This stratigraphic level represents a prime target for surveys in search of sites with Galerian mammal immigrants from Asia and Africa, possibly including early hominins. For example, in the Drmno open-pit coal mine near Kostolac in Serbia (Fig. 1), a nearly complete skeleton of $M$. trogontherii (nicknamed Vika) was discovered in a fluvial deposit overlain by a loesspaleosol sequence (Lister et al., 2012; Dimitrijević et al., 2015) (Fig. 17).

Magnetostratigraphic data from the Kostolac sedimentary succession yielded evidence for an upper normal-lower reverse 
A) Pre-MIS22 low-stands (> 0.9 Ma): Danube-Po Gateway closed

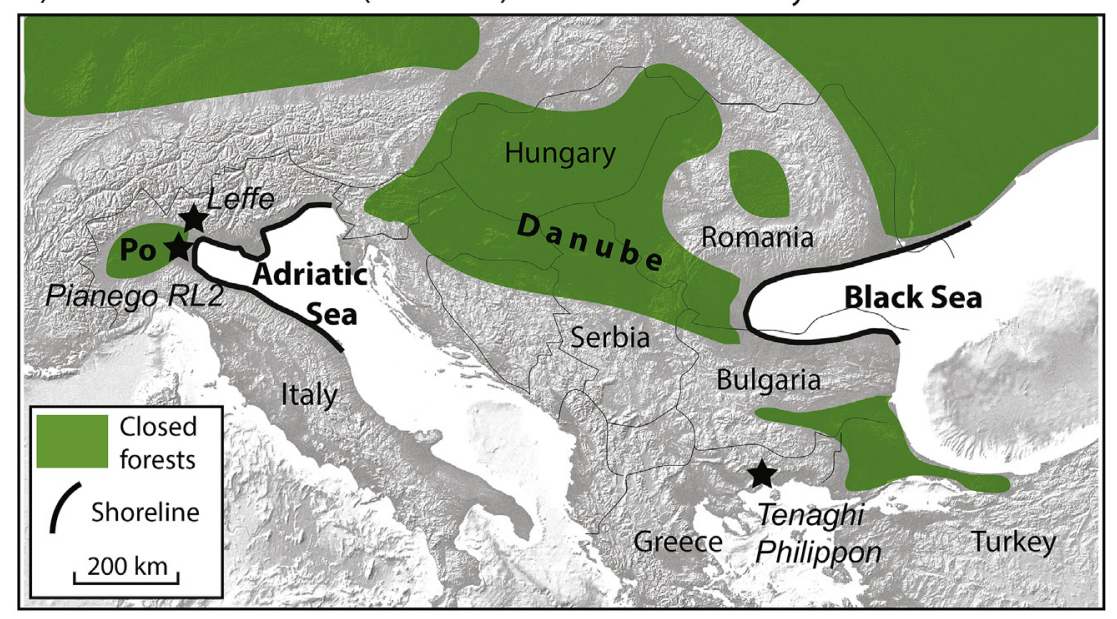

B) MIS22 low-stand ( 0.9 Ma): Danube-Po Gateway open

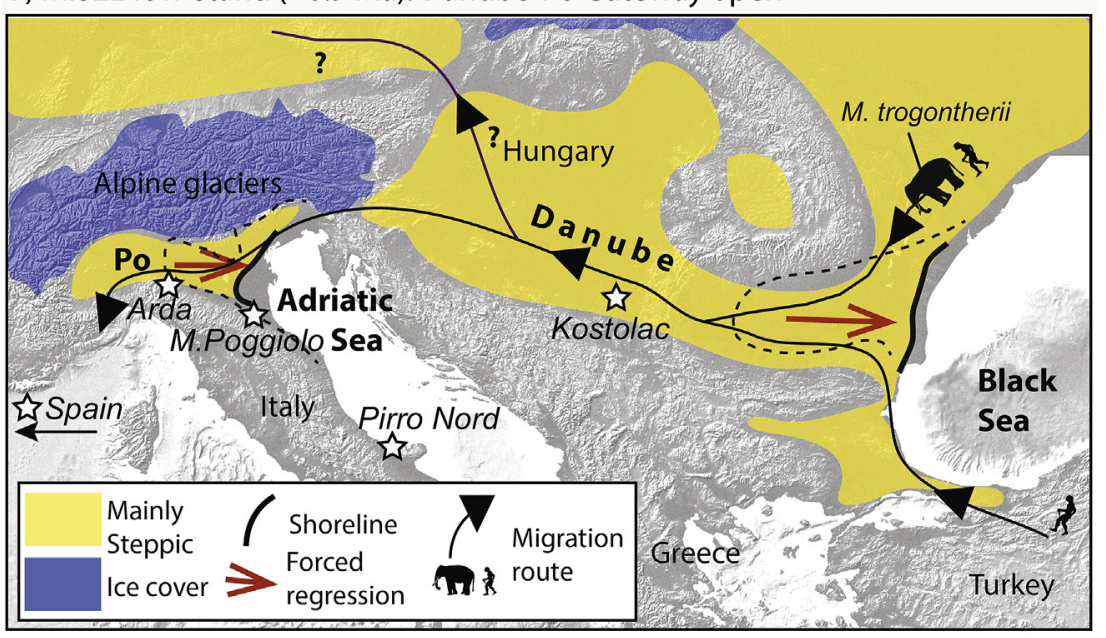

C) MIS22/21 transition ( 0.85 Ma): Danube-Po Gateway open

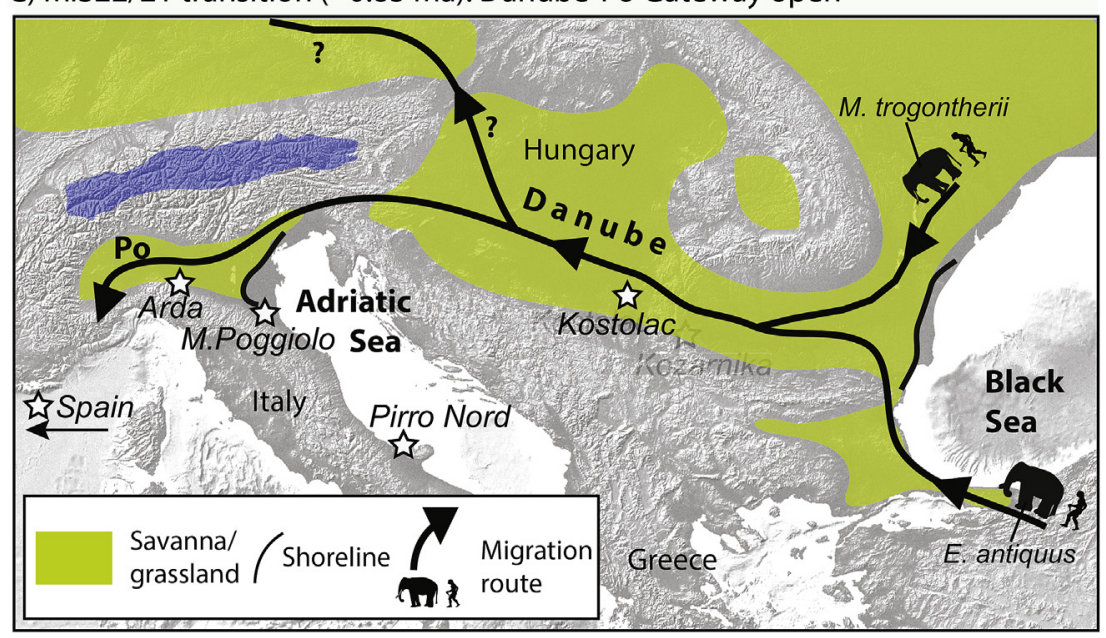

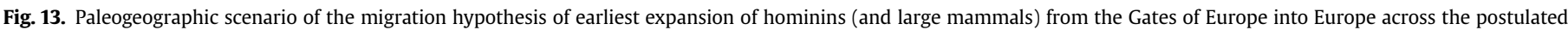

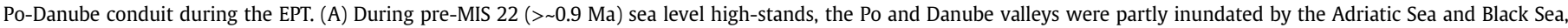

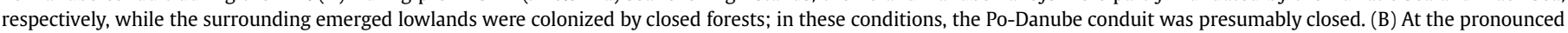

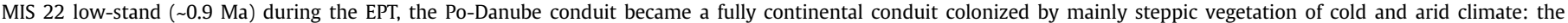

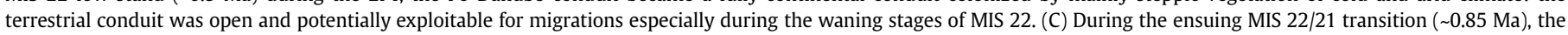
terrestrial conduit was colonized by grassland vegetation and/or open forests, and was fully exploitable for hominin and Galerian mammal migrations. 


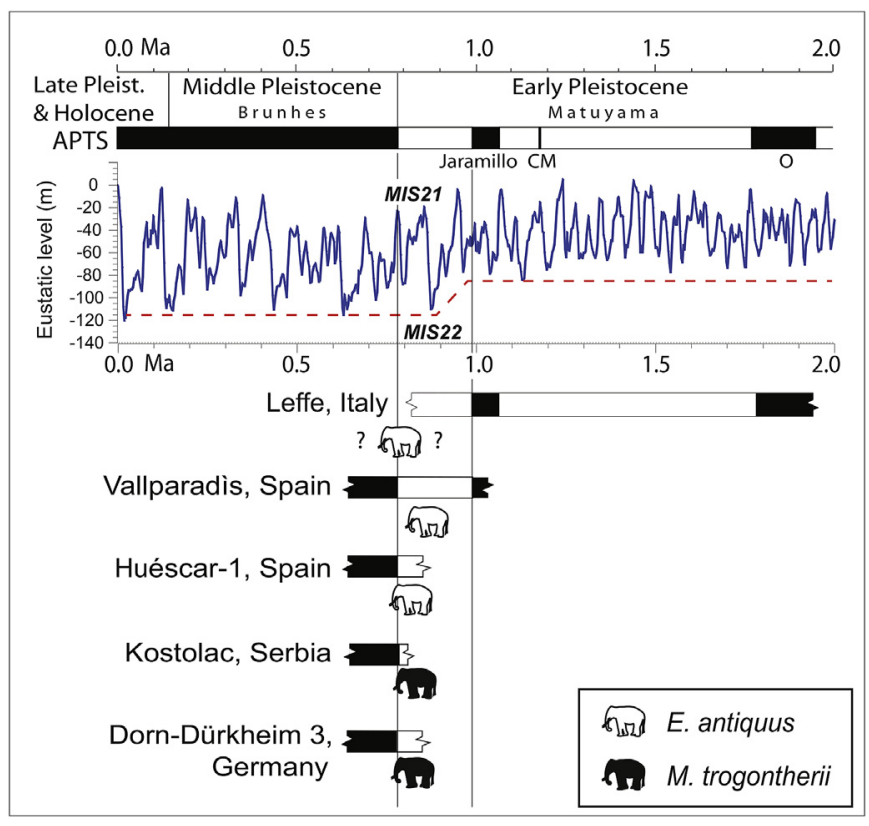

Fig. 14. Chronologies based essentially on magnetostratigraphy of mammal sites registering the first occurrences in Europe of Asian $M$. trogontherii and African E. antiquus, two of the far-traveled Galerian herbivores that first entered Europe during the EPT centered on MIS 22 and the ensuing MIS22/21 transition. The astrochronological polarity time scale (APTS) is from Lourens et al. (2005) where black is normal geomagnetic polarity and white is reverse polarity. For site location, see Fig. 1, and for references, see text.

polarity sequence interpreted as a record across the BrunhesMatuyama boundary (Muttoni et al., 2015b). The Vika layer was traced to just below the Brunhes-Matuyama boundary at a nominal age of $0.8 \mathrm{Ma}$ (Fig. 17), thus providing a hard piece of evidence in favor of the Galerian migration hypothesis (Muttoni et al., 2015b). Most notably, Kostolac lies, like Kozarnika (see above), exactly on the postulated Danube terrestrial conduit that the Asian immigrant $M$. trogontherii was exploiting for the first time around the time of MIS 22 (Fig. 13). As stressed in Section 4.2, $M$. trogontherii seems to have immigrated at broadly the same time (within a climatic cycle of typically $100 \mathrm{kyr}$ ) as E. antiquus came from Africa (Fig. 14), again in substantial agreement with the Galerian migration hypothesis.

\subsubsection{Monte Poggiolo, Italy}

A further testing attempt was performed at the site of Cà Belvedere near Monte Poggiolo in northern Italy (Fig. 1). This site yielded an industry of in situ-knapped Oldowan pebbles and flakes in levels where previous paleomagnetic analyses indicated the presence of reverse polarity magnetizations attributed to the Matuyama Chron (Peretto et al., 1998; Peretto, 2006; Gagnepain et al., 1998). Electron Spin Resonance (ESR) dates on quartz grains obtained directly from the archeological levels (Peretto et al., 1998; Gagnepain et al., 1998) yielded, after recalculation (Falguères, 2003), a mean age of $1.06 \pm 0.32 \mathrm{Ma}$ (at $2 \sigma$ ), which made it unclear whether the timing of hominin occupation actually conflicted with the Galerian migration hypothesis. To resolve this uncertainty, new magneto-biostratigraphic data were obtained from 5 sections documenting the Monte Poggiolo sedimentary sequence augmented by data from a deep core previously drilled in the adjacent Po Plain (Muttoni et al., 2011 and references therein) (Fig. 18).

The derived age model of sedimentation evidenced the presence of a major unconformity separating Pliocene shallow marine clays

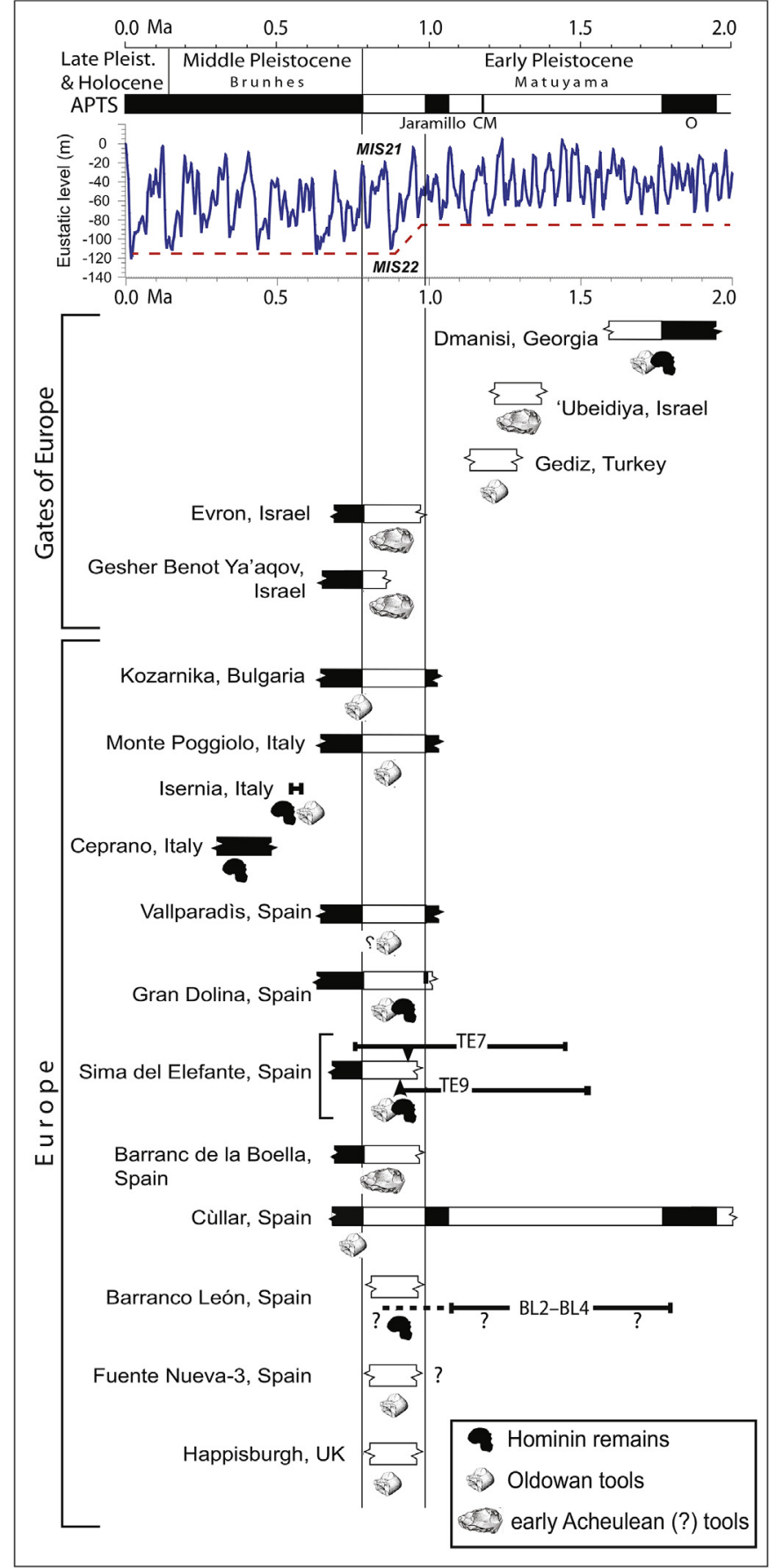

Fig. 15. Our preferred interpretation of evidence for the earliest human occupation of Europe and at the Gates of Europe in the Levant with respect to the astrochronological polarity time scale (APTS; Lourens et al., 2005). Polarity columns show black bars for normal geomagnetic polarity and white for reverse polarity. Oldest key hominin sites with reliable magnetostratigraphies occur within the reverse polarity interval between the Jaramillo and the Brunhes (0.99-0.78 Ma) that contain the EPT and MIS 22. Additional sites marked with a question mark have in our opinion open chronologies that at present do not exclude them from pertaining to the same EPT age window as the best-dated sites. Oldowan (Mode I) and Acheulean (Mode II) represent lithic technologies that have dubious chronostratigraphic significance since they appear in the stratigraphic record at almost the same time in Africa (Lepre et al., 2011). See text for references and discussion. 


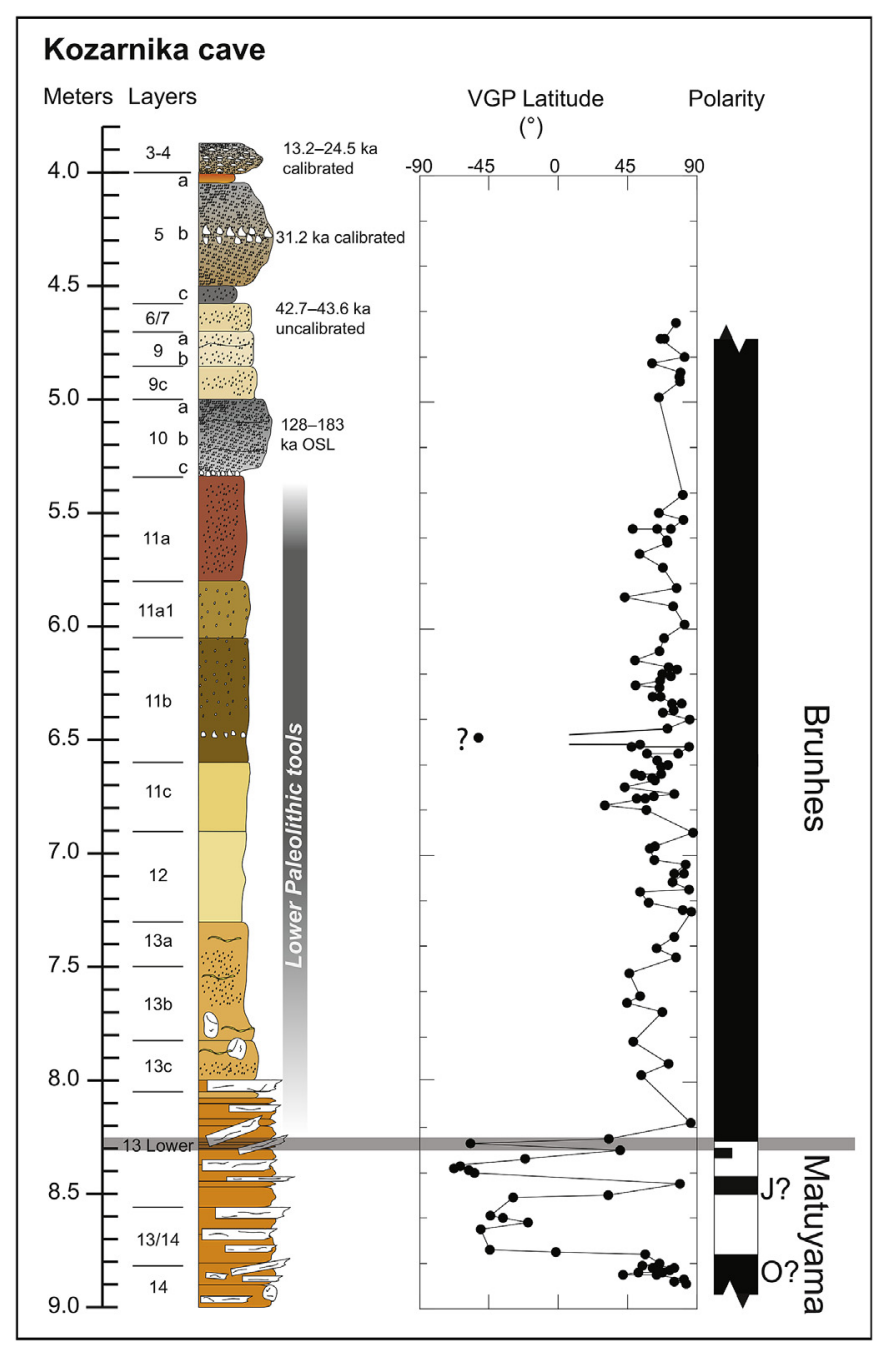

Fig. 16. Key paleomagnetic data of the Kozarnika cave sediments (from Muttoni et al., 2017). Virtual geomagnetic pole (VGP) latitudes are used to erect magnetic polarity where black is normal polarity and white is reverse polarity. The Brunhes-Matuyama boundary $(0.78 \mathrm{Ma})$ falls at $\sim 8.3 \mathrm{~m}$ within the upper part of Layer 13 Lower. The lowermost levels with Lower Paleolithic tools are in Layers 13a-c in the early Brunhes close to the Brunhes-Matuyama boundary. J? And $\mathrm{O}$ ? are speculative records of the Jaramillo and Olduvai subchrons, respectively; see Muttoni et al. (2017) for additional informations.

of the Argille Azzurre Auctorum below from littoral sands of the Imola 1 Member (IMO1) of the Imola Sands above. This unconformity was constrained using magnetostratigraphy and nannofossil biostratigraphy to a reverse polarity interval comprised between the top of the Jaramillo and the base of the Brunhes, and was correlated to the pronounced sea level fall (forced regression) culminating with the MIS 22 low-stand (Fig. 18). IMO1 with lithic tools was interpreted to have been deposited during MIS 21 ( 0.85 Ma) (Muttoni et al., 2011). This age closely associates human presence at Monte Poggiolo to the EPT and is in substantial conformance with the timing of the Galerian migration hypothesis (Fig. 15).

\subsubsection{Arda, Italy}

An attempt was recently made to trace the Galerian migration on the western (Po Plain) sector of the Po-Danube conduit at the Arda River section discussed in Section 3.2 for the timing of full continentalization of the Po Plain during MIS 22 at 0.9 Ma. Monesi et al. (2016) described a mammal bed present in the Arda section and approximately dated to the MIS 27-29 interval centered at $\sim 0.99 \mathrm{Ma}$ (top Jaramillo) (Fig. 10). The faunal assemblage comprises taxa such as Pseudodama and Sus strozzii attributed to the Villafranchian mammal age, co-existing with the large cervid Praemegaceros and the bear Ursus dolinensis $(=U$. rodei), which are commonly considered to pertain to the earliest part of the Galerian mammal age (Kalkhe, 2007; Gliozzi et al., 1997; Masini and Sala, 2007).

This mixed faunal assemblage was interpreted as registering the onset of the Galerian mammal replacement of Villafranchian taxa. For example, Ursus dolinensis may have emigrated from central Europe where it was found at Untermassfeld (Germany) in levels attributed to MIS 31 at the base of the Jaramillo ( 1.07 Ma) (Kahlke, 2006; Kahlke et al., 2011) whereas Sus strozzii was present in the Italian peninsula since the Early Pleistocene (pre-Jaramillo) Farneta faunal unit (Gliozzi et al., 1997; Masini and Sala, 2007). Monesi et al. (2016) reasoned that it was only when fully continental conditions were established in the entire Po Plain during (and periodically after) the MIS 22 regression (Fig. 11; see Section 3.2) that the Galerian faunal turnover could take place in its full extent with the first entrance in the Italian peninsula of immigrant mammals coming from the east along the Danube conduit such as E. antiquus and $M$. trogontherii, as well as hominins with them (none of them yet found at Arda).

\subsubsection{Ceprano, Italy}

Ceprano (Fig. 1) was a test focused on the age of the alleged oldest hominin fossil in Italy: the incomplete hominin cranium discovered in 1994 along a roadcut near Ceprano, southeast of Rome. The fossil cranium was ascribed over the years to different hominin species from $H$. cepranensis (Mallegni et al., 2003) to an ancestral morphotype of the $H$. heidelbergensis/rhodesiensis hypodigm (Bruner and Manzi, 2007). Using stratigraphic correlations from discontinuous continental sections, the Ceprano cranium was considered by several authors to be close to the Brunhes-Matuyama boundary (Ascenzi et al., 1996, 2000; Ascenzi and Segre, 1997; Manzi, 2004), even though no paleomagnetic data were provided in support of this interpretation.

To address this chronologic uncertainty, two drill cores were taken at the discovery site and studied for magnetostratigraphy (Muttoni et al., 2009). Quite surprisingly, the Brunhes-Matuyama boundary was not encountered in the Ceprano cores down to at least $45 \mathrm{~m}$ below the level that yielded the hominin cranium (Muttoni et al., 2009) (Fig. 19), indicating that the age of the discovery level could not be very close to the Brunhes-Matuyama boundary as previously suggested (e.g., Manzi, 2004). Instead, an age model of sedimentation based on the lithostratigraphy and magnetostratigraphy of the cores in conjunction with $\mathrm{K}-\mathrm{Ar}$ dates from the literature comprised between $0.354 \mathrm{Ma}$ and $0.583 \mathrm{Ma}$ indicated a likely age $0.45(+0.05,-0.10)$ Ma for the level that yielded the hominin cranium (Muttoni et al., 2009). ${ }^{40} \mathrm{Ar} /{ }^{39} \mathrm{Ar}$ dating was subsequently applied on K-feldspars from sediments that hosted the cranium and yielded an age of $0.353 \pm 0.008 \mathrm{Ma}$ (at $2 \sigma$ ) (Nomade et al., 2011) (Fig. 19). Therefore, the hominin level at Ceprano turns out to be well within the Brunhes Chron, much younger than the originally presumed Brunhes-Matuyama boundary (Fig. 15).

\subsubsection{Pirro Nord, Italy}

The Pirro Nord tool-bearing site from southern Italy (Fig. 1) has been attributed an age of 1.6-1.3 Ma (e.g., Arzarello et al., 2012; Pavia et al., 2012) in open conflict with the timing of the Galerian migration hypothesis. The Pirro karst infill of fluvial sands and conglomerates yielded reverse polarity magnetizations (Pavia et al., 2012 ) indicating a pre-0.78 Ma age. The proposed age of $1.6-1.3 \mathrm{Ma}$ 


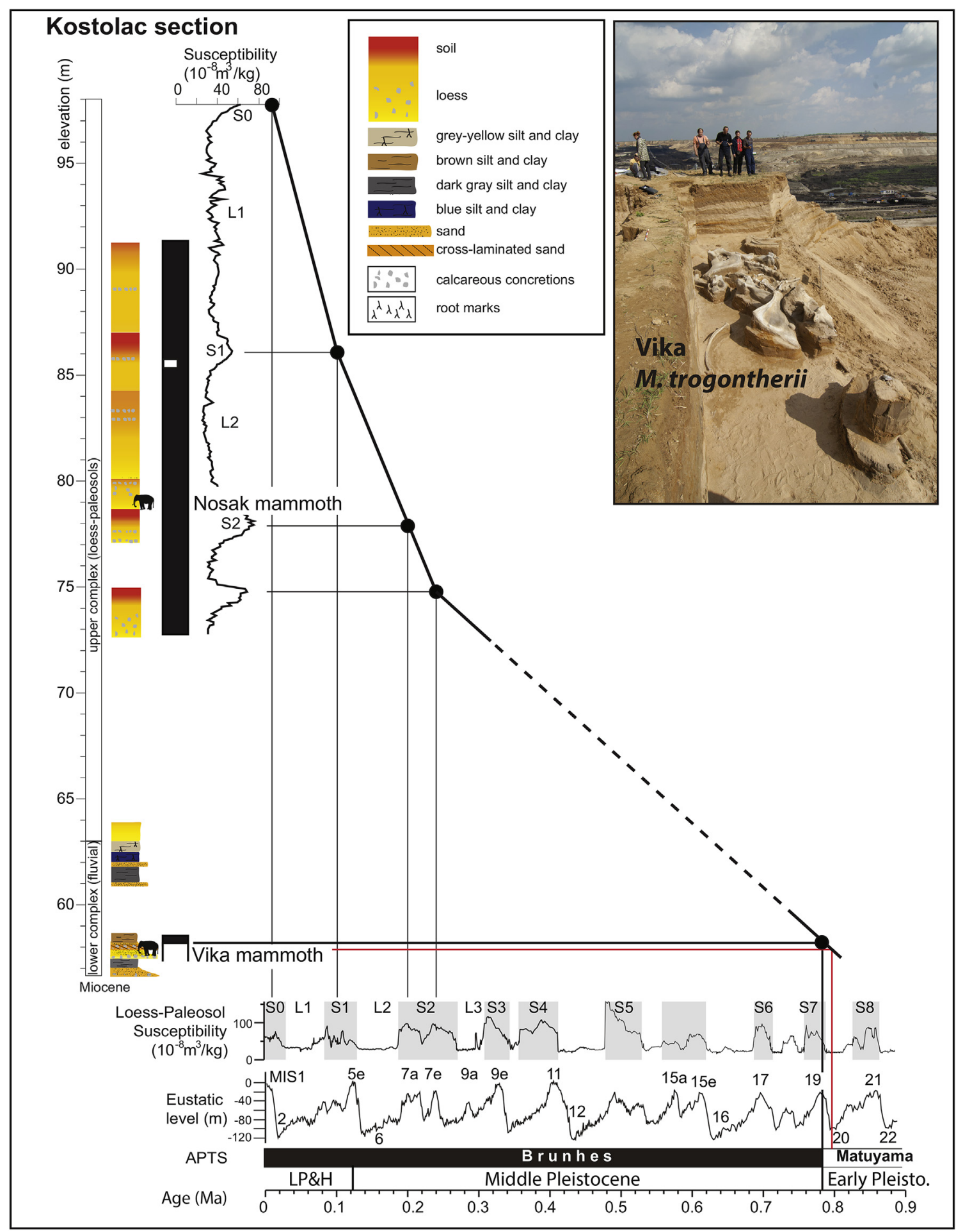

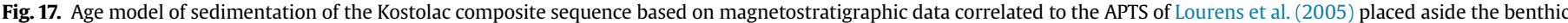

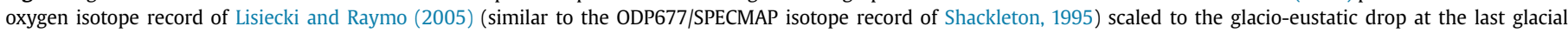

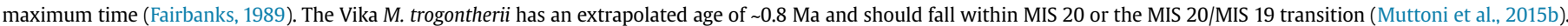

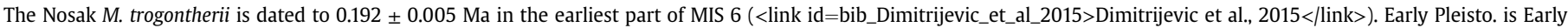
Pleistocene; LP\&H is Late Pleistocene and Holocene.

derives entirely from the mammal assemblage included in the Pirro karst infill that is tentatively placed in reference mammal biozonations to sometime after the Tasso faunal unit, attributed to the Olduvai, and before the Colle Curti faunal unit, attributed to the base of the Jaramillo (e.g., Gliozzi et al., 1997; Masini and Sala,
2007). As stressed elsewhere (e.g., Muttoni et al., 2014), the Galerian Colle Curti faunal unit was magnetostratigraphically tied in the Colle Curti type section in central Italy to the base of the Jaramillo where, however, there is strong indication of diagenetic magnetic overprinting (Coltorti et al., 1998). Indeed, elements of 


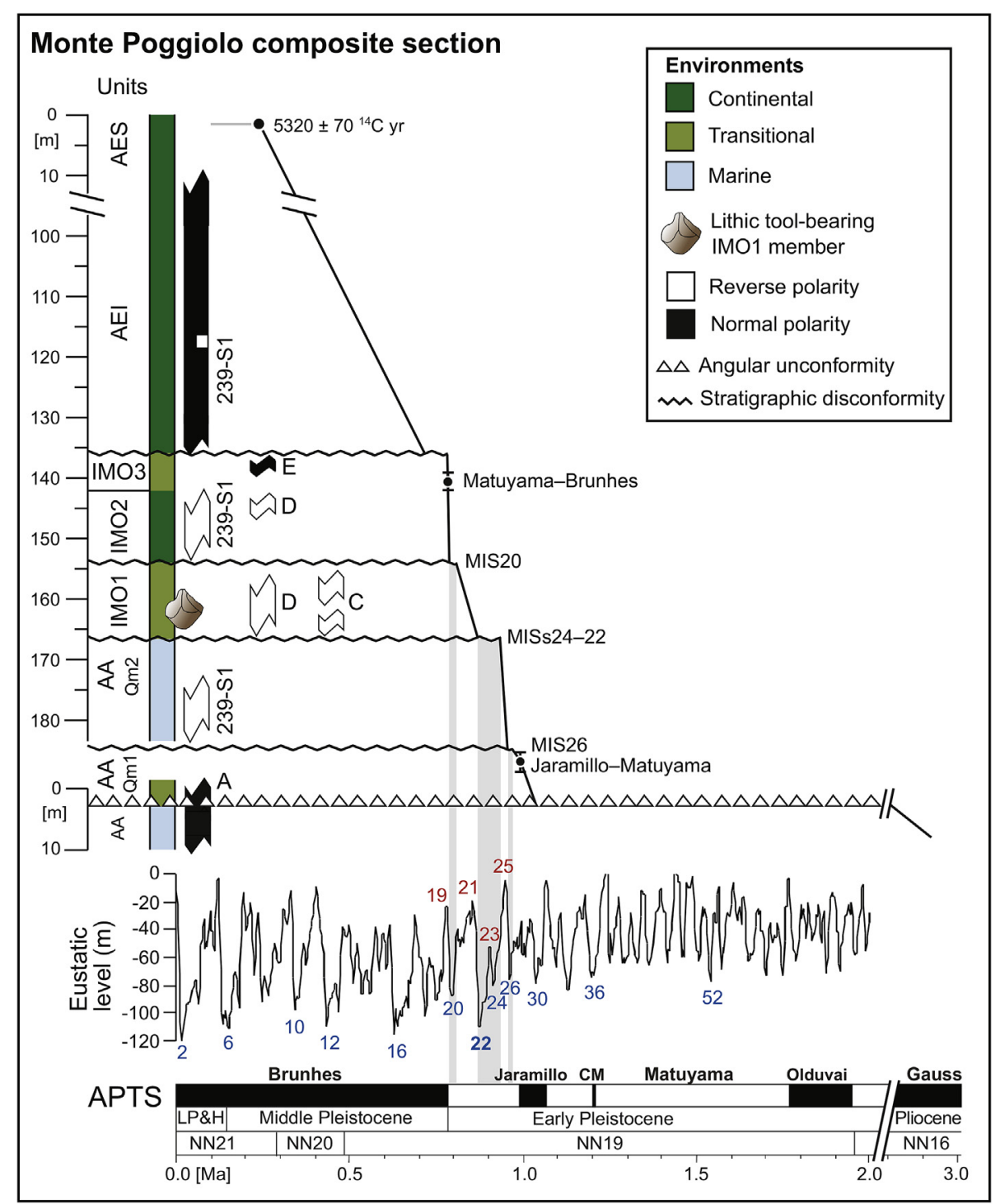

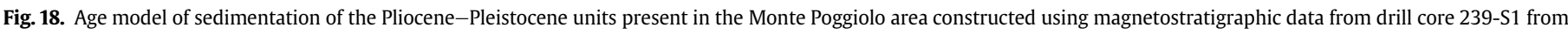

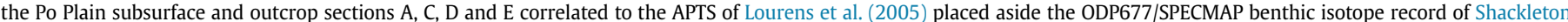

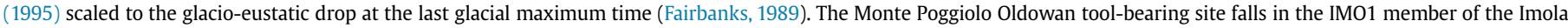
Sands, dated to MIS 21 at $0.85 \mathrm{Ma}$ (Muttoni et al., 2011). LP\&H is Late Pleistocene and Holocene; CM is Cobb Mt. subchron.

the Colle Curti faunal unit are present in the Arda River section from northern Italy in levels magnetostratigraphically dated to $\sim 0.99 \mathrm{Ma}$ at the Jaramillo-Matuyama boundary (Monesi et al., 2016) (Fig. 11). Hence, the chronology of the Colle Curti faunal unit is still unresolved within the late Matuyama, as is the chronology of the Pirro faunal unit that supposedly predates it. Also uncertain is the chronology of the Villafranchian Tasso faunal unit that was defined on specimens whose stratigraphic position in the Upper Valdarno continental sequence of central Italy had to be reconstructed from museum descriptions and tentatively traced onto a subsequent magnetostratigraphic profile to levels close to the top of the Olduvai (Napoleone et al., 2003) at $1.78 \mathrm{Ma}$.

Recently, the presence at Pirro Nord-13 of the arvicolid Allophaiomys ruffoi was utilized in support of the proposed 1.6-1.3 Ma age (López-García et al., 2015). A. ruffoi is considered a precursor of A. lavocati, and because this latter taxon was found at Sima del Elefante (as well as at Barranco León-D and Fuentenueva-3 in the Guadix-Baza Basin of southern Spain) in purported pre-Jaramillo levels, an age in excess of 1 Ma for Pirro Nord-13 was inferred
(López-García et al., 2015). It should be recalled however that the Jaramillo was never found in any of these localities, that the published cosmogenic burial ages for Sima del Elefante are associated with large formal uncertainties of up to $\sim 600 \mathrm{kyr}$ (at $2 \sigma$ level), and that the vole clock dating method based on the assumption of a gradual and regular change in enamel differentiation as proposed by López-García et al. (2015) has been severely questioned (Martin, 2014; Muttoni et al., 2015a).

Indeed, no direct physical evidence is available in support of the age attribution of 1.6-1.3 Ma proposed by Pavia et al. (2012) other than reverse polarity magnetizations indicating that the Pirro karst infill was deposited before $0.78 \mathrm{Ma}$ sometime during the Matuyama (Muttoni et al., 2014, 2015a). Considering the complex physiography of the Italian peninsula, we also wonder if Pirro Nord could represent a relict latest Villafranchian locality that may have temporarily survived the already ongoing diffusion of Galerian mammal immigrants. Alternatively, if the lithic tools from Pirro Nord can eventually be confirmed to be significantly older than the main Galerian turnover, we will need to reconsider the migration 


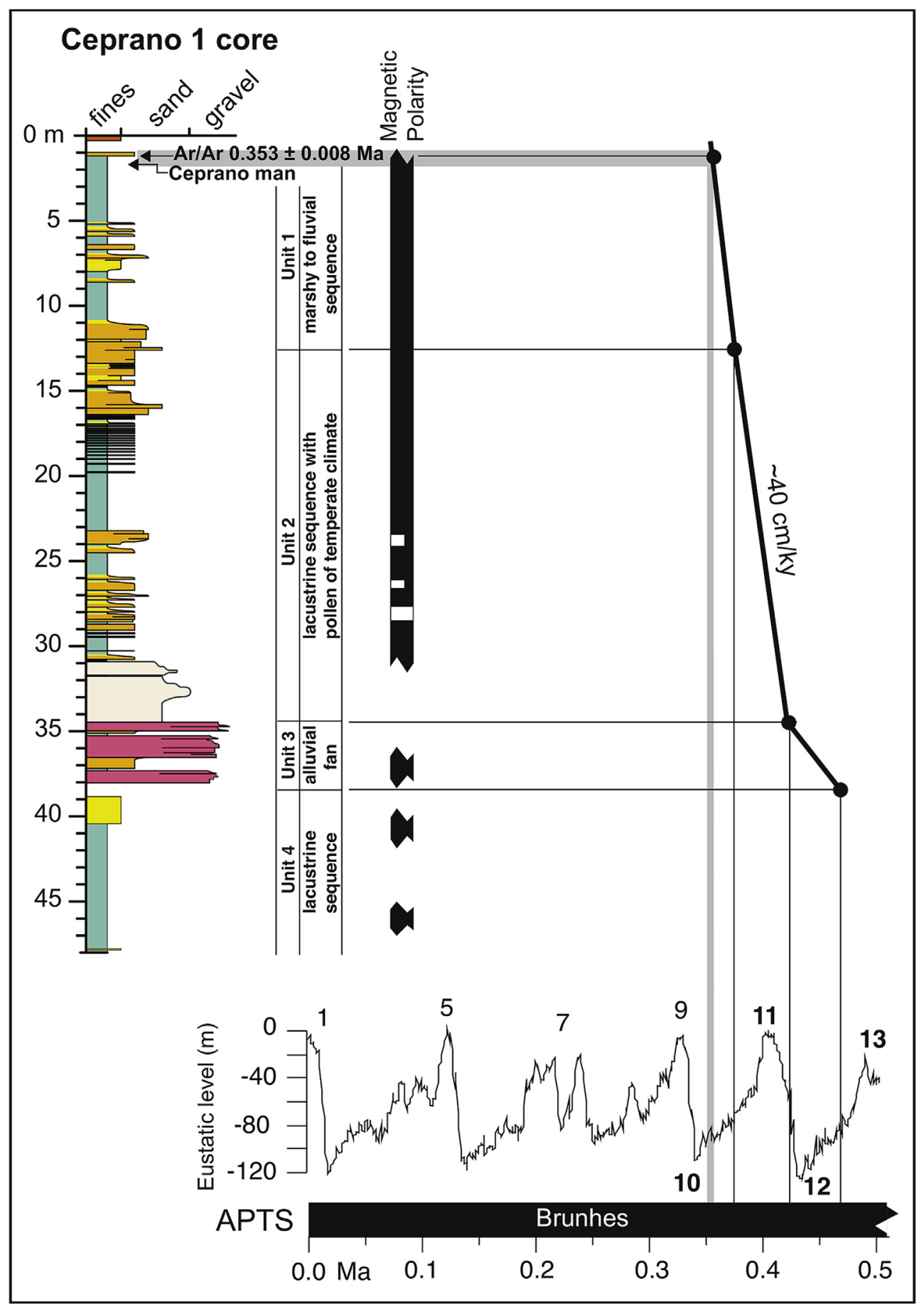

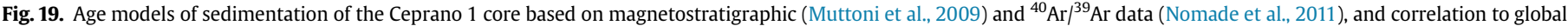

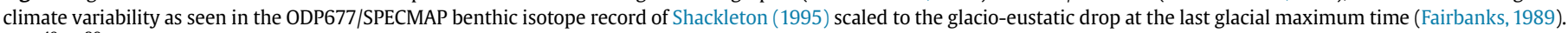
The ${ }^{40} \mathrm{Ar} /{ }^{39} \mathrm{Ar}$ dating yielded an age of $353 \pm 8$ ka for the Ceprano cranium (Nomade et al., 2011).

hypothesis to explain why and when hominins first immigrated into southern Europe.

\subsubsection{Le Vallonnet, France}

The Le Vallonnet cave in southern France (Fig. 1) deserves particular mention because it is frequently attributed to the Jaramillo (see for example Toro-Moyano et al., 2013), evidence of which is, however, very elusive. The cave is the repository of a $\sim 2 \mathrm{~m}$ thick sequence consisting of, from base to top, a lower calcitic flowstone (Complex I), beach sands (Complex II), sands, clays and silts with faunal and lithic remains (Complex III), an upper flowstone (Complex IV), and colluvium (Complex V) (Michel et al., 2017). The top of the lower flowstone and the base of the upper flowstone yielded ESR ages of $1.37 \pm 0.12 \mathrm{Ma}$ and $0.91 \pm 0.06 \mathrm{Ma}$, respectively (Yokoyama et al., 1988). Yokoyama et al. (1988) also reported normal polarity directions from the tool-bearing Complex III without however providing any supportive data. Michel et al. (2017) generated a new magnetostratigraphy of the cave 
succession augmented by U-Pb dates from the upper and lower flowstones bracketing the tool-bearing Complex III. They found evidence for reverse magnetic polarity in Complex I, normal polarity in Complex III (the intervening Complex II yielded no results), reverse polarity in Complex IV, and normal polarity in Complex V. This magnetostratigraphic sequence was interpreted as a record of the Cobb Mountain subchron in Complex III, and a partial record of the Jaramillo subchron in Complex V. This polarity interpretation was however neither adequately illustrated by means of demagnetization diagrams nor supported by rock-magnetic data able to describe the nature of the magnetic minerals carrying the natural remanence. The striking correlation between stratigraphic units and magnetic polarity (see Fig. 4 in Michel et al., 2017) is per se a strong indication of possible remagnetization processes, related for example to endokarstic fluid circulation. Based on this lack of basic experimental information, we suggest caution in accepting that the tool-bearing Complex III should belong to the Cobb Mountain, the shortest ( $37 \mathrm{kyr}-$ long) and most elusive full polarity subchron of the Pleistocene.

Michel et al (2017, supplementary Table 2) reported also uranium and thorium isotopic compositions from a total of 14 samples (including duplicates): 10 from the lower flowstone of Complex I and 4 from the upper flowstones of Complex IV. Three of these samples were selected for ${ }^{234} \mathrm{U} /{ }^{238} \mathrm{U}$ activity correction to yield a total of six U-Pb dates (two per sample) with relatively high MSWD values and means centered around 1.1-1.2 Ma. No information was however provided on the criteria used for choosing these particular samples, i.e., there is in our opinion no complete account on the true $\mathrm{U}-\mathrm{Pb}$ age variability and inherited $\mathrm{Pb}$ composition of these sediments. Awaiting a more thorough account of these promising but incomplete data, we consider the tool-bearing Complex III as still unconstrained within the (late Early?) Pleistocene.

\subsubsection{Vallparadís and Barranc de la Boella, Catalonia, Spain}

The Vallparadís section near Barcelona (Fig. 1) contains a Jaramillo-Matuyama-Brunhes magnetic polarity record (MadurellMalapeira et al., 2010; Martínez et al., 2010) with purported lithic tools (see Madurell-Malapeira et al., 2012 vs. García et al., 2012) recovered in levels of unit EVT7 located between the top of the Jaramillo (0.99 Ma) and the base of the Brunhes (0.78 Ma) (Fig. 15). Attempts to pin down more precisely the age of these levels with the vole clock method (Martínez et al., 2014) were questioned (Martin, 2014; Muttoni et al., 2015a). However, recently published ESR ages of $0.86 \pm 0.09$ and $0.85 \pm 0.05$ Ma for two of these reverse polarity archeological layers (Duval et al., 2015) confirmed their latest Early Pleistocene age. Unit EVT7 also yielded remains of the Galerian mammal immigrant E. antiquus (Martínez et al., 2010, 2014).

Barranc de la Boella near Tarragona (Fig. 1) consists of a 9 mthick sequence of fluvial-alluvial sediments straddling from unit I at the base to unit VI at the top and studied in four correlative stratigraphic sections (Vallverdú et al., 2014). Convincing paleomagnetic analyses indicate the presence of the Brunhes-Matuyama boundary placed at the base of unit IV (Vallverdú et al., 2014). Lithic assemblages interpreted as Early Acheulean were retrieved in unit II of reverse polarity (Matuyama), which were found distributed around the remains of an adult elephant as to suggest butchering activity (Mosquera et al., 2016). Cosmogenic burial dates from the unit I-II transition and unit II yielded rather scattered minimum ages (obtained assuming infinite burial depth and thus no accumulation of cosmogenic nuclides during burial) comprised between $0.24 \pm 0.03$ Ma and $1.8 \pm 0.15$ with an average (based on five entries excluding the 1.8 and 0.24 Ma dates) of $1.00 \pm 0.068 \mathrm{Ma}$ (Vallverdú et al., 2014). Barranc de la Boella is at present interpreted as the oldest European Early Acheulean site with an estimated age broadly compatible with the EPT (Fig. 15) (Vallverdú et al., 2014).

\subsubsection{Atapuerca, Spain}

At Gran Dolina in Atapuerca (Fig. 1), levels bearing hominin remain-bearing Aurora Stratum have been shown to occur immediately below the Brunhes-Matuyama boundary (Parés and PerezGonzález, 1995, 1999) possibly slightly in excess of 0.9 Ma (Parés et al., 2013) (Fig. 15). A very similar magnetostratigraphic profile from the nearby site of Sima del Elefante convincingly placed evidence of hominins in reverse polarity sediments also just below the Brunhes-Matuyama boundary (Parés et al., 2006). The Jaramillo normal polarity subchron $(0.99-1.07 \mathrm{Ma})$ was not found in these sections (Parés et al., 2006; Carbonell et al., 2008) and this may imply that the archeological levels are no older than the top of the Jaramillo. However, the lack of recovery of the Jaramillo in these sections could also be due to unconformities. Indeed, cosmogenic burial dates at Sima del Elefante seem to indicate that hominin occupation was at around 1.1-1.2 Ma (Carbonell et al., 2008), which would be in the Matuyama prior to the Jaramillo.

The conundrum of whether Sima del Elefante was occupied before or after the Jaramillo is not settled. The reported cosmogenic burial ages when their analytical uncertainties are expressed at the $2 \sigma$ level, which should be the conservative standard in numerical dating (Ludwig and Renne, 2000), are of limited chronological value insofar as they span from 0.9 to $1.54 \mathrm{Ma}$ for hominin level TE9 and from 0.77 to 1.49 Ma for level TE7 immediately below. This uncertainty hampers also the use of the arvicolid Allophaiomys lavocati, found in levels associated with the cosmogenic burial ages of debated error resolution, as a proxy for pre-Jaramillo time intervals, as proposed by Cuenca-Bescós et al. (2013) and applied to the Cal Guardiola (Vallparadís, Spain) section by García et al. (2014) and the Pirro Nord (Italy) karst infill by López-García et al. (2015) (see below and discussion in Muttoni et al., 2015a). The hypothesis yet to be disproven is a post-Jaramillo, pre-Brunhes age, especially in the absence of evidence in any of these sections for the Jaramillo.

\subsubsection{Guadix-Baza Basin, Spain}

The 27 m-thick Solana del Zamborino section from the Guadix-Baza Basin of southern Spain (Fig. 1) yielded Acheulean lithic tools (that are found in Africa as early as $1.76 \mathrm{Ma}$; Lepre et al., 2011) from levels immediately above the Brunhes-Matuyama boundary at a nominal age of $0.77-0.75 \mathrm{Ma}$ (Scott and Gibert, 2009). This age attribution was however questioned by Jiménez-Arenas et al. (2011) who pointed out that the levels of the excavation quarry that provided the tools have not been securely traced onto the polarity reversal sequence. For this and other uncertainties, this site will not be considered further.

The Cúllar section again from the Guadix-Baza Basin in Spain yielded a continuous magnetostratigraphic profile extending from the Olduvai across the Jaramillo into the Brunhes (and the intervening Matuyama), with (generic) lithic tools of the Cúllar Baza-1 site traced to $2 \mathrm{~m}$ above the Brunhes-Matuyama boundary (Gibert et al., 2007) (Fig. 15). These sections do not challenge the migration hypothesis, being largely younger than MIS 22 and the EPT, and provide useful additional information such as the first occurrence in Europe of Acheulean hand-axes (Scott and Gibert, 2009; but see Jiménez-Arenas et al., 2011).

Potential evidence in conflict with the hypothesis came from Barranco León. In this section, of exclusive reverse magnetic polarity (Oms et al., 2000; Toro-Moyano et al., 2013), ESR dating on quartz grains from a stratigraphic interval straddling a human tooth-bearing level seem to indicate that hominins were present in southern Europe as early as $1.43 \pm 0.38 \mathrm{Ma}$ (weighted mean age of three individual ESR dates; Toro-Moyano et al., 2013) (Fig. 15). However, as pointed out in a comment (Muttoni et al., 2013), the 
available literature (Oms et al., 2011) suggests that the sheet-flood sandstone layer that yielded the ESR dates may not be traceable laterally anywhere close to distances of $1 \mathrm{~km}$, which would imply that the transport distance of quartz grains may have been insufficient to reset the ESR clock prior to deposition. Accordingly, Muttoni et al. (2013) proposed that the ESR dates may be too inexact to usefully differentiate between pre- and post-Jaramillo times (Fig. 15), as also appeared to be the case with the chronological interpretation of the microfauna (e.g., Allophaiomys aff. lavocati) based on correlations with poorly dated sections.

The tool-bearing Fuente Nueva-3 section, again from the Guadix-Baza Basin, is characterized by reverse polarity magnetizations attributed to the Matuyama Chron before the Jaramillo, even though the Jaramillo was not found in this or correlative nearby sections (Scott et al., 2007). Physical correlations of strata between Fuente Nueva-3 and the nearby sections of Barranco León, Fuente Nueva-1 and Barranco de Orce of exclusively reverse polarity are ambiguous because the embedding palustrine sediments appear to be laterally discontinuous and difficult to trace (see Figs. 2 and 3 in Scott et al., 2007). Hence, it cannot be excluded that the Jaramillo subchron could in fact lie somewhere below Fuente Nueva-3, which would then result in an age younger than $0.99 \mathrm{Ma}$ (but older than $0.78 \mathrm{Ma}$, the age of the Brunhes-Matuyama boundary, even though it was not found in the section) (Fig. 16).

Estrecho del Quipar (Cueva Negra de Estrecho del Ro Quípar) in the Guadix-Baza Basin yielded Acheulean lithic tools and hominin teeth from a 10 m-thick sequence of fine-grained paleosols infilling a relict weathering cavity (rock shelter) (Scott and Gibert, 2009). Magnetostratigraphic analyses from two sections, encompassing a total of $\sim 6.2 \mathrm{~m}$, indicate the presence of exclusive reverse polarity pertaining to the Matuyama Chron (Scott and Gibert, 2009). Based on the presence of micro-mammals, notably Microtus huescarensis, found at the Huéscar-1 site of the Guadix-Baza Basin within a composite magnetostratigraphic sequence about $10 \mathrm{~m}$ below a polarity reversal interpreted as the Brunhes-Matuyama boundary (Gibert et al., 2007), Scott and Gibert (2009) propose a nominal age of $0.9 \mathrm{Ma}$ for the Estrecho del Quipar lithic tools and hominin remains. However, Jiménez-Arenas et al. (2011) suggested that the Estrecho del Quipar archeological levels come from Middle Pleistocene sedimentary infillings deposited above the reversely magnetized sediments, while Walker et al. (2013) insist that they entirely predate the Brunhes-Matuyama boundary; awaiting a resolution of the debate, this site will not be considered further.

\subsubsection{Sites north of the Alps and the Pyrenees}

Oldowan tool-bearing sites in alluvial deposits of the Massif Central of France (Pont-de-Lavaud, La Terre-des-Sablons; Fig. 1) are associated with ESR dates comprised between $\sim 0.9$ and $\sim 1.1 \mathrm{Ma}$ with relatively large error ranges of up to $\pm 0.12-0.2 \mathrm{Myr}$ (Despriée et al., 2011). These promising ESR ages should in our opinion be tested by independent age estimates such as magnetostratigraphy.

In the absence of convincing evidence of Untermassfeld as a Lower Paleolithic site (García et al., 2013 vs. Baales, 2014 vs. Landeck and García, 2015), the northernmost tool-bearing site in Europe is Happisburgh in the U.K. (Parfitt et al., 2010). (Fig. 1). There the sediments are characterized by reverse magnetic polarity attributed, in conjunction with mammal biostratigraphic considerations, to the late Matuyama after the Jaramillo and before the Brunhes (neither of which was found), that is to say, to a time interval comprised between 0.99 and $0.78 \mathrm{Ma}$ and possibly correlated to the MIS 22/21 transition at $2.85 \mathrm{Ma}$ (Fig. 15).

\section{Discussion}

Two different intellectual traditions have addressed the issue of the chronology of early hominin presence in Europe. Advocates of a long chronology (e.g., Carbonell et al., 1995, 2008; Pavia et al., 2012; Toro-Moyano et al., 2013; García et al., 2014) propose that southern Europe (e.g., Spain, Italy) was inhabited well before $1 \mathrm{Ma}$ (and as early as 1.6-1.3 Ma; Pavia et al., 2012) during the pre-Jaramillo but post-Olduvai portion of the Matuyama reverse geomagnetic polarity chron, hence sensibly reducing the gap with the earliest dates claimed for Asia, for example at Dmanisi in Georgia ( 1.85-1.78 Ma; Ferring et al., 2011). Proponents of a short chronology (e.g., Dennell and Roebroeks, 1996; Roebroeks, 2001) claim instead that while southern Europe was inhabited already in the late Early Pleistocene at around $1 \mathrm{Ma}$ (e.g., Carbonell et al., 1995), the boreal zone of northern Europe was uninhabited until the Middle Pleistocene, or up to a million years after hominins first appeared in Asia, although recent findings at Happisburgh document hominin presence in the U.K. at the end of the Early Pleistocene (Parfitt et al., 2010).

According to our preferred chronology, which is 'neither too short nor too long' relative to these standard chronologies from the literature, Europe was first inhabited in the late Early Pleistocene during the EPT, possibly during the waning stages of MIS 22 and the ensuing MIS 22/21 transition at $\sim 0.9-85$ Ma (Fig. 20; see also Fig. 13). This revised chronology pushes to an older age limit of $\sim 0.9$ Ma for the classic long chronology of earliest colonization of southern Europe, and tends to align it with the earliest colonization of northern Europe. Acknowledging that small age differences between sites in southeastern Europe (e.g., Kozarnika, Bulgaria), western Europe (e.g., Atapuerca, Spain), and northern Europe (e.g., Happisburgh, U.K.) could exist, it seems to us that the available numerical age methods indicate that virtually the entire European subcontinent, both south and north of the Alps and Pyrenees, was subject to colonization in close temporal contiguity, possibly well within about one eccentricity ( $100 \mathrm{ky})$ climate cycle, during the EPT.

Migrations occurred in the form of expansions of the Galerian food web, to which hominins presumably belonged, through a PoDanube conduit that connected the Gates of Europe (e.g., Turkey, the Levant, Caucasus) with Europe. This conduit opened, meaning that it became terrestrial and ecologically sustainable for Galerian food web expansions, for the first time during the EPT (Fig. 20; see also Fig. 13). During this time, expansions occurred preferentially when the landscape was characterized by grasslands with reduced woody cover regarded as particularly favorable to mixed browsergrazer megaherbivores, especially elephantidae, and hominins with them, as for example during the waning stages of MIS 22 and the ensuing MIS 22/21 transition (and also later during the ensuing glacial stages and terminations of the Middle Pleistocene; see Fig. 12). In this respect, the reason why we believe that Europe was substantially uninhabited before the EPT resides in the apparent lack of terrestrial sustainable conduits before the EPT that forestalled African and Asian Galerian herbivores (and hominins) from expanding into Europe.

Occasional migrations could have occurred also beyond the spatio-temporal confines of the Po-Danube ecologic space, regarded as intermittently open only since MIS 22. Ultimately, migrations tend to occur because ecosystems are continuously exploited for food provision. Considering however in unison (i) the existence of a Galerian food web pressing at the Gates of Europe (Asia, the Levant-Africa) before the EPT, (ii) the profound changes imposed to the landscapes by the EPT and MIS 22 in particular, and (iii) the (still fluid) timing of earliest main peopling of Europe, our Galerian migration model was built as an alternative to those hypotheses, according to which events just happen and there is no necessity of linking surrounding elements in a common scenario.

Using the concept of an expanding food web to link the 


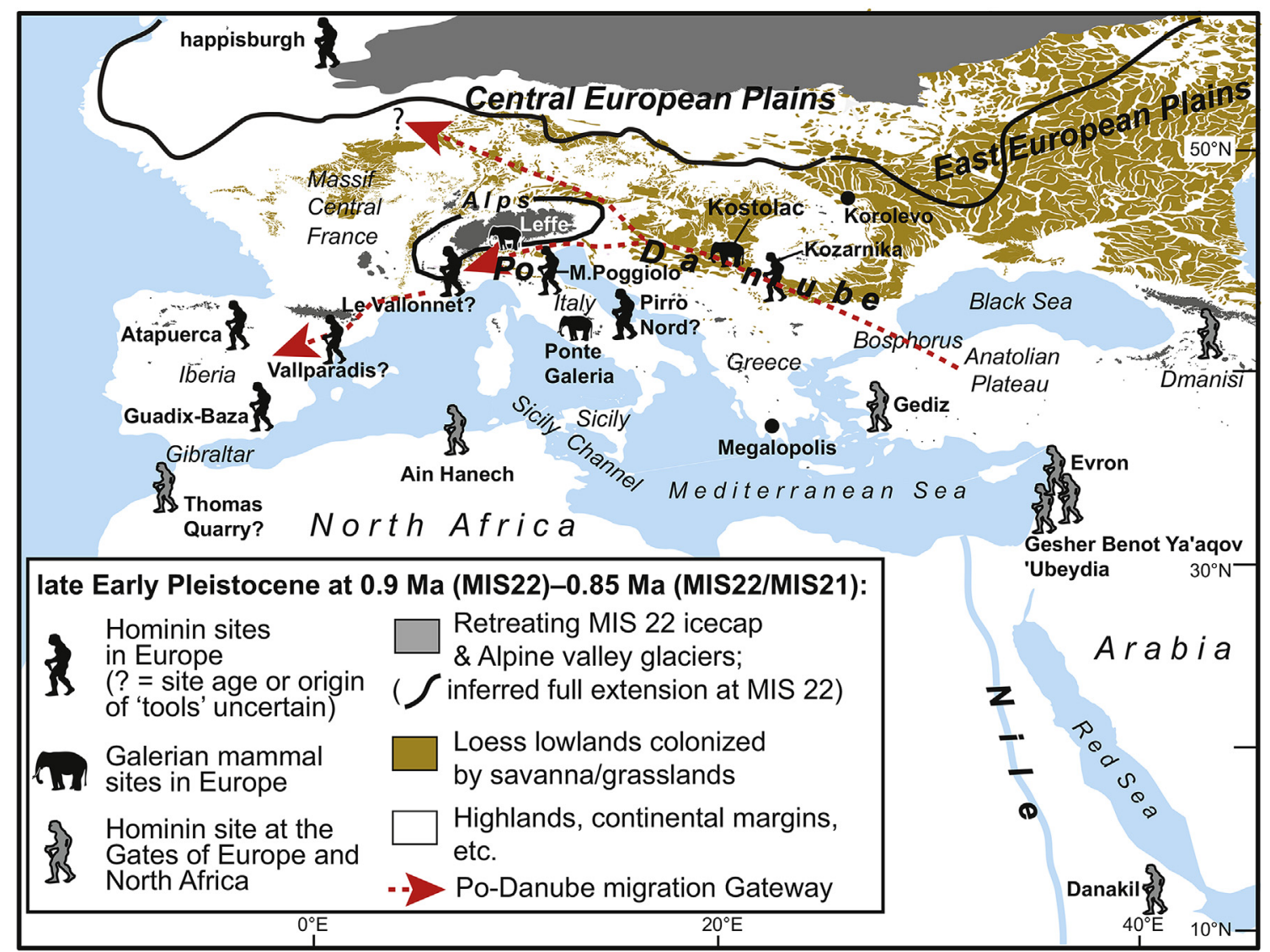

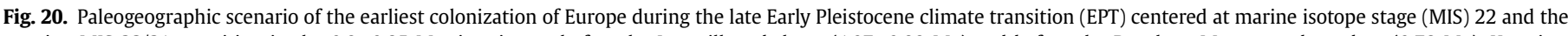

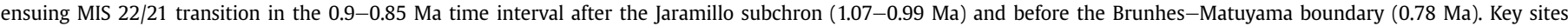

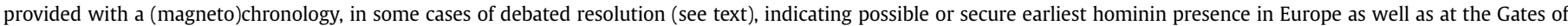

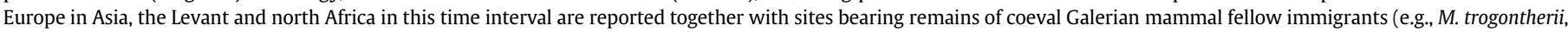

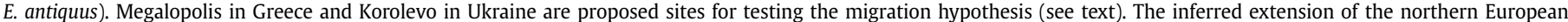

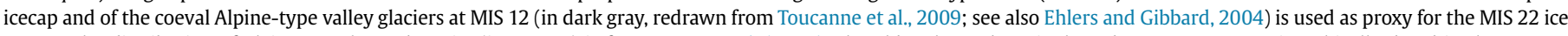

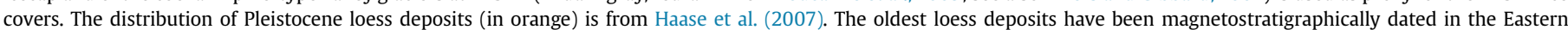

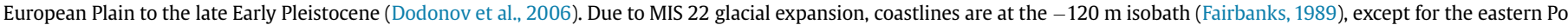
Valley-Adriatic Sea (Kent et al., 2002; Scardia et al., 2012).

migrations of hominins with large herbivores inevitably makes the crossing of extended waterways (e.g., Gibraltar Strait, Sicily Channel) extremely unlikely. Instead, exploiting the Po-Danube conduit for migrations would have implied the crossing of only one limited waterway - the Bosphorus - which may have been at least intermittently emergent during the Pleistocene (Ryan et al., 2003). In addition, the Po-Danube conduit offers the advantage of being equally operative in case hominins came accompanying E. antiquus from Africa via the Levant or M. trogontherii from Asia (Fig. 20; see also Fig. 13). Finally, a terrestrial conduit would be able to sustain gene flow, avoiding biotic isolation and speciation.

The tight temporal coupling of the opening of the Po-Danube conduit and the Galerian mammal turnover in Europe represents one of the founding pillars of our hypothesis. Palombo and Mussi (2006) already suggested that hominins first inhabited the Italian peninsula in close temporal contiguity with the renovated Galerian mammal assemblage and speculated that such early colonization occurred because the Galerian turnover allowed 'a primate of limited physical strength' to expand into the Italian landscape without being threatened by (declining) 'mighty predators' such as Pachycrocuta, not to mention others that hominins were well acquainted since the dawn of their African evolution. Similar conclusions were reached by van der Made (2013) who postulated that
'Human dispersal into Western Europe was probably related to environmental change as detected in the fossil record of large mammals. The dispersal of various species of large mammals, including bison and possibly E. altidens, suggests a temporal extension of open habitats towards the West, which may have allowed humans to spread into the open environments of southwestern Europe.'

Finally, the migration hypothesis bears striking similarities with the dispersal in Europe of anatomically modern humans. They were present in Morocco at $300 \mathrm{ka}$, in the Levant at 120-80 ka (Shea, 2003) during MIS 5, but only considerably later in Europe at around 45-41 ka (Mellars, 2006; Higham et al., 2011; Benazzi et al., 2011) during the (subdued) MIS 3 interstadial (van Meerbeeck et al., 2009). Migrations from the Levant into Europe are proposed to have occurred through a Danube terrestrial conduit (e.g., Conard and Bolus, 2003; Mellars, 2004, 2006). The retarded entrance in Europe is commonly attributed to various causes ultimately linked to challenges of adapting to colder European climates (Shea, 2003), for example, glacial MIS 4 at $\sim 70$ ka (Timmermann and Friedrich, 2016). In that respect, subdued MIS 3 with relatively low sealevel seems to represent the first exploitable window of migration into the Danube terrestrial conduit that was at that time characterized by relatively low values of arboreal pollen (contracted tree populations) as revealed by the pollen record of 
Tenaghi Philippon (Tzedakis et al., 2006).

\section{Conclusions}

The migration hypothesis offers an integrated view of hominin colonization of the European subcontinent that is testable and is subject to refutation by finding hominin sites in Europe with age attributions robustly constrained to the pre-EPT, or in magnetochronological terms, the pre-Jaramillo ( $>1 \mathrm{Ma}$ ). The Jaramillo subchron has thus achieved the status of marker datum useful to separate the long ( $>1 \mathrm{Ma}$ ) from the short ( $<1 \mathrm{Ma}$ ) chronology of earliest peopling of Europe. Whereas there are now many hominin sites with a demonstrable record of the late Matuyama and even the Brunhes-Matuyama boundary, those with a Jaramillo subchron remain exceptionally rare in Europe (see also Muttoni et al., 2015a). In addition, we believe that any presently claimed sites of preJaramillo age (e.g., Carbonell et al., 2008; Pavia et al., 2012; ToroMoyano et al., 2013; see also Muttoni et al., 2015a) rely on relatively unproven techniques and need to be better constrained chronologically. Importantly, claims of pre-Jaramillo age sites should also be contextualized environmentally and ecologically within the Pleistocene climate variability of greater Europe to assess what were - if any - the ecological forces that allowed hominins to migrate into Europe before the EPT - if they did during times of no particular climatic or ecologic transition.

The regional horizon marking the late Early Pleistocene climate transition ('R surface' and its equivalents) could represent a prime target for surveys in search of additional sites in Europe with mammal immigrants from Asia and Africa possibly including early hominins. In that respect, two potential sites are offered for further testing of the hypothesis: Korolevo in Ukraine and Megalopolis in Greece (Fig. 20). Korolevo consists of a loess-paleosol sequence apparently starting close to the Brunhes-Matuyama boundary (albeit no information on the analytical procedures used to obtain the polarity stratigraphy was reported) and containing Oldowan tools presumably coming from levels in the lower part of the succession (Stepanchuk et al., 2010; Koulakovska et al., 2010). The Megalopolis Basin yielded a human tooth (Harvati et al., 2009; Tourloukis and Karkanas, 2012) from stratigraphic levels of uncertain position relative to the Brunhes-Matuyama boundary (van Vught, 2000).

As of now, there is in our opinion no robust evidence of hominin presence in Europe of pre-Jaramillo age and no obvious ecological driving forces or exceptional environmental circumstances that could explain hominin migrations into Europe in the Early Pleistocene prior to the EPT. Instead, all evidence seems to support or not contradict an earliest stable occupation of Europe starting at $\sim 0.9$ Ma during the EPT. The Road from Jaramillo is short and winding but very promising.

\section{Acknowledgements}

GM would like to thank the Rector of the University of Milan for financial support (Fondo Scavi Archeologici 2015). DVK would like to thank Lamont-Doherty Earth Observatory for support of the Paleomagnetics Lab and the Board of Governors Professorship of Rutgers University for financial support. LDEO Contribution \#0000.

\section{References}

Albianelli, A., Napoleone, G., 2004. Magnetostratigraphy of the Homo-Bearing Pleistocene Dandiero basin (Danakil depression, Eritrea). Riv. Ital. Paleontol. Stratigr. 110, 35-44.

Antón, S.C., Potts, R., Aiello, L.C., 2014. Evolution of early Homo: an integrated biological perspective. Science 345. https://doi.org/10.1126/science.1236828, 45-45.
Arzarello, M., Pavia, G., Peretto, C., Petronio, C., Sardella, R., 2012. Evidence of an early Pleistocene hominin presence at Pirro Nord (Apricena, Foggia, southern Italy): P13 site. Quat. Int. 267, 56-61. https://doi.org/10.1016/ j.quaint.2011.01.042.

Ascenzi, A., Biddittu, I., Cassoli, P., Segre, A.G., Segre Naldini, E., 1996. A calvarium of late Homo erectus from Ceprano, Italy. J. Hum. Evol. 31, 409-423.

Ascenzi, A., Mallegni, F., Manzi, G., Segre, A.G., Segre Naldini, E., 2000. A re-appraisal of Ceprano calvaria affinities with Homo erectus, after the new reconstruction. J. Hum. Evol. 39, 443-450.

Ascenzi, A., Segre, A.G., 1997. Discovery of a Homo erectus calvarium at Ceprano, Central Italy. L'Anthropologie 35, 241-246.

Aubry, M.-P., Van Couvering, J.A., Christie-Blick, N., Landing, E., Pratt, B.R., Owen, D.E., Ferrusquia-Villafranca, I., 2009. Terminology of geological time: establishment of a community standard. Stratigraphy 6, 100-105.

Azzaroli, A., 1983. Quaternary mammals and the "End-Villafranchian" dispersal event - a turning point in the history of Eurasia. Palaeogeogr. Palaeoclimatol. Palaeoecol. 44, 117-139.

Baales, M., 2014. Untermassfeld - or the struggle for finding the earliest traces of human occupation in Central Europe: a comment on: "Hominin dispersals from the Jaramillo subchron in central and south-western Europe: Untermassfeld (Germany) and Vallparadís (Spain)" by J. García et al., Quat. Int. 316 (2013), pp. 73-93. Quat. Int. 337, 254-256. https://doi.org/10.1016/j.quaint.2014.05.021.

Backman, J., Raffi, I., Rio, D., Fornaciari, E., 2012. Biozonation and biochronology of Miocene through Pleistocene calcareous nannofossils from low and middle latitudes. Newsletters Stratigr. https://doi.org/10.1127/0078-0421/2012/0022.

Ben-Dor, M., Gopher, A., Hershkovitz, I., Barkai, R., 2011. Man the fat hunter: the demise of Homo erectus and the emergence of a new hominin lineage in the middle Pleistocene (ca. 400 kyr) levant. PLoS One 6 (12), e28689. https:// doi.org/10.1371/journal.pone.0028689.

Benazzi, S., Douka, K., Fornai, C., Bauer, C.C., Kullmer, O., Svoboda, J., Pap, I., Mallegni, F., Bayle, P., Coquerelle, M., Condemi, S., Ronchitelli, A., Harvati, K., Weber, G.W., 2011. Early dispersal of modern humans in Europe and implications for Neanderthal behaviour. Nature 479, 525-528. https://doi.org/10.1038/ nature10617.

Berger, W.H., Bickert, T., Schmidt, H., Wefer, G., 1993. Quaternary oxygen isotope record of pelagic foraminifers: site 806, Ontong Java Plateau. In: Berger, W.H., et al. (Eds.), Proceedings of the Ocean Drilling Program, Scientific Results, vol. 130, pp. 381-395.

Berggren, W.A., Hilgen, F.J., Langereis, C.G., Kent, D.V., Obradovich, J.D., Raffi, I., Raymo, M.E., Shackleton, N.J., 1995. Late Neogene chronology: new perspectives in high-resolution stratigraphy. Geol. Soc. Am. Bull. 107, 1272-1287.

Bolus, M., 2015. Dispersals of early humans: adaptations, frontiers, and new territories. In: Henke, W., Tattersall, I. (Eds.), Handbook of Paleoanthropology, Bd. III. Springer, Berlin, Heidelberg, pp. 2371-2400.

Braun, D., Ron, H., Marco, S., 1991. Magnetostratigraphy of the hominid tool-bearing Erk el Ahmar formation in the northern Dead sea Rift. Isr. J. Earth S. C. 40, $191-197$.

Bruner, E., Manzi, G., 2007. Landmark-based shape analysis of the archaic Homo calvarium from Ceprano (Italy). Am. J. Phys. Anthr. 132, 355-366.

Carbonell, E., Bermúdez de Castro, J.M., Arsuaga, J.L., Diez, J.C., Rosas, A., CuencaBescós, G., Sala, R., Mosquera, M., Rodriguez, X.P., 1995. Lower Pleistocene hominids and artifacts from atapuerca-TD6 (Spain). Science 269, 826-830.

Carbonell, E., Bermúdez de Castro, J.M., Parés, J.M., Perez-Gonzalez, A., CuencaBescós, G., Olle, A., Mosquera, M., Huguet, R., van der Made, J., Rosas, A., Sala, R., Vallverdú, J., García, N., Granger, D.E., Martinon-Torres, M., Rodriguez, X.P., Stock, G.M., Verges, J.M., Allue, E., Burjachs, F., Caceres, I., Canals, A., Benito, A., Diez, C., Lozano, M., Mateos, A., Navazo, M., Rodriguez, J., Rosell, J., Arsuaga, J.L., 2008. The first hominin of Europe. Nature 452, 465-470. https://doi.org/ $10.1038 /$ nature06815.

Coltorti, M., Albianelli, A., Bertini, A., Ficcarelli, G., Laurenzi, M., Napoleone, G., Torre, D., 1998. The Colle Curti mammal site in the Colfiorito area (UmbriaMarchean Apennine, Italy): geomorphology, stratigraphy, paleomagnetism and palynology. Quat. Int. 47-48, 107-116.

Coltorti, M., Féraud, G., Marzoli, A., Peretto, C., Ton-That, T., Voinchet, P., Bahain, J.-J., Minelli, A., Hohenstein, U., 2005. New ${ }^{40} \mathrm{Ar} /{ }^{39} \mathrm{Ar}$, stratigraphic and palaeoclimatic data on the Isernia la Pineta Lower Palaeolithic Site, Molise, Italy. Quat. Int. 131, 11-22. https://doi.org/10.1016/j.quaint.2004.07.004.

Conard, N.J., Bolus, M., 2003. Radiocarbon dating the appearance of modern humans and timing of cultural innovations in Europe: new results and new challenges. J. Hum. Evol. 44 (3), 331-371.

Cuenca-Bescós, G., Melero-Rubio, M., Rofes, J., Martínez, I., Arsuaga, J.L., Blain, H.-A., López-García, J.M., Carbonell, E., Bermúdez de Castro, J.M., 2011. The EarlyMiddle Pleistocene environmental and climatic change and the human expansion in Western Europe: a case study with small vertebrates (Gran Dolina, Atapuerca, Spain). J. Hum. Evol. 60 (4), 481-491.

Cuenca-Bescós, G., Rofes, J., López-García, J.M., Blain, H.-A., Rabal-Garcés, R., Sauqué, V., Arsuaga, J.L., Bermúdez de Castro, J.M., Carbonell, E., 2013. The small mammals of Sima del Elefante (Atapuerca, Spain) and the first entrance of Homo in Western Europe. Quat. Int. 295, 28-35. https://doi.org/10.1016/ j.quaint.2011.12.012.

de Beaulieu, J.-L., Andrieu-Ponel, V., Cheddadi, R., Guiter, F., Ravazzi, C., Reille, M., Rossi, S., 2006. Apport des longues séquences lacustres à la connaissance des variations des climats et des paysages pléistocènes. C. R. Palevol 5, 65-72. https://doi.org/10.1016/j.crpv.2005.11.016.

de Beaulieu, J.-L., Tzedakis, P.C., Andrieu-Ponel, V., Guiter, F., 2013. Pollen records, 
late Pleistocene, middle and late Pleistocene in southern Europe. In: Elias, S.A. (Ed.), Encyclopedia of Quaternary Science, second ed., pp. 63-71.

Dennell, R.W., Roebroeks, W., 1996. The earliest colonization of Europe: the short chronology revisited. Antiquity 70, 535-542.

Derricourt, R., 2005. Getting "out of Africa": sea crossings, land crossings and culture in the hominin migrations. J. World Prehistory 19, 119-132.

Despriée, J., Voinchet, P., Tissoux, H., Bahain, J.-J., Falguères, C., Courcimault, G., Dépont, J., Moncel, M.-H., Robin, S., Arzarello, M., Sala, R., Marquer, L., Messager, E., Puaud, S., Abdessadok, S., 2011. Lower and middle Pleistocene human settlements recorded in fluvial deposits of the middle Loire river basin, centre region, France. Quat. Sci. Rev. 30 (11-12), 1474-1485. https://doi.org/ 10.1016/j.quascirev.2011.02.011.

Dimitrijević, V., Mrdjić, N., Korač, M., Chu, S., Kostić, D., Jovičić, M., Blackwell, B.A.B., 2015. The latest steppe mammoths (Mammuthus trogontherii (pohlig)) and associated fauna on the late middle Pleistocene steppe at Nosak, Kostolac basin, northeastern Serbia. Quat. Int. 379, 14-27. https://doi.org/10.1016/ j.quaint.2015.06.025.

Dodonov, A.E., Zhou, L.P., Markova, A.K., Tchepalyga, A.L., Trubikhin, V.M., Aleksandrovski, A.L., Simakova, A.N., 2006. Middle-upper Pleistocene bioclimatic and magnetic records of the northern black sea coastal area. Quat. Int. 149, 44-54. https://doi.org/10.1016/j.quaint.2005.11.017.

Domínguez-Rodrigo, M., 2002. Hunting and scavenging by early humans: the state of the debate. J. World Prehistory 16 (1), 1-54.

Duval, M., Bahain, J.-J., Falguères, C., Garriga, J.G., 2015. Revisiting the ESR chronology of the early Pleistocene hominin occupation at Vallparadís (Barcelona, Spain). Quat. Int. 389, 213-223. https://doi.org/10.1016/j.quaint.2014.08.054.

Quaternary Glaciations - Extent and Chronology, Part I: Europe. In: Ehlers, J., Gibbard, P.L. (Eds.), 2004. Developments in Quaternary Science, 2. Elsevier, Amsterdam, 475 pp.

El Kadiri, K., de Galdeano, C.S., Pedrera, A., Chalouan, A., Galindo-Zaldívar, J., Julià, R., Akil, M., Hlila, R., Ahmamou, M., 2010. Eustatic and tectonic controls on Quaternary Ras Leona marine terraces (Strait of Gibraltar, northern Morocco). Quat. Res. 74, 277-288.

ENI, 1972. Acque Dolci Sotterranee. ENI, Roma, 914 pp.

Fairbanks, R.G., 1989. A 17,000-year glacio-eustatic sea level record: influence of glacial melting rates on the Younger Dryas event and deep-ocean circulation. Nature 342, 637-642.

Falguères, C., 2003. ESR dating and the human evolution: contribution to the chronology of the earliest humans in Europe. Quat. Sci. Rev. 22, 1345-1351. https://doi.org/10.1016/S0277-3791(03)00047-7.

Ferring, C.R., Oms, O., Agustì, J., Berna, F., Nioradze, M., Shelia, T., Tappen, M., Vekua, A., Zhvania, D., Lordkipanidze, D., 2011. Earliest human occupations at Dmanisi (Georgian Caucasus) dated to 1.85-1.78 Ma. Proc. Nat. Acad. Sci. 108, 10432-10436. https://doi.org/10.1073/pnas.1106638108/-/DCSupplemental/ pnas.201106638SI.pdf.

Franzen, J.L., Gliozzi, E., Jellinek, T., Scholger, R., Weidenfeller, M., 2000. Die spätaltpleistozäne Fossillagerstätte Dorn-Dürkheim 3 und ihre Bedeutung für die Rekonstruktion der Entwicklung des rheinischen Flußsystems. Senckenberg. lethaea 80, 305-353.

Gábris, G., Nádor, A., 2007. Long-term fluvial archives in Hungary: response of the Danube and Tisza rivers to tectonic movements and climatic changes during the Quaternary: a review and new synthesis. Quat. Sci. Rev. 26, 2758-2782.

Gagnepain, J., Laurent, M., Bahain, J.-J., Falguères, C., Hedley, I.G., Peretto, C., Wagner, J.-J., Yokoyama, Y., 1998. Synthese des donnes paleomagnetiques et radiochronologiques du site de Ca' Belvedere di Monte Poggiolo (Romagne, Italie) et de son environment geologique. Acts XIII Congr. UISP 6, 877-888.

García, J., Martínez, K., Carbonell, E., Agustí, J., Burjachs, F., 2012. Defending the early human occupation of Vallparadís (Barcelona, Iberian Peninsula): a reply to Madurell-Malapeira et al. (2012). J. Hum. Evol. 63, 568-575.

García, J., Landeck, G., Martínez, K., Carbonell, E., 2013. Hominin dispersals from the Jaramillo subchron in central and South-western Europe: Untermassfeld (Germany) and Vallparadís (Spain). Quat. Int. 316, 73-93.

García, J., Martínez, K., Cuenca-Bescós, G., Carbonell, E., 2014. Human occupation of Iberia prior to the Jaramillo magnetochron (> 1.07 Myr). Quat. Sci. Rev. 98, 84-99.

Gaudzinski, S., Turner, E., Anzidei, A., Àlvarez-Fernández, E., Arroyo-Cabrales, J., Cinq-Mars, J., Dobosi, V., Hannus, A., Johnson, E., Münzel, S., 2005. The use of Proboscidean remains in every-day Palaeolithic life. Quat. Int. 126, 179-194.

Geraads, D., 2010. Biochronologie mammalienne du Quaternaire du Maroc atlantique, dans son cadre régional. L'Anthropologie 114, 324-340.

Ghielmi, M., Minervini, M., Nini, C., Rogledi, S., Rossi, M., Vignolo, A., 2010. Sedimentary and tectonic evolution in the eastern Po-Plain and northern Adriatic sea area from Messinian to middle Pleistocene (Italy). Rend. Fis. Acc. Lincei 21, 131-166.

Gibbard, P.L., Head, M.J., Walker, M.J.C., 2010. Formal ratification of the quaternary system/period and the Pleistocene series/epoch with a base at $2.58 \mathrm{Ma}$. J. Quat. Sci. 25, 96-102. https://doi.org/10.1002/jqs.1338.

Gibert, L., Scott, G.R., Martin, R.A., Gibert, J., 2007. The early to middle Pleistocene boundary in the Baza Basin (Spain). Quat. Sci. Rev. 26, 2067-2089. https:// doi.org/10.1016/j.quascirev.2007.06.012.

Gibert, L., Scott, G.R., Scholz, D., Budsky, A., Ferràndez, C., Ribot, F., Martin, R.A., Lería, M., 2016. Chronology for the cueva Victoria fossil site (SE Spain): evidence for early Pleistocene Afro-Iberian dispersals. J. Hum. Evol. 90, 183-197.

Gliozzi, E., Abbazzi, L., Argenti, P., Azzaroli, A., Caloi, L., Barbato, L., Di Stefano, G., Esu, D., Ficcarelli, G., Girotti, O., Kotsakis, T., Masini, F., Mazza, P.P.A.,
Mezzabotta, C., Palombo, M.R., Petronio, C., Rook, L., Sala, B., Sardella, R., Zanalda, E., Torre, D., 1997. Biochronology of selected mammals, molluscs and ostracods from the Middle Pliocene to the Late Pleistocene in Italy. The state of the art. Riv. It. Pal. Strat. 103, 369-387.

Goren-Inbar, N., Feibel, C.S., Verosub, K.L., Melamed, Y., Kislev, M., Tchernov, E., Saragusti, I., 2000. Pleistocene milestones on the out-of-Africa corridor at Gesher Benot Ya'aqov. Israel. Sci. 289, 944-947.

Granger, D.E., 2006. A review of burial dating methods using ${ }^{26} \mathrm{Al}$ and ${ }^{10} \mathrm{Be}$. Geol. Soc. Am. Spec. Pap. 415, 1-16.

Güleç, E., Howell, F.C., White, T.D., 1999. Dursunlu - a new lower Pleistocene faunal and artifact-bearing locality in southern Anatolia. In: Ullrich, H. (Ed.), Hominid Evolution - Lifestyles and Survival Strategies. Edition Archaea, pp. 349-364.

Güleç, E., White, T.D., Kuhn, S.L., Özer, I., Sağir, M., Yılmaz, H., Howell, F.C., 2009. The lower Pleistocene lithic assemblag from Dursunlu (Konya), central Anatolia, Turkey. Antiquity 83, 11-22.

Gunderson, K.L., Pazzaglia, F.J., Picotti, V., Anastasio, D.J., Kodama, K.P., Rittenour, T., Frankel, K.F., Ponza, A., Berti, C., Negri, A., Sabbatini, A., 2014. Unraveling tectonic and climatic controls on synorogenic growth strata (Northern Apennines, Italy). Geol. Soc. Am. Bull. B30902.1. https://doi.org/10.1130/B30902.1.

Haase, D., Fink, J., Haase, G., Ruske, R., P csi, M., Richter, H., Altermann, M., J ger, K.D., 2007. Loess in Europe - its spatial distribution based on a European loess map, scale 1:2,500,000. Quat. Sci. Rev. 26, 1301-1312. https://doi.org/10.1016/ j.quascirev.2007.02.003.

Harvati, K., Panagopoulou, E., Runnels, C., 2009. The paleoanthropology of Greece. Evol. Anthr. 18, 131-143.

Head, M.J., Gibbard, P.L., 2005. Early-Middle Pleistocene transitions: an overview and recommendation for the defining boundary. In: Head, M.J., Gibbard, P.L. (Eds.), Early-middle Pleistocene Transitions: the Land-ocean Evidence. Geol. Soc., vol. 247. Special Publications, London, pp. 1-18.

Head, M.J., Pillans, B., Farquhar, S.A., 2008. The Early-Middle Pleistocene Transition: characterization and proposed guide for the defining boundary. Episodes 31, 255-259.

Higham, T., Compton, T., Stringer, C.B., Jacobi, R., Shapiro, B., Trinkaus, E., Chandler, B., Gröning, F., Collins, C., Hillson, S., O'Higgins, P., FitzGerald, C., Fagan, M., 2011. The earliest evidence for anatomically modern humans in northwestern Europe. Nature 479, 521-524. https://doi.org/10.1038/nature.

Hodell, D.A., Channell, J.E.T., 2016. Mode transitions in Northern Hemisphere glaciation: co-evolution of millennial and orbital variability in Quaternary climate. Clim. Past. 12, 1805-1828. https://doi.org/10.5194/cp-12-1805-2016.

Hublin, J.-J., Ben-Ncer, A., Bailey, S.E., Freidline, S.E., Neubauer, S., Skinner, M.M., Bergmann, I., Le Cabec, A., Benazzi, S., Harvati, K., Gunz, P., 2017. New fossils from jebel irhoud (Morocco) and the Pan-African origin of Homo sapiens. Nature 546, 289-292.

Jiménez-Arenas, J.M., Santonja, M., Botella, M., Palmqvist, P., 2011. The oldest handaxes in Europe: fact or artefact? J. Archaeol. Sci. 38, 3340-3349. https:// doi.org/10.1016/j.jas.2011.07.020.

Kahlke, R.-D., 2006. Untermassfeld - a late Early Pleistocene (Epivillafranchian) fossil site near Meiningen (Thuringia, Germany) and its position in the development of the European mammal fauna. Br. Archaeol. Rep. Int. Ser. 1578, 144.

Kahlke, R.-D., 2007. Late early Pleistocene European large mammals and the concept of an epivillafranchian biochron. Cour. Forschunginstitut Senckenberg 20, 265-278.

Kahlke, R.-D., García, N., Kostopoulos, D.S., Lacombat, F., Lister, A.M., Mazza, P.P.A., Spassov, N., Titov, V.V., 2011. Western Palaearctic palaeoenvironmental conditions during the Early and early Middle Pleistocene inferred from large mammal communities, and implications for hominin dispersal in Europe. Quat. Sci. Rev. 30, 1368-1395. https://doi.org/10.1016/j.quascirev.2010.07.020.

Kent, D.V., Rio, D., Massari, F., Kukla, G.J., Lanci, L., 2002. Emergence of Venice during the Pleistocene. Quat. Sci. Rev. 21, 1719-1727.

Koulakovska, L., Usik, V., Haesaerts, P., 2010. Early paleolithic of Korolevo site (Transcarpathia, Ukraine). Quat. Int. 223-224, 116-130. https://doi.org/10.1016/ j.quaint.2009.09.031.

Kukla, J., 1970. Correlations between loesses and deep-sea sediments. Geol. Fören. i Stockh. Förh. 92, 148-180.

Laj, C., Channell, J.E.T., 2015. Geomagnetic excursions. In: Kono, M. (Ed.), Treatise on Geophysics, vol. 5. Elsevier, Amsterdam, pp. 373-416. Geomagnetism.

Landeck, G., García, J., 2015. Jaramillo hominin presence at Untermassfeld (Thuringia, Germany)-Or the struggle against the early 20th century "Mauer mandible paradigm": reply to M. Baales (2014). Quat. Int. 355, 169-171. https:// doi.org/10.1016/j.quaint.2014.07.063.

Langereis, C.G., Krijgsman, W., Muttoni, G., Menning, M., 2010. Magnetostratigraphy - concepts, definitions, and applications. Newsl. Stratigr. 43, 207-233.

Larrasoaña, J.C., Roberts, A.P., Rohling, E.J., Winklhofer, M., Wehausen, R., 2003. Three million years of monsoon variability over the northern Sahara. Clim. Dynam 21, 689-698. https://doi.org/10.1007/s00382-003-0355-z.

Larrasoaña, J.C., Roberts, A.P., Rohling, E.J., 2013. Dynamics of green Sahara periods and their role in hominin evolution. PLoS One 8,1-12. https://doi.org/10.1371/ journal.pone.0076514.

Laukhin, S.A., Ronen, A., Pospelova, G.A., Sharonova, Z.V., Ranov, V.A., Burdukiewicz, J.M., Volgina, V.A., Tsatskin, A., 2001. New data on the Geology and geochronology of the lower palaeolithic site Bizat Ruhama in the southern levant. Paléorient 27, 69-80. https://doi.org/10.3406/paleo.2001.4720.

Lebatard, A.-E., Alçiçek, M.C., Rochette, P., Khatib, S., Vialet, A., Boulbes, N., Bourlès, D.L., Demory, F., Guipert, G., Mayda, S., Titov, V.V., Vidal, L., de Lumley, H., 2014. Dating the Homo erectus bearing travertine from Kocabas, 
(Denizli, Turkey) at at least 1.1 Ma. Earth Planet. Sci. Lett. 390, 8-18. https:// doi.org/10.1016/j.epsl.2013.12.031.

Lepre, C.J., Roche, H., Kent, D.V., Harmand, S., Quinn, R.L., Brugal, J.-P., Texier, P.-J. Lenoble, A., Feibel, C.S., 2011. An earlier origin for the Acheulian. Nature 477, 82-85. https://doi.org/10.1038/nature10372.

Leroy, S., Arpe, K., Mikolajewicz, U., 2011. Vegetation context and climatic limits of the Early Pleistocene hominin dispersal in Europe. Quat. Sci. Rev. 30, 1448-1463.

Lisiecki, L.E., Raymo, M.E., 2005. A Pliocene-Pleistocene stack of 57 globally distributed benthic $\delta 180$ records. Paleoceanography 20, PA001071. https:// doi.org/10.1029/2004PA001071.

Lister, A.M., 2004. Chapter IV ecological interactions of elephantids in Pleistocene eurasia: palaeoloxodon and Mammuthus. In: Goren-Inbar, N., Speth, J.D. (Eds.) Human Paleoecology in the Levantine Corridor. Oxbow Books, Park End Piace, Oxford, pp. 53-60.

Lister, A.M., Sher, A.V., 2001. The origin and evolution of the woolly mammoth. Science 294, 1094-1097.

Lister, A.M., Sher, A.V., van Essen, H., Wei, G., 2005. The pattern and process of mammoth evolution in Eurasia. Quat. Int. 126-128, 49-64.

Lister, A.M., Dimitrijević, V., Marković, Z., Knežević, S., Mol, D., 2012. A skeleton of "steppe" mammoth (Mammuthus trogontherii (Pohlig)) from Drmno, near Kostolac, Serbia. Quat. Int. 276-277, 129-144. https://doi.org/10.1016/ j.quaint.2012.03.021.

López-García, J.M., Luzi, E., Berto, C., Peretto, C., Arzarello, M., 2015. Chronological context of the first hominin occurrence in southern Europe: the Allophaiomys ruffoi (Arvicolinae, Rodentia, Mammalia) from Pirro 13 (Pirro Nord, Apulia, southwestern Italy). Quat. Sci. Rev. 107, 260-266. https://doi.org/10.1016/ j.quascirev.2014.10.029.

Lourens, L.J., Hilgen, F.J., Laskar, J., Shackleton, N.J., Wilson, D.S., 2005. The Neogene period. In: Gradstein, F.M., Ogg, J.G., Smith, A.G. (Eds.), A Geologic Time Scale 2004. Cambridge University Press, pp. 409-440.

Ludwig, K.R., Renne, P.R., 2000. Geochronology on the paleoanthropological time scale. Evol. Anthropol. 9, 101-110.

Maddy, D., Schreve, D., Demir, T., Veldkamp, A., Wijbrans, J.R., van Gorp, W., van Hinsbergen, D.J.J., Dekkers, M.J., Scaife, R., Schoorl, J.M., Stemerdink, C., van der Schriek, T., 2015. The earliest securely-dated hominin artefact in Anatolia? Quat Sci. Rev. 109, 68-75. https://doi.org/10.1016/j.quascirev.2014.11.021.

Madurell-Malapeira, J., Minwer-Barakat, R., Alba, D.M., Garcés, M., Gómez, M., Aurell-Garrido, J., Ros-Montoya, S., Moyà-Solà, S., Berástegui, X., 2010. The Vallparadís section (Terrassa, Iberian peninsula) and the latest villafranchian faunas of Europe. Quat. Sci. Rev. 29, 3972-3982. https://doi.org/10.1016/ j.quascirev.2010.09.020.

Madurell-Malapeira, J., Alba, D.M., Minwer-Barakat, R., Aurell-Garrido, J., MoyàSolà, S., 2012. Early human dispersals into the Iberian Peninsula: a comment on Martínez et al. (2010) and García et al. (2011). J. Hum. Evol. 62, 169-173.

Magri, D., 2010. Persistence of tree taxa in Europe and Quaternary climate changes. Quat. Int. 219, 145-151.

Mallegni, F., Carnieri, E., Bisconti, M., Tartarelli, G., Ricci, S., Biddittu, I., Segre, A., 2003. Homo cepranensis sp. nov. and the evolution of African-European Middle Pleistocene hominids. C. R. Palevol. 2, 153-159. https://doi.org/10.1016/S1631 0683(03)00015-0.

Manzi, G., 2004. Human evolution at the Matuyama-Brunhes boundary. Evol. Anthropol. 13, 11-24. https://doi.org/10.1002/evan.10127.

Martin, R.A., 2014. A critique of vole clocks. Quat. Sci. Rev. 94,1-6. https://doi.org/ 10.1016/j.quascirev.2014.03.004

Martínez, K., Garriga, J.G., Carbonell, E., Agustì, J., Bahain, J.-J., Blain, H.-A., Burjachs, F., Caceres, I., Duval, M., Falguères, C., Gómez, M., Huguet, R., 2010. A new lower Pleistocene archeological site in Europe (Vallparadis, Barcelona, Spain). Proc. Nat. Acad. Sci. 107, 5762-5767. https://doi.org/10.1073/ pnas.0913856107.

Martínez, K., García, J., Burjachs, F., Yll, R., Carbonell, E., 2014. Early human occupation of Iberia: the chronological and palaeoclimatic inferences from Vallparadís (Barcelona, Spain). Quat. Sci. Rev. 85, 136-146.

Martínez-Navarro, B., 2010. Early Pleistocene faunas of Eurasia and hominid dispersals. In: Fleagle, J., Shea, J.J., Grine, F., Beiden, A., Leakey, R.E. (Eds.), Out of Africa I: the First Hominin Colonization of Eurasia. Springer, Dordrecht, pp. 207-224.

Masini, F., Sala, B., 2007. Large- and small-mammal distribution patterns and chronostratigraphic boundaries from the Late Pliocene to the Middle Pleistocene of the Italian peninsula. Quat. Int. 160, 43-56. https://doi.org/10.1016/ j.quaint.2006.09.008.

Massari, F., Rio, D., Serandrei Barbero, R., Asioli, A., Capraro, L., Fornaciari, E. Vergerio, P., 2004. The environment of Venice area in the past two million years. Palaeogeogr. Palaeoecol. Palaeoclima 202, 273-308.

Mellars, P., 2004. Neanderthals and the modern human colonization of Europe Nature 432, 461-465.

Mellars, P., 2006. Archeology and the dispersal of modern humans in Europe: deconstructing the "Aurignacian". Evol. Anthropol. 15, 167-182.

Michel, V., Shen, C.C., Woodhead, J., Hu, H.M., Wu, C.C., Moullé, P.É., Khatib, S. Cauche, D., Moncel, M.H., Valensi, P., Chou, Y.M., Gallet, S., Echassoux, A., Orange, F., de Lumley, H., 2017. New dating evidence of the early presence of hominins in Southern Europe. Sci. Rep. 7 (10074), 1-8. https://doi.org/10.1038 s41598-017-10178-4.

Monesi, E., Muttoni, G., Scardia, G., Felletti, F., Bona, F., Sala, B., Tremolada, F. Francou, C., Raineri, G., 2016. Insights on the opening of the Galerian mammal migration pathway from magnetostratigraphy of the Pleistocene marinecontinental transition in the Arda River section (northern Italy). Quat. Res. 86, 220-231. https://doi.org/10.1016/j.yqres.2016.07.006.

Morgan, L.E., Renne, P.R., Kieffer, G., Piperno, M., Gallotti, R., Raynal, J.P., 2012. A chronological framework for a long and persistent archaeological record: Melka Kunture, Ethiopia. J. Hum. Evol. 62, 104-115.

Mosquera, M., Ollé, A., Saladié, P., Cáceres, I., Huguet, R., Rosas, A., Villalaín, J., Carrancho, A., Bourlès, D., Braucher, R., Pineda, A., Vallverdú, J., 2016. The Early Acheulean technology of Barranc de la Boella (Catalonia, Spain). Quat. Int. 393, 95-111.

Muttoni, G., Carcano, C., Garzanti, E., Ghielmi, M., Piccin, A., Pini, R., Rogledi, S., Sciunnach, D., 2003. Onset of major Pleistocene glaciations in the Alps. Geology 31, 989-992.

Muttoni, G., Ravazzi, C., Breda, M., Pini, R., Laj, C., Kissel, C., Mazaud, A., Garzanti, E., 2007. Magnetostratigraphic dating of an intensification of glacial activity in the southern Italian Alps during Marine Isotope Stage 22. Quat. Res. 67, 161-173. https://doi.org/10.1016/j.yqres.2006.07.006.

Muttoni, G., Scardia, G., Kent, D.V., Swisher III, C.C., Manzi, G., 2009. Pleistocene magnetochronology of early hominin sites at Ceprano and Fontana Ranuccio. Italy. Earth Planet. Sci. Lett. 286, 255-268. https://doi.org/10.1016/ j.epsl.2009.06.032.

Muttoni, G., Scardia, G., Kent, D.V., 2010. Human migration into Europe during the late Early Pleistocene climate transition. Palaeogeogr. Palaeoclimatol. Palaeoecol. 296, 79-93. https://doi.org/10.1016/j.palaeo.2010.06.016.

Muttoni, G., Scardia, G., Kent, D.V., Morsiani, E., Tremolada, F., Cremaschi, M., Peretto, C., 2011. First dated human occupation of Italy at $\sim 0.85$ Ma during the late Early Pleistocene climate transition. Earth Planet. Sci. Lett. 307, 241-252. https://doi.org/10.1016/j.epsl.2011.05.025.

Muttoni, G., Scardia, G., Kent, D.V., 2013. A critique of evidence for human occupation of Europe older than the Jaramillo subchron (ca. $1 \mathrm{Ma}$ ): comment on "The oldest human fossil in Europe from Orce (Spain)" by Toro-Moyano et al. (2013). J. Hum. Evol. 65, 746-749. https://doi.org/10.1016/j.jhevol.2013.08.005.

Muttoni, G., Kent, D.V., Scardia, G., Monesi, E., 2014. Migration of hominins with megaherbivores into Europe via the Danube-Po Gateway in the late Matuyama climate revolution. Riv. It. Pal. Strat. 120, 351-365.

Muttoni, G., Kent, D.V., Scardia, G., Martin, R.A., 2015a. Bottleneck at Jaramillo for human migration to Iberia and the rest of Europe? J. Hum. Evol. 80, 187-190. https://doi.org/10.1016/j.jhevol.2014.12.003.

Muttoni, G., Scardia, G., Dimitrijević, V., Kent, D.V., Monesi, E., Mrdjić, N., Korač, M., 2015b. Age of Mammuthus trogontherii from Kostolac, Serbia, and the entry of megaherbivores into Europe during the late Matuyama climate revolution. Quat. Res. 84, 436-447. https://doi.org/10.1016/j.yqres.2015.09.001.

Muttoni, G., Sirakov, N., Guadelli, J.-L., Monesi, E., Kent, D.V., Scardia, G., Zerboni, A., Ferrara, E., 2017. An early Brunhes ( $<0.78 \mathrm{Ma}$ ) age for the Lower Paleolithic toolbearing Kozarnika cave sediments, Bulgaria. Quat. Sci. Rev. 178, 1-13.

Napoleone, G., Albianelli, A., Azzaroli, A., Bertini, A., Magi, M., Mazzini, M., 2003. Calibration of the upper Valdarno basin to the plio-pleistocene for correlating the apennine continental sequences. Il Ouat. 16, 131-166.

Nomade, S., Muttoni, G., Guillou, H., Robin, E., Scardia, G., 2011. First ${ }^{40} \mathrm{Ar} /{ }^{39} \mathrm{Ar}$ age of the Ceprano man (central Italy). Quat. Geochronol. 6, 453-457. https://doi.org/ 10.1016/j.quageo.2011.03.008.

Nomade, S., Pastre, J.-F., Guillou, H., Faure, M., Guérin, C., Delson, E., Debard, E., Voinchet, P., Messager, E., 2014. ${ }^{40} \mathrm{Ar} /{ }^{39} \mathrm{Ar}$ constraints on some French landmark Late Pliocene to Early Pleistocene large mammalian paleofaunas: paleoenvironmental and paleoecological implications. Quat. Geochronol. 21, 2-15. https:// doi.org/10.1016/j.quageo.2012.12.006.

Oms, O., Parés, J.M., Martínez-Navarro, B., Agustì, J., Toro-Moyano, I., MartinezFernandez, G., Turq, A., 2000. Early human occupation of Western Europe: paleomagnetic dates for two paleolithic sites in Spain. Proc. Nat. Acad. Sci. 97, 10666-10670. https://doi.org/10.1073/pnas.180319797.

Oms, O., Anadón, P., Agustì, J., Julià, R., 2011. Geology and chronology of the continental Pleistocene archeological and paleontological sites of the Orce area (Baza basin, Spain). Quat. Int. 243, 33-43. https://doi.org/10.1016/ j.quaint.2011.03.048.

Opdyke, N.D., Lindsay, E.H., Kukla, G.J., 1983. Evidence for earlier date of Ubeidiya, Israel hominid site. Nature 304, 375-375.

Palombo, M.R., Ferretti, M.P., 2005. Elephant fossil record from Italy: knowledge, problems, and perspectives. Quat. Int. 126-128, 107-136. https://doi.org/ 10.1016/j.quaint.2004.04.018.

Palombo, M.R., Mussi, M., 2006. Large mammal guilds at the time of the first human colonization of Europe: the case of the Italian Pleistocene record. Quat. Int. 149, 94-103. https://doi.org/10.1016/j.quaint.2005.11.022.

Parés, J.M., Pérez-Gonzalez, A., 1995. Paleomagnetic age for homind fossils at Atapuerca Archaeological site, Spain. Science 269, 830-832.

Parés, J.M., Perez-Gonzalez, A., 1999. Magnetochronology and stratigraphy at gran Dolina section, Atapuerca (Burgos, Spain). J. Hum. Evol. 37, 325-342.

Parés, J.M., Perez-Gonzalez, A., Rosas, A., Benito, A., Bermúdez de Castro, J.M., Carbonell, E., Huguet, R., 2006. Matuyama-age lithic tools from the Sima del Elefante site, Atapuerca (northern Spain). J. Hum. Evol. 50, 163-169. https:// doi.org/10.1016/j.jhevol.2005.08.011.

Parés, J.M., Arnold, L.J., Duval, M., Demuro, M., Perez-Gonzalez, A., Bermúdez de Castro, J.M., Carbonell, E., Arsuaga, J.L., 2013. Reassessing the age of AtapuercaTD6 (Spain): new paleomagnetic results. J. Archaeol. Sci. 40, 4586-4595. https://doi.org/10.1016/j.jas.2013.06.013.

Parés, J.M., Sahnouni, M., van der Made, J., Perez-Gonzalez, A., Harichane, Z., 
Derradji, A.E.K., Medig, M., 2014. Early human settlements in Northern Africa: paleomagnetic evidence from the Aïn Hanech Formation (northeastern Algeria). Quat. Sci. Rev. 99, 203-209. https://doi.org/10.1016/ j.quascirev.2014.06.020.

Parfitt, S.A., Ashton, N.M., Lewis, S.G., Abel, R.L., Coope, G.R., Field, M.H., Gale, R., Hoare, P.G., Larkin, N.R., Lewis, M.D., Karloukovski, V., Maher, B.A., Peglar, S.M., Preece, R.C., Whittaker, J.E., Stringer, C.B., 2010. Early Pleistocene human occupation at the edge of the boreal zone in northwest Europe. Nature 466, 229-233. https://doi.org/10.1038/nature09117.

Pavia, M., Zunino, M., Coltorti, M., Angelone, C., Arzarello, M., Bagnus, C., Bellucci, L., Colombero, S., Marcolini, F., Peretto, C., Petronio, C., Petrucci, M., Pieruccini, P., Sardella, R., Tema, E., Villier, B., Pavia, G., 2012.

Pawłowska, K., 2017. Large mammals affected by hominins: paleogeography of butchering for the european early and middle Pleistocene. Quat. Int. 438, 104-115.

Peretto, C., 2006. The first peopling of southern Europe: the Italian case. C. R. Palevol. 5, 283-290.

Peretto, C., Amore, F.O., Antoniazzi, A., Antoniazzi, A., Bahain, J.-J., Cattani, L., Cavallini, E., Esposito, P., Falguères, C., Gagnepain, J., Hedley, I.G., Pugliese, M., Renault-Miskovsky, J., Sozzi, M., Ungaro, S., Vannucci, S., Verges, J.M., Wagner, J.J., Yokoyama, Y., 1998. L'industrie lithique de Ca‘ Belvedere di Monte Poggiolo: stratigraphie, matière première, typologie, remontages et traces d'utilisation. L'Anthropologie 102, 343-465.

Peretto, C., Arnaud, J., Moggi-Cecchi, J., Manzi, G., Nomade, S., Pereira, A., Falguères, C., Bahain, J.-J., Grimaud-Hervé, D., Berto, C., Sala, B., Lembo, G., Muttillo, B., Gallotti, R., Thun Hohenstein, U., Vaccaro, C., Coltorti, M., Arzarello, M., 2015. A human deciduous tooth and new 40Ar/39Ar dating results from the middle Pleistocene archaeological site of Isernia La Pineta, southern Italy. PLoS One 10 (19), e0140091. https://doi.org/10.1371/ journal.pone.0140091.

Pillans, B., Naish, T., 2004. Defining the quaternary. Quat. Sci. Rev. 23, 2271-2282.

Popov, V.V., Marinska, M., 2007. An almost one million year long (Early to Late Pleistocene) small mammal succession from the archaeological layers of Kozarnika cave in Northern Bulgaria. Cour. Forschungsinstitut Senckenberg 259, 79-92.

Ravazzi, C., Pini, R., Breda, M., Martinetto, E., Muttoni, G., Chiesa, S., Confortini, F., Egli, R., 2005. The lacustrine deposits of Fornaci di Ranica (late Early Pleistocene, Italian Pre-Alps): stratigraphy, palaeoenvironment and geological evolution. Quat. Int. 131, 35-58.

Raynal, J.P., Sbihi-Alaoui, F.-Z., Mohib, A., El Graoui, M., Lefèvre, D., Texier, J.-P., Geraads, D., Hublin, J.-J., Smith, T., Tafforeau, P.,Zouak, M., Grün, R., Rhodes, E.J. Eggins, S., Daujeard, C., Fernandes, P., Gallotti, R., Hossini, S., Queffelec, A., 2010. Hominid cave at Thomas quarry I (casablanca, Morocco): recent findings and their context. Quat. Int. 223-224, 369-382.

Richter, D., Grün, R., Joannes-Boyau, R., Steele, T.E., Amani, F., Rué, M., Fernandes, P., Raynal, J.-P., Geraads, D., Ben-Ncer, A., Hublin, J.-J., McPherron, S.P., 2017. The age of the hominin fossils from JebelIrhoud, Morocco, and the origins of the Middle Stone Age. Nature 546, 293-296.

Rink, W.J., Bartoll, J., Schwarcz, H.P., Shane, P., Bar-Yosef, O., 2007. Testing the reliability of ESR dating of optically exposed buried quartz sediments. Radiat. Meas. 42, 1618-1626. https://doi.org/10.1016/j.radmeas.2007.09.005.

Rivals, F., Semprebon, G., Lister, A., 2012. An examination of dietary diversity patterns in Pleistocene proboscideans (Mammuthus, Palaeoloxodon, and Mammut) from Europe and North America as revealed by dental microwear. Quat. Int. 255, 188-195.

Rodríguez-Vidal, J., Cáceres, L.M., Finlayson, J.C., Gracia, F.J., Martínez-Aguirre, A., 2004. Neotectonics and shoreline history of the Rock of Gibraltar, southern Iberia. Quat. Sci. Rev. 23, 2017-2029.

Roebroeks, W., 2001. Hominid behaviour and the earliest occupation of Europe: an exploration. J. Hum. Evol. 41, 437-461.

Ron, H., Levi, S., 2001. When did hominids first leave Africa? New high-resolution magnetostratigraphy from the Erk-el-Ahmar Formation, Israel. Geology 29, 887-890.

Ron, H., Porat, N., Ronen, A., Tchernov, E., Horwitz, L.K., 2003. Magnetostratigraphy of the Evron member - implications for the age of the middle acheulian site of Evron quarry. J. Hum. Evol. 44, 633-639. https://doi.org/10.1016/S00472484(03)00043-5.

Ryan, W.B.F., Major, C.O., Lericolais, G., Goldstein, S.L., 2003. Catastrophic flooding in the black sea. Annu. Rev. Earth Planet. Sci. 31, 525-554.

Scardia, G., Muttoni, G., Sciunnach, D., 2006. Subsurface magnetostratigraphy of Pleistocene sediments from the Po Plain (Italy): constraints on rates of sedimentation and rock uplift. Geol. Soc. Am. Bull. 118, 1299-1312. https://doi.org/ 10.1130/B25869.1.

Scardia, G., Donegana, M., Muttoni, G., Ravazzi, C., Vezzoli, G., 2010. Late Matuyama climate forcing on sedimentation at the margin of the southern Alps (Italy). Quat. Sci. Rev. 29, 832-846. https://doi.org/10.1016/j.quascirev.2009.12.002.

Scardia, G., De Franco, R., Muttoni, G., Rogledi, S., Caielli, G., Carcano, C., Sciunnach, D., Piccin, A., 2012. Stratigraphic evidence of a Middle Pleistocene climate-driven flexural uplift in the Alps. Tectonics 31, TC003108. https:// doi.org/10.1029/2012TC003108.

Scardia, G., Festa, A., Monegato, G., Pini, R., Rogledi, S., Tremolada, F., Galadini, F., 2015. Evidence for late Alpine tectonics in the Lake Garda area (northern Italy) and seismogenic implications. Geol. Soc. Am. Bull.127, 113-130. https://doi.org/ 10.1130/B30990.1.

Scott, G.R., Gibert, L., Gibert, J., 2007. Magnetostratigraphy of the Orce region (Baza
Basin), SE Spain: new chronologies for early Pleistocene faunas and hominid occupation sites. Quat. Sci. Rev. 26 (3-4), 415-435.

Scott, G.R., Gibert, L., 2009. The oldest hand-axes in Europe. Nature 461, 82-85. https://doi.org/10.1038/nature08214.

Shackleton, N.J., 1995. New data on the evolution of Pliocene climate variability. In: Vrba, E., Denton, G.H., Partridge, T.C., Burckle, L.H. (Eds.), Paleoclimate and Evolution with Emphasis on Human Origins. Yale University Press, New Haven, pp. $242-248$.

Shackleton, N.J., Opdyke, N.D., 1976. Oxygen-isotope and paleomagnetic stratigraphy of Pacific core V28-239: late Pliocene to latest Pleistocene. Geol. Soc. Am. Mem. 145, 449-464.

Shackleton, N.J., Berger, A., Peltier, W.R., 1990. An alternative astronomical calibration of the lower Pleistocene timescale based on ODP Site 677. Trans. R. Soc. Edinb. Earth Sci. 81, 251-261.

Shea, J.J., 2003. The middle paleolithic of the east Mediterranean Levant. J. World Prehist. 17, 313-394.

Sirakov, N., Guadelli, J.L., Ivanova, S., Sirakova, S., Boudadi-Maligne, M., Dimitrova, I., Ph, F., Ferrier, C., Guadelli, A., Iordanova, D., Iordanova, N., Kovatcheva, M., Krumov, I., Leblanc, J.-C., Miteva, V., Popov, V., Spassov, R., Taneva, S., Tsanova, T., 2010. An ancient continuous human presence in the Balkans and the beginnings of human settlement in western Eurasia: a Lower Pleistocene example of the Lower Palaeolithic levels in Kozarnika cave (North-western Bulgaria). Quat. Int. 223-224, 94-106. https://doi.org/10.1016/j.quaint.2010.02.023.

Stepanchuk, V., Ryzhov, S., Rekovets, L., Matviishina, Z., 2010. The lower palaeolithic of Ukraine: current evidence. Quat. Int. 223, 131-142.

Straus, L.G., 2001. Africa and Iberia in the Pleistocene. Quat. Int. 75, 91-102. https:// doi.org/10.1016/S1040-6182(00)00081-1.

Swisher III, C.C., Curtis, G., Jacob, T., Getty, A., Suprijo, A., 1994. Age of the earliest known hominids in Java, Indonesia. Science 263, 1118-1121.

Tchernov, E., 1992. Dispersal. A suggestion for a common usage of this term. Cour. Forsch. Inst. Senekenb. 153, 21-25.

Timmermann, A., Friedrich, T., 2016. Late Pleistocene climate drivers of early human migration. Nature 538, 92-95.

Toucanne, S., Zaragosi, S., Bourillet, J.F., Gibbard, P.L., Eynaud, F., Giraudeau, J. Turon, J.L., Cremer, M., Cortijo, E., Martinez, P., Rossignol, L., 2009. A 1.2 Ma record of glaciation and fluvial discharge from the West European Atlantic margin. Quat. Sci. Rev. 28, 2974-2981. https://doi.org/10.1016 j.quascirev.2009.08.003.

Toro-Moyano, I., Martínez-Navarro, B., Agustì, J., Souday, C., Bermúdez de Castro, J.M., Martinon-Torres, M., Fajardo, B., Duval, M., Falguères, C., Oms, O., Parés, J.M., Anadón, P., Julià, R., García-Aguilar, J.M., Moigne, A.-M., Espigares, M.P., Ros-Montoya, S., Palmqvist, P., 2013. The oldest human fossil in Europe, from Orce (Spain). J. Hum. Evol. 1-9. https://doi.org/10.1016/ j.jhevol.2013.01.012.

Tourloukis, V., Karkanas, P., 2012. The Middle Pleistocene archaeological record of Greece and the role of the Aegean in hominin dispersals: new data and interpretations. Quat. Sci. Rev. 43,1-15.

Trauth, M.H., Larrasoaña, J.C., Mudelsee, M. 2009. Trends, rhythms and events in Plio-Pleistocene African climate. Quat. Sci. Rev. 28, 399-411.

Tzedakis, P.C., Hooghiemstra, H., Palike, H., 2006. The last 1.35 million years at Tenaghi Philippon: revised chronostratigraphy and long-term vegetation trends. Quat. Sci. Rev. 25, 3416-3430. https://doi.org/10.1016/ j.quascirev.2006.09.002.

Vallverdú, J., Saladié, P., Rosas, A., Huguet, R., Cáceres, I., Mosquera, M., GarcíaTabernero, A. Estalrrich, A., Lozano-Fernández, I., Pineda-Alcalá, A Carrancho, Á., Villalaín, J.J., Bourlès, D., Braucher, R., Lebatard, A., Vilalta, J. Esteban-Nadal, M., Bennàsar, M.L., Bastir, M., López-Polín, L., Ollé, A. Vergés, J.M., Ros-Montoya, S., Martínez-Navarro, B., García, A., Martinell, J. Expósito, I., Burjachs, F., Agustí, J., Carbonell, E., 2014. Age and Date for Early Arrival of the Acheulian in Europe (Barranc de la Boella, la Canonja, Spain). PLoS One 9 (7), e103634.

van der Made, J., 2013. First description of the large mammals from the locality of Penal, and updated faunal lists for the Atapuerca ungulates - Equus altidens, Bison and human dispersal into Western Europe. Quat. Int. 295, 36-47.

van Meerbeeck, C.J., Renssen, H., Roche, D.M., 2009. How did marine isotope stage 3 and last glacial maximum climates differ? - perspectives from equilibrium simulations. Clim. Past. 5, 33-51.

van Vught, N., 2000. Orbital forcing in late Neogene lacustrine basins from the Mediterranean. A magnetostratigraphic and cyclostratigraphic study. Geol Ultrajectina 189, 164.

Vermeersch, P.M., 2006. La vallée du Nil et le Sahara oriental : une population préhistorique fluctuante sous l'effet des variations climatiques. C. R. Palevol. 5, 255-262.

Villa, P., 2001. Early Italy and the colonization of western Europe. Quat. Int. 75, $113-130$.

Walker, M.J., López Martínez, M.V., Carrión-García, J.S., Rodríguez-Estrella, T., SanNicolás-del-Toro, M., Schwenninger, J.-L., López-Jiménez, A., OrtegaRodrigáñez, J., Haber-Uriarte, M., Polo-Camacho, J.-L., García-Torres, J., Campillo-Boj, M., Avilés-Fernández, A., Zack, W., 2013. Cueva Negra del Estrecho del Río Quípar (Murcia, Spain): a late Early Pleistocene hominin site with an "Acheulo-Levalloiso-Mousteroid" Palaeolithic assemblage. Quat. Int. 294, 135-159.

Winguth, C. Wong, H.K., Panin, N., Dinu, C., Georgescu, P., Ungureanu, G. Krugliakov, V.V., Podshuveit, V., 2000. Upper Quaternary water level history and sedimentation in the northwestern Black Sea. Mar. Geol. 167, 127-146. 
Yokoyama, Y., Bibron, R., Falguères, C., 1988. Datation absolue des planchers stalagmitiques de la grotte du Vallonnet à Roquebrune-Cap-Martin (Alpes-Maritimes, France), par la résonance de spin électronique (ESR). L'Anthropologie 92, 429-436.

Zazo, C., Silva, P.G., Goy, J.L., Hillaire-Marcel, C., Ghaleb, B., Lario, J., Bardaji, T. González, A., 1999. Coastal uplift in continental collision plate boundaries: data from the Last Interglacial marine terraces of the Gibraltar Strait area (south Spain). Tectonophysics 301, 95-109.

Zhu, Z.-Y., Dennell, R.W., Huang, W.-W., Wu, Y., Rao, Z.-G., Qiu, S.-F., Xie, J.-B., Liu, W., Fu, S.-Q., Han, J.-W., Zhou, H.-Y., Yang, T.-P.O., Li, H.-M., 2015. New dating of the Homo erectus cranium from Lantian (Gongwangling), China. J. Hum. Evol. 78, 144-157. https://doi.org/10.1016/j.jhevol.2014.10.001. 